UNIVERSIDADE DE SÃO PAULO

FACULDADE DE FILOSOFIA, LETRAS E CIÊNCIAS HUMANAS

DEPARTAMENTO DE GEOGRAFIA

PROGRAMA DE PÓS-GRADUAÇÃO EM GEOGRAFIA HUMANA

\title{
A CONVENÇÃO DE BASILÉIA E O DESTINO DOS RESÍDUOS INDUSTRIAIS NO BRASIL
}

\author{
Luciana Ziglio
}

Dissertação apresentada ao Programa de Pós-graduação em Geografia Humana do Departamento de Geografia da Faculdade de Filosofia, Letras e Ciências Humanas da Universidade de São Paulo, como exigência parcial para obtenção do título de mestre em geografia.

São Paulo, 2005. 


\section{RESUMO}

A Convenção de Basiléia sobre o Controle de Movimentos Transfronteiriços de Resíduos Perigosos e seu Depósito trata-se de um acordo que define mecanismos de organização dos movimentos transfronteiriços de resíduos sólidos e líquidos perigosos e sua disposição final. Os resíduos perigosos são materiais descartados que podem colocar em risco a segurança da vida.A Convenção para atingir seu propósito de existência permite a concessão prévia e explícita de importação e exportação dos resíduos autorizados entre os países que dela participam, de modo a evitar o tráfico ilícito.

O Brasil através do Decreto número 875 de 1993 confirmou sua permanência como integrante da convenção, internalizando assim o documento no país. A partir de então, todo o comércio internacional de resíduos perigosos entre o Brasil e o exterior passou a ser regulamentado. Os resíduos industriais, considerados perigosos constituem, no Brasil, motivo de preocupação das autoridades e órgãos ambientais, seja devido às quantidades que vem sendo geradas, principalmente como resultado da elevada concentração industrial em algumas regiões do país, seja pela carência de instalações e locais adequados para o tratamento e destino final.

Descrever e discutir as dimensões deste documento e ao mesmo tempo demonstrar sua repercussão na realidade brasileira será o propósito desta dissertação.

Palavras chaves: Convenção de Basiléia, Brasil, comércio, resíduos industriais, transporte de resíduos. 


\begin{abstract}
The Basel Convention about movement control cross border of danger residues and your deposit it cames agree that definite organization mechanisms from movements cross border of solids residues and dangerous liquids and your last arrangement. The dangerous residues are material discarded that can place in risk the security of life. The Convention to reach its intention of existence allow to the previous and explicit concession of importation and exportation of the authorized residues between the countries that of it participate, in order to prevent the illicit traffic. Brazil through the Decree 1993 number 875 confirmed its permanence as integrant of the convention, thus inserting so the document in country. From now on, all the international trade of dangerous residues between Brazil and the exterior passed to be regulated. The industrial residues, considered dangerous constitute, in Brazil, ambient reason of concern of the authorities and agencies, either had to the amounts that come being generated, mainly as resulted of the raised industrial concentration in some regions of the country, either for the lack of installations and places adjusted for the treatment and destination. To describe and to argue the dimensions of this document and at the same time to demonstrate its repercussion in the Brazilian reality will be the intention of this communication.
\end{abstract}

Key words: Basel's Convention, Brazil, trade, hazard waste, transport. 
Introdução

A questão do desenvolvimento sustentável: de Estocolmo à Rio+10

1- Os tratados ambientais mundiais

2- A Ordem Ambiental Internacional

3- A Segurança Ambiental

Convenção de Basiléia

1- Panorama Histórico

1.1 - Diretrizes e Princípios do Cairo para o manejo ambientalmente saudável de resíduos perigosos

2- A Convenção

2.1 Estrutura Básica da Convenção

2.1.1-Conferência das Partes

3- Direito Internacional e Direito Internacional Ambiental e a Convenção

Ação governamental para a implantação da Convenção da Basiléia no Brasil

1- O Corpo Legislativo Brasileiro e a Convenção de Basiléia 
3- O Gerenciamento dos Resíduos Sólidos Industriais no Brasil

3.1- Os inventários estaduais de resíduos sólidos industriais no Brasil

4- Plano de desenvolvimento da convenção da Basiléia no Brasil

4.1- Plano Estratégico para a Implementação da Convenção da Basiléia no Brasil de 91 2005/2010

5 - Os Centros Nacionais de Tecnologias Limpas no Brasil

Capítulo IV - Aplicação da Convenção de Basiléia no Brasil

1- Materiais controlados pela Convenção no Brasil

1.1 - O Zinco

1.2 - O Cobre

2- Procedimentos para a importação da escoria de zinco e cobre no Brasil sob a égide da Convenção de Basiléia

2.1 - Leis

2.2 - Cadastro no Sistema de Comércio Exterior

2.3 - Taxa de Controle de Fiscalização Ambiental

2.4 - Laudo de análise

3 - Casos de aplicação da Convenção no Brasil

3.1- Brasóxidos Indústria Química Ltda

3.2- Ferreira Elias Representações Ltda

Considerações Finais

Referências Bibliográficas 


\section{Lista de Figuras}

Figura 1 - Incinerador da empresa Teris, São Paulo, Brasil.

\section{Lista de Tabelas}

Tabela 1 - Geração diária de lixo por habitante em alguns países

Tabela 2 - Produção de Resíduos em Alguns Países 45

Tabela 3 - Geração de Resíduos Sólidos Industriais no Brasil - Estados Selecionados 75

Tabela 4 - Geração de Resíduos Industriais no Estado de São Paulo 86

Tabela 5 - Geração de Resíduos Industriais na Bacia do Guanabara (RJ) 87

\section{Lista de Fotos}

Foto 1- Forno de Cimento que utiliza co-processamento da empresa Resotec em Cantagalo, Rio de Janeiro.

Foto 2 - Forno de Cimento que utiliza co-processamento da empresa Resotec em Pedro Leopoldo, Minas Gerais.

\section{Lista de Mapas}

Mapa 1 - Estados - Partes da Convenção 


\section{Anexos}

Decreto Número 875 de 19.07.1993 - Promulga o texto da Convenção sobre o Controle e Movimentos Transfronteiriços de Resíduos e Disposição Final

Decreto Número 4.581 de 27.01.2003 - Promulga a emenda ao anexo I e adoção dos anexos VII e IX à Convenção sobre o Controle e Movimentos Transfronteiriços de Resíduos e Disposição Final

Carta de importação de resíduos do Instituto Brasileiro do Meio Ambiente (IBAMA) sob a égide da Convenção de Basiléia 


\section{AGRADECIMENTOS}

Nesta etapa que se encerra da minha atividade acadêmica, eu não poderia deixar de agradecer às pessoas que estão sempre presentes ao meu redor. À minha mãe, por suas sábias palavras de luta e seus ideais, ao meu avô pelo grande afeto, carinho e palavras confortantes, e aos meus irmãos paternos e maternos que sempre me confortam com suas alegrias.

Também gostaria de agradecer ao Luís Henrique e, especialmente, ao meu companheiro Cláudio que sempre me deu auxílio em meus anseios profissionais. Não posso deixar de me lembrar das palavras de força de minha amiga Maria Ângela Comegna, desde o processo de seleção para o meu ingresso na pós-graduação da Universidade.

Não poderia deixar de agradecer à Universidade de São Paulo, especialmente a Pós-Graduação em Geografia Humana e a Pós-Graduação em Direito Ambiental. Gostaria de agradecer, da mesma forma, ao Instituto Brasileiro do Meio Ambiente e dos Recursos Natural Renováveis (IBAMA) representado por Zilda, Zélia e Lucy que contribuíram em muito para o avanço dessa reflexão.

E, acima de tudo, gostaria de agradecer a Deus por ter me possibilitado força para consolidar este trabalho.

Luciana Ziglio 
Os automóveis são um grande componente da economia industrial moderna, sendo, no entanto, apenas uma parte dela. Pense nos fluxos de material necessários à manutenção da produção industrial dos Estados Unidos, em termos biológicos, como se fosse seu fluxo metabólico. A indústria ingere: energia, metais, minerais, água, floresta, pesca e produtos agropecuários. Excreta resíduos líquidos e sólidos - diversos poluentes tóxicos degradáveis ou permanentes - e exala gases, que são uma forma de lixo. Os resíduos sólidos vão para os aterros, depósitos, ferro velho, reciclagem e para o mar. 0 lixo passa para a atmosfera, para os oceanos, rios, córregos, lençóis de água, solo, plantas, carne dos animais e das pessoas (especialmente para o aparelho circulatório humano). A maior parte desses fluxos industriais são invisíveis ou só parcialmente visíveis... No entanto, tomado em conjunto, diante do maior contribuinte do fluxo diário de material: o lixo na forma de refugo, de ganga, de cinza, de cimento, de fuligem, de escória, de gases de chaminé, de entulho, de metano, além de outros resíduos dos processos extrativo e fabril.

(Capitalismo Natural, Criando a Próxima Revolução Industrial, Fritjof Capra) 


\section{INTRODUÇÃO}

A Convenção de Movimentação Transfronteiriça de Resíduos Perigosos e Disposição Final

A movimentação transfronteiriça de resíduos ocorre desde longa data, no entanto, a partir da década de 1990 que ganhou espaço para reflexões com repercussões mundiais.

O Brasil acompanhou essas discussões, e sua efetiva inserção na temática foi com a assinatura da Convenção de Movimentação Transfronteiriça de Resíduos Perigosos e Disposição Final, comprovando que o País interessava-se em ações ecologicamente corretas.

O tema da pesquisa preocupa-se em analisar a Segurança Ambiental e os Resíduos Industriais, à luz da normativa, e a Convenção de Movimentação de Resíduos. Deste modo, analisaremos $A$ Convenção de Basiléia sobre o Controle de Movimentos Transfronteiriços de Resíduos Perigosos e Disposição Final apontando seus objetivos, limites, relações, fluxos e abrangências interrelacionadas, quando necessário, com a legislação ambiental brasileira. Gostaríamos de alertar aos leitores que usaremos ao longo do trabalho a multiplicidade das escalas para o tema, pois consideramos fundamental este mecanismo para a efetiva compreensão da existência da Convenção bem como de suas interações com o cenário de gestão de resíduos industriais brasileiro. Para tal meta, dividimos o trabalho nos capítulos exemplificados a seguir:

O Capítulo I, Segurança Ambiental, terá informações sobre o conceito de segurança ambiental e desenvolvimento sustentável divulgados internacionalmente a partir da década de 1990, fortalecendo a existência da Convenção e construindo a Ordem Ambiental Internacional.

O Capítulo II, Convenção de Basiléia, demonstrará o que significa este tratado para a Ordem Ambiental Internacional. Deste modo, mostraremos o panorama histórico de seu nascimento, seus principais objetivos e características para que o leitor entenda o motivo de sua existência. 
O Capítulo III , Ação governamental para a implantação da Convenção no Brasil, vem definir as atividades realizadas no País para aplicação da Convenção. A questão principal deste capítulo é demonstrar que se faz necessário pensar na gestão dos resíduos. Neste capítulo, também, serão citados os Centros Nacionais de Tecnologias Limpas no Brasil que funcionam como transmissores de tecnologias limpas para o setor empresarial.

O Capítulo IV, Aplicação da Convenção de Basiléia no Brasil, vem mostrar ao leitor os itens necessários no País para a realização da movimentação transfronteiriça por meio de dois casos de movimentação - a movimentação de resíduos de cobre e de resíduos de zinco.

Em Considerações Finais convidamos o leitor a perceber a importância da consciência ambiental e a mudança de paradigmas para o alcance do gerenciamento dos resíduos industriais. Sendo necessária a formação de políticas públicas que amparem a sociedade nesta problemática.

Em Anexos encontramos o texto da Convenção, o decreto que a promulga no Brasil e os laudos das empresas, deferidos pelo Instituto Brasileiro do Meio Ambiente e dos Recursos Naturais Renováveis (IBAMA). 


\section{CAPÍTULO I - A QUESTÃO DO DESENVOLVIMENTO SUSTENTÁVEL: DE ESTOCOLMO À RIO+10.}

Neste capítulo proporcionaremos um breve histórico das principais conferências ambientais mundiais, iniciando na Conferência de Estocolmo e concluindo com a Conferência Rio +10. As organizações desses eventos estruturaram o sistema internacional ambiental e construíram a ordem ambiental internacional ${ }^{1}$. Os documentos resultantes destes encontros permitiram a repercussão dos conceitos de desenvolvimento sustentável e de segurança ambiental que serão discutidos também neste capítulo. Assim, enunciou-se o desafio de garantir o equilíbrio da vida no Planeta Terra, divulgando mundialmente o conceito de desenvolvimento sustentável: crescer, explorar riquezas e produzir, sempre de forma a garantir que não se comprometa a condição natural e dos recursos, de modo a assegurar também o bem estar do ser humano. A implicação do conceito de desenvolvimento sustentável envolveu inúmeros aspectos aparentemente alheios à problemática ambiental, como exemplo temos: o comércio internacional e o exercício da reflexão da gestão dos resíduos industriais, sendo como fruto a idealização de que sem o estabelecimento de atitudes menos predatórias não será possível ter a continuidade de um padrão de vida com qualidade para a maioria da população.

O tema "Segurança Ambiental" é fundamental, porque se relaciona diretamente com a gestão dos resíduos industriais. Como sabemos, estes resíduos podem ocasionar alterações no equilíbrio da saúde humana e do meio ambiente, ferindo, portanto, os princípios de sustentabilidade e toda a continuidade histórica de conceitos discutidos nos grandes fóruns ambientais mundiais. A história da humanidade reúne inúmeros casos de impactos à saúde humana e ao meio ambiente, decorrente da utilização inadequada de insumos químicos, ou mesmo, quanto ao transporte de resíduos sem o mínimo de organização. Deste modo, faremos um breve histórico dos grandes marcos ambientais que se propuseram inserir a questão ambiental nos assuntos mundiais e, em seguida, apresentaremos o conceito de ordem ambiental, fruto desta manifestação mundial em preocupação com esse tema. Para finalizar, falaremos sobre a segurança ambiental, que é o tópico central deste trabalho, partindo da preocupação com a preservação da vida e do meio.

\footnotetext{
${ }^{1}$ Expressão utilizada por RIBEIRO, W. A ordem ambiental internacional. São Paulo: Contexto, 2001. pg. 93.
} 


\section{1- Os tratados ambientais mundiais}

Os problemas ambientais foram considerados de grande importância desde que foram difundidos ao mundo por ocasião da Conferência das Nações Unidas sobre o Meio Ambiente Humano, celebrada em Estocolmo, em 1972, com os temas: o desmatamento; a perda da diversidade genética dos recursos bióticos; a extinção de espécies; a erosão dos solos e a perda da fertilidade das terras; a desertificação; a contaminação química da atmosfera, dos solos e dos recursos hídricos; a produção e a disposição de resíduos tóxicos e lixo radiativo; a chuva ácida gerada pela industrialização e destruição da camada foliar das florestas; o aquecimento global e a rarefação da camada de ozônio, que ganharam definitivamente espaço para discussão, desde quando a comunidade internacional se reuniu para discutir o meio ambiente global e as necessidades de desenvolvimento com repercussões nunca antes vistas. A Conferência levou à criação do Programa das Nações Unidas para o Meio Ambiente (PNUMA) e a uma maior compreensão da necessidade de direcionar o modo como olhamos para o meio ambiente. Ela uniu, pela primeira vez, países industrializados e em desenvolvimento e, com isso, iniciaram uma série de Conferências da Organização das Nações Unidas que trataram de áreas específicas, como alimentação, moradia, população, direitos humanos e das mulheres.

Surge neste período a expressão Ecodesenvolvimento como informa Sachs:

O vínculo biunívoco e indissolúvel entre desenvolvimento e meio ambiente e o resultante conceito normativo de Ecodesenvolvimento, mais tarde rebatizado de desenvolvimento sustentável, foram discutidos na Conferência de Estocolmo em 1972. Essa discussão prosseguiu até resultar no Relatório de Brundtland. ${ }^{2}$

A lenta percepção de que o homem destruía o meio ambiente e passava a ameaçar a sua própria existência sofreu uma rápida aceleração nas últimas décadas, quando os estudos científicos passaram a informar à opinião pública o tamanho dos riscos, tais como: contaminação do ar, da água e do solo, problemas com saúde pública, desertificação, desaparecimento de espécies,

\footnotetext{
${ }^{2}$ SACHS, I. Estratégias de transição para o século XXI: desenvolvimento e meio ambiente. São Paulo: Nobel, 1993. pg.60.
} 
superaquecimento atmosférico, degelo e mudanças no nível dos mares e oceanos. E, como epílogo, fome, mortalidade crescente, ou seja, um cenário preocupante precedido por um relacionamento internacional a cada dia mais agressivo, devido à disputa cada vez maior pelos recursos naturais necessários à sobrevivência.

Mas porque o motivo desta reflexão repentina diante dos recursos naturais? Não nos iludamos que surgiu uma boa vontade internacional para inserir os temas nas agendas internacionais. Os seres humanos desde seu nascimento formam relações sociais e produzem frutos destas relações sociais. Desde quando nascemos produzimos resíduos frutos de nossa produção material decorrente do modo de vida adotado pela cultura que estamos inseridos. O homem usa esta natureza, constrói seu modo de vida, definido neste trabalho por cultura, e cria sua produção material. $O$ que não é mais interessante de sua produção material vira resíduo. Em um momento do tempo histórico foi detectado que a equação entre resíduos, produção e matéria - prima não admitia mais o sinal de igualdade. Somente assim vimos o despertar deste "desenvolvimento sustentável". Neste caso devemos lembrar da citação de Gonçalves:

A natureza se define, em nossa sociedade (ocidental), por aquilo que se opõe à cultura. A cultura é tomada como algo superior e que conseguiu controlar e dominar a natureza. ${ }^{3}$

Assim, enunciou-se o desafio de se garantir o equilíbrio da vida no Planeta Terra com o conceito do desenvolvimento sustentável: "crescer, explorar as riquezas e produzir", mas sempre de forma a garantir que não se comprometa a estabilidade das condições naturais e dos recursos, de modo a assegurar também o bem-estar das futuras gerações.

O anseio do desenvolvimento sustentável desenhou os contornos de uma revolução pacífica, movidos pela consciência do desastre iminente. Em 1982, uma avaliação dos dez anos pósEstocolmo aconteceu sob os auspícios do Programa das Nações Unidas para o Meio Ambiente (PNUMA) em Nairóbi, e desse encontro emergiu um chamado para a formação de uma Comissão Mundial de Meio Ambiente e Desenvolvimento, implementada em 1983. Em 1987, os resultados dessa Comissão apareceram como o Relatório Nosso Futuro Comum, também conhecido como Relatório Brundtland, devido à presidência da comissão da então primeira ministra da Noruega, Gro

\footnotetext{
${ }^{3}$ Gonçalves C. Os (des) caminhos do meio ambiente. Editora Contexto, São Paulo, 1.996, pg.23.
} 
Harlem Brundtland, tendo como uma de suas principais recomendações a realização de uma conferência mundial que direcionasse os assuntos ali levantados. Nesse documento foi usada pela primeira vez, a definição de desenvolvimento sustentável, caracterizada como o desenvolvimento que atende às necessidades das gerações atuais, sem comprometer a capacidade de as futuras gerações terem suas próprias necessidades atendidas.

Desse modo, no Relatório de Brundtland, o desenvolvimento sustentável em substituição ao Ecodesenvolvimento ficará definido como:

Desenvolvimento sustentável é aquele que atende às necessidades do presente, sem comprometer a possibilidade das gerações futuras de atenderem suas próprias necessidades. ${ }^{4}$

As implicações do conceito de desenvolvimento sustentável - a ecologia com desenvolvimento envolveram aspectos da vida social aparentemente alheios à problemática ambiental: relações e comércio internacionais, distribuição de renda, saúde, habitação, educação, cultura, políticas agrícolas, industrial científica e programas sociais em geral. Tudo isso foi uma decorrência lógica e natural daquele conceito básico de que o desenvolvimento sustentável só é possível com o conjunto da Humanidade estabelecendo com o nosso planeta relações menos predatórias que as estabelecidas pelo modelo de exploração da economia atual. Desse modo, além de mencionarmos a definição de desenvolvimento sustentável, segundo o Relatório de Brundtland, devemos relembrar as considerações de Barbieri:

Considerando que o conceito de desenvolvimento sustentável sugere um legado permanente de uma geração a outra, para que todas possam prover suas necessidades, a sustentabilidade, ou seja, a qualidade daquilo que é sustentável, passa a incorporar o significado de manutenção e conservação dos recursos naturais. Isso exige avanços tecnológicos que ampliem permanentemente a capacidade de utilizar, recuperar e conservar esses recursos bem como novos conceitos de necessidades humanas para aliviar as pressões da sociedade sobre eles. ${ }^{5}$

\footnotetext{
${ }^{4}$ Comissão Mundial Sobre Meio Ambiente E Desenvolvimento. Nosso Futuro Comum. Rio de Janeiro: Fundação Getúlio Vargas, 1991, pg.46.

${ }^{5}$ BARBIERI, J. C. Desenvolvimento e Meio Ambiente São Paulo: Vozes, 1997.pg.31.
} 
A Conferência Mundial sobre Meio Ambiente e Desenvolvimento, realizada no Rio de Janeiro em junho de 1992, a Rio 92, organizada pelas Nações Unidas e que trouxe ao Brasil mais de uma centena de chefes de Estado e de Governo, representou o coroamento desse sentimento de solidariedade universal, pelo qual se reconhecia a necessidade da mútua colaboração para equacionar as relações do homem com o meio ambiente. Mas, para atingir essa meta, tornava-se necessário definir uma série de compromissos. Cada país saiu da Conferência do Rio de Janeiro com a missão de definir suas obrigações, a partir de suas realidades, em busca do desenvolvimento sustentável. Tendo, cada país, obrigações regionais e locais, numa gradação de agendas que contemplassem tanto as realidades municipais, como os grandes desafios nacionais. Esse evento, na busca desta missão definida, gerou documentos do qual nos interessa particularmente a Agenda 21 em seu capítulo 19 - Manejo ecologicamente saudável das substâncias químicas tóxicas, incluindo a prevenção do tráfico internacional ilegal dos produtos tóxicos e perigosos; Capítulo 20 Manejo ambientalmente saudável dos resíduos perigosos, incluindo a prevenção do tráfico internacional ilícito de resíduos perigosos; Capítulo 37 - Mecanismos nacionais e cooperação internacional para fortalecimento institucional nos países em desenvolvimento inter-relacionados com a Convenção de Movimentação Transfronteiriça de Resíduos, definindo contornos interessantes e essenciais para a formulação de políticas públicas que visem ao alcance do desenvolvimento sustentável, atendendo às necessidades dos pobres, além de alertar para os limites do desenvolvimento quanto a ausência dos recursos naturais e os perigos da saúde humana perante a exposição de resíduos.

Tais capítulos integrantes da Agenda 21 relacionados com a gestão de resíduos perigosos, dentre eles os industriais, reafirmam a definição mencionada anteriormente de Barbieri, onde o cenário mundial pretende alcançar o desenvolvimento sustentável, nem que seja de forma parcial, pois sabemos que somente as assinaturas de tratados ou documentos ambientais internacionais não são suficientes. Sendo necessária a busca de avanços tecnológicos que permitam conservar ou reciclar recursos naturais como, por exemplo, equipamentos industriais que promovam uma produção menos destruidora ao meio ambiente e que não representem alterações de ordem tecnológica para a perpetuação do modelo de sociedade de consumo que vivemos. 
Após dez anos da realização da reunião Rio 92 e trinta anos depois da Conferência das Nações Unidas sobre Meio Ambiente Humano, ocorre a Rio +10 , Cúpula Mundial sobre Desenvolvimento Sustentável, para obter um plano que saísse do teórico e partisse para estratégias de ação formuladas até então. Desse modo, surgiu o Plano de Implementação (Plan of Implementation), fruto deste encontro.

A citação seguinte elucida as boas intenções discutidas nestes fóruns mundiais em busca de uma sociedade mundialmente sustentável, mas o que podemos claramente afirmar é que o caminho para a busca de uma sociedade mais justa economicamente, com qualidade de vida e acesso aos recursos naturais para todos está longe de ser alcançada. São necessários inúmeros encontros mundiais para divulgação da importância do desenvolvimento sustentável a todos e, acima de tudo, da importância de que os benefícios e lucros gerados na sociedade capitalista mundial sejam mais compartilhados. Vejamos:

Nós, os Chefes de Estado ou de Governos, reunidos na Conferência das Nações Unidas sobre Desenvolvimento Sustentável - Rio + 10 em Joanesburgo, África do Sul, de dois a quatro de setembro de 2002, reafirmamos o nosso compromisso de conquistar o desenvolvimento sustentável, da mesma forma que a Conferência das Nações Unidas sobre Meio Ambiente e Desenvolvimento o fez no Rio de Janeiro, dez anos atrás. Nós reunidos, em Joanesburgo, estamos convictos em que buscamos universalmente os direitos humanos e alcançar-lo-emos através de parcerias ou iniciativas diversas que possibilitem 0 acesso à água potável, saneamento, energia, saúde pública, segurança alimentar e proteção da biodiversidade. Ao mesmo tempo, promoveremos assistência financeira, abertura de mercados, desenvolvimento $\mathrm{e}$ transferência de moderna tecnologia, desenvolvimento de recursos humanos e treinamento desta mão-de-obra. ${ }^{6}$ (tradução da autora).

Especificamente sobre nosso tema de estudo, a gestão dos resíduos industriais foi discutido na Conferência Rio +10 , mas de forma ampla abordando não somente os resíduos industriais, mas

\footnotetext{
6 We, the representatives of the peoples of the world, assembled at the World Summit on Sustainable Development in Johannesburg, South Africa from 2-4 September 2002, reaffirm our commitment to sustainable development(...) We welcome the Johannesburg Summit focus on the indivisibility of human dignity and are resolved through decisions on targets, timetables and partnerships to speedily increase access to basic requirements such as clean water, sanitation, energy, health care, food security and the protection of bio-diversity. At the same time, we will work together to assist one another to have access to financial resources, benefit from the opening of markets, ensure capacity building, use modern technology to bring about development, and make sure that there is technology transfer, human resource development, education and training to banish forever underdevelopment. In: Draft Declaration submiteed by the President of the Summit, Johannesburg, 4 September, 2002, principles one and seventeen. Fonte: www.unep.org Acesso em 14.07.1992.
} 
também os resíduos perigosos. Desse modo, reafirmaram os princípios relacionados à gestão dos resíduos mencionados na Agenda 21, gerada na Conferência Rio 92, como a principal medida a ser tomada pelos países : a busca de padronização e de classificação de insumos químicos (matériaprima para a fabricação de alguns produtos). A previsão mínima para o alcance desse objetivo é em 2008 e a máxima em 2020. Assim teremos uma esperança em conseguir organizar os principais tipos de resíduos gerados em certos estabelecimentos, pois, claramente, saberemos quais os insumos que os produziram e, quiçá, a busca desta harmonização, também, acarretará uma melhor classificação dos resíduos. Vejamos agora alguns itens já citados no capítulo 20 da Agenda 21 que mencionam sobre os resíduos perigosos:

O controle efetivo da geração, do armazenamento, do tratamento, da reciclagem e da reutilização, do transporte, da recuperação e do depósito dos resíduos perigosos é de extrema importância para a saúde do homem e a proteção ao meio ambiente, o manejo dos recursos naturais e o desenvolvimento sustentável. Isto requer a cooperação e a participação ativas da comunidade internacional, dos Governos e da indústria. Para os fins desse documento, entendemos por indústria as grandes empresas industriais, inclusive as empresas transacionais e a indústria nacional. Prevenir ou reduzir ao mínimo a produção de resíduos perigosos, como parte de uma abordagem geral integrada de tecnologias limpas, depositar ou reduzir os movimentos transfronteiriços de resíduos perigosos (...) A ratificação da Convenção de Basiléia sobre 0 Controle dos Movimentos Transfronteiriços dos Resíduos Perigosos e Disposição Final e a rápida elaboração de protocolos correspondentes, tais como: o protocolo sobre responsabilidades e indenização, mecanismo e diretrizes necessários para facilitar a implementação da Convenção de Basiléia. ${ }^{7}$

Não nos iludamos diante das afirmações mencionadas anteriormente. Temos sim avanços significativos diante da organização dos grandes fóruns mundiais, bem como a organização de cartas ou tratados ambientais internacionais. No entanto, não são suficientes, sendo assim apenas 0 passo inicial. Devemos relembrar que não conseguiremos eliminar de nossa vida diária o uso de insumos químicos e impedir a geração de resíduos em indústrias. 0 modelo de sociedade ocidental preconiza a vida com consumo excessivo, utilizando recursos naturais e usando insumos químicos produzidos em unidades laboratoriais sem limites. Mesmo diante da assinatura de tratados e

\footnotetext{
${ }^{7}$ Agenda 21, capítulo 20, Introdução, item 20.1, pg. 1. Acesso em www.mma.gov.br/agenda21 em 28.11.2002.
} 
protocolos, como a Convenção de Basiléia, necessitaremos de mais atitudes no sentido de modificar realmente a realidade da organização de poderes econômicos e políticos entre os países ricos e pobres, pois, queiramos ou não, um processo decisório às divisas do Estado-Parte tem peso significativo diante de questões ambientais.

Pensando positivamente, a apologia realizada diante do conceito de desenvolvimento sustentável trouxe frutos. A comunidade ambientalista e as elites industriais, em sua maioria, começam a incorporar em seus discursos esse tema, mesmo que seja com os nomes de responsabilidade social e ambiental. Nesse sentido, devemos lembrar de Leff:

O discurso e as políticas de sustentabilidade estão abrindo um campo heterogêneo de perspectivas, marcado pelo conflito de interesses em torno da apropriação da natureza. Nos países do Norte, suas preocupações se concentram nos problemas ambientais globais que, rompendo os equilíbrios ecológicos do planeta, colocam em perigo a sustentabilidade do sistema econômico. ${ }^{8}$

Como citado acima, a busca da divulgação do conceito de sustentabilidade ou de um novo modelo de apropriação dos recursos naturais é simplesmente feita para a manutenção da reprodução econômica. Não nos iludamos, os problemas ambientais globais, como a chuva ácida, 0 aquecimento da superfície terrestre ou nosso próprio objeto de estudo, os rejeitos gerados pelos altos níveis de produção e consumo podem a médio e longo prazo impedir a perpetuação da qualidade de vida e o progresso das elites econômicas do sistema capitalista. Deste modo, por afetar esse atual padrão, a preservação do meio ambiente passa a ser considerada como um custo a ser internalizado pelo sistema econômico. Assim quando vemos em um discurso de sustentabilidade a passagem em que os países devem ter acesso a tecnologias limpas em sua produção industrial, notamos claramente a busca da integração do sistema econômico com as questões ambientais. Finalmente, o que o sistema econômico visa, na realidade, é a combinação entre os processos ecológicos e os processos econômicos puramente ditos, porque sem equacionar esses dois pontos, não é possível a perpetuação da vida capitalista ocidental.

${ }^{8}$ LEFF, H. Saber Ambiental: sustentabilidade, racionalidade, complexidade e poder. Rio de Janeiro: Vozes, 2001. pg.46. 
A expressão "Ecodesenvolvimento" para alguns autores e a expressão "Desenvolvimento Sustentável" ou ainda "Sustentabilidade nos Negócios" são certamente avanços consideráveis, mas não suficientes. É necessário aplicar na prática e não somente no discurso, ou seja, uma mudança de paradigmas e aplicação de fato das intenções formuladas nos encontros internacionais ambientais, para sim, efetivamente, buscarmos a segurança ambiental.

\section{2- A Ordem Ambiental Internacional}

A Terra é, no presente, o único Planeta do sistema solar que reúne as condições atmosféricas e biológicas para a vida humana. $O$ ser humano, com suas características atuais de perpetuação da vida, não se adapta a nenhum outro planeta conhecido. A Terra é ainda a moradia do homem, onde a utilização de técnicas de manejo florestal, o combate ao desperdício e a poluição são instrumentos que permitem a não-destruição dos sistemas naturais. O uso de técnicas de impacto ao meio ambiente, a intensificação da pobreza mundial, a percepção do uso utilitarista dos recursos naturais e, principalmente, a ameaça à perpetuação e manutenção da vida humana são os itens para 0 nascimento da ordem ambiental internacional e a busca da segurança ambiental. Mesmo com todo 0 avanço industrial, a reprodução da existência humana ainda mantém como sua base os recursos naturais, tais como: minérios em geral, vegetação e animais.

Deste modo, surge a ordem ambiental internacional, conforme afirma Ribeiro:

O conceito de ordem é empregado neste trabalho como medida de regulação da ação humana e como uma norma que estabelece limites para a intervenção. Por se tratar de uma ordem ambiental internacional, entende-se como aquela que é elaborada para restringir a ação humana no ambiente, seja ele natural ou não, em nível mundial. Do mesmo modo que se afirma uma ordem ambiental, é possível afirmar várias outras ordens internacionais. ${ }^{9}$

${ }^{9}$ RIBEIRO, W. A ordem ambiental internacional. São Paulo: Contexto, 2001. pg. 16. 
Os problemas ambientais perceptíveis ao homem, nas últimas décadas, não se limitam às divisões políticas dos países. 0 uso desenfreado dos recursos naturais e a visão mundial de que estes seriam infinitos, proporciona para a humanidade, como um todo, uma era de escassez. A tecnologia moderna permitiu a um número limitado de sociedades experimentar níveis de abundância sem precedentes, mas sempre utilizando insumos naturais para sua existência. A crise do meio ambiente destaca o fato de que estamos ficando sem recursos e, mais além, sem lugares para armazenar os resíduos gerados. Os avanços da industrialização e sua repercussão ampliaram o consumo desigual no mundo. Junto a esse fenômeno, verificamos que a população urbana dos países de baixa renda cresceu enormemente na última metade do século XX. No Brasil, o crescimento foi multiplicado por cinco nos últimos trinta e cinco anos. A proliferação das grandes cidades foi surpreendente nos países pobres. Das vinte e seis maiores cidades mundiais, em 1990, dezesseis estão em países de renda baixa ${ }^{10}$. Na maior parte dessas metrópoles, o destino final do lixo é inadequado.

Em diversas partes do mundo, encontramos exemplos de metrópoles que implantaram medidas efetivas para diminuir os problemas causados por uma sociedade que consume cada vez mais. Em 1989, quando o município de São Paulo iniciava seu programa de coleta seletiva, metrópoles como Paris, Tóquio e Nova York deram também início a programas de coleta diferenciada.

$\mathrm{Na}$ França, criou-se uma associação que congrega a capital e mais noventa cidades vizinhas. 0 volume de lixo na aglomeração parisiense ultrapassa pouco mais de um milhão de toneladas anualmente. Ele tem como destino a reciclagem e a incineração. Em Paris, os gestores elaboraram uma associação com noventa cidades para gerenciar os resíduos. Porém, não consegue reciclar mais que $22 \%$ do lixo gerado. 0 restante é incinerado ${ }^{11}$.

Em Nova York, que tem uma produção de lixo domiciliar de 1,5 quilo/dia por habitante, instalou-se a cobrança de uma taxa diferenciada para o gerenciamento do lixo. Adotou-se 0 transporte e 0 disposição final em outras áreas como soluções. Estima-se em cerca de quinze bilhões de dólares 0 gasto para transportar e acondicionar em municípios do entorno, que cobram para receber os

\footnotetext{
${ }^{10}$ Santos, M._Metamorfoses do espaço habitado. São Paulo: HUCITEC. 5 edição, 1997.

${ }^{11}$ Revista L Usine Nouvelle - Lês acteurs du recyclage parient sur une envolee.Avril de 1999.
} 
dejetos gerados pela população da metrópole. Em 2001 foi desativado o aterro sanitário que servia à Nova York. O programa de reciclagem absorve apenas $18 \%$ do total coletado ${ }^{12}$.

Em Tóquio, como em todo o Japão, não existem aterros. O lixo é colocado em barcos e levado para países vizinhos, que cobram pelo serviço. A reciclagem alcança o índice de $50 \%$ e o esforço de longo prazo para selecionar e reciclar o lixo faz com que cidades como Kamikatsu (na ilha Shikoku) realize a coleta seletiva em trinta e quatro categorias diferentes. ${ }^{13}$

O Brasil, como indica a tabela 1, apresenta média inferior de produção de resíduos sólidos urbanos quando comparado a vários países, sendo conseqüência, principalmente, das diferenças econômicas e sociais em seu extenso território. As áreas mais distantes e menos desenvolvidas compensam os altos volumes de centros urbanos como São Paulo e Rio de Janeiro que geram mais de $1 \mathrm{~kg}$ de resíduos sólidos por dia e por habitante.

Tabela 1 - Geração de lixo diária por habitante em alguns países

\begin{tabular}{|l|c|}
\hline País & Quantidade - quilo/habitante/dia \\
\hline Estados Unidos & 2,0 \\
\hline Japão & 1,9 \\
\hline Canadá & 1,7 \\
\hline França & 1,4 \\
\hline Países Baixos & 1,4 \\
\hline Alemanha & 0,9 \\
\hline Suécia & 0,9 \\
\hline Uruguai & 0,9 \\
\hline México & 0,8 \\
\hline Brasil & 0,7 \\
\hline
\end{tabular}

Fontes: Cempre/Tetra Pak Américas/Pro Europe/ Environmental Protection Agency (EPA) EUA.

IN: Cempre Informa número 75 maio/junho 2004 e Secretaria de Serviços e Obras da Prefeitura do Município de São Paulo, 2003.

A tabela 1 indica claramente que países de renda mais elevada geram mais resíduos. Os Estados Unidos, por exemplo, chega a gerar uma média por habitante diária equivalente a quase três vezes o que é gerado no Brasil. Países onde a reciclagem está mais organizada, como na Alemanha e na Suécia, tendem a um volume menor de geração de resíduos do que outros que também têm renda

\footnotetext{
${ }^{12}$ The New York Times - Nova York retoma programa de reciclagem do lixo. 25.07.2003.

${ }^{13}$ The New York Times - Como os japoneses despejam seu lixo. 27.05.2005.
} 
elevada. Entre países de renda média, destaca-se o Uruguai, que apresenta mais lixo diário que México e Brasil, países com economias mais dinâmicas que as do membro do Cone Sul.

Garantir a disposição e o tratamento dos resíduos urbanos em grandes cidades tornou-se um desafio nacional e mundial. A manutenção da falta de eficácia do sistema de gerenciamento revela uma insustentabilidade, sem precedentes, que pode levar a uma crise de oferta de recursos naturais, o quê torna impossível a continuação da relação atual da sociedade, cultura e consumo. ${ }^{14}$

Cabe notar que a questão ambiental não estava presente na análise estruturalista e no discurso da maioria dos economistas, independentemente da corrente de pensamento. A partir da década de 1970, essa questão ganhou espaço no debate econômico, ainda que marginalmente, ou seja, antes não havia preocupação com a sustentabilidade das atividades com pouca importância atribuída aos riscos de exaustão de recursos e a degradação do meio ambiente, deteriorando, assim, as condições de vida da população. Porém, o modelo de industrialização adotado mundialmente estava baseado e ainda mantém-se, desta forma, em recursos naturais e energia obtida, principalmente, pela queima de combustiveis fósseis. Essa base energética está associada a problemas de poluição ambiental. Mais agravante ainda é a industrialização periférica que adotou o modelo mencionado, que também passou a se caracterizar cada vez mais pela produção e exportação de commodities industrial de baixo valor agregado, mas com elevados níveis de poluição industrial. Deste modo, convém lembrar de Altvater quando ele menciona sobre a industrialização nos países do Norte e nos países do Sul:

O modelo de industrialização capitalista visivelmente não é universalizável; as exceções bem sucedidas desta regra não chegam a invalidá-lo. A sociedade capitalista afluente possui um lado ordeiro ao Norte, e um lado desordeiro ou caótico ao Sul. Não parece ser possível espalhar pelo mundo inteiro um modo de vida e de trabalho, que, em primeiro lugar, se baseia em um elevado consumo energético e material; e, em segundo, precisa dispor de sistemas energéticos e de transformação materiais eficientes e inteligentes; e que, em terceiro, precisa realizar e organizar nesta base uma prática de vida européia - ocidental, com os correspondentes modelos ideológicos e de pensamento e instituições políticas e sociais reguladoras. ${ }^{15}$

\footnotetext{
${ }^{14}$ Convidamos o leitor para a leitura do texto Urbanização, Modelo de Desenvolvimento e a Problemática dos Resíduos Sólidos Urbanos. RIBEIRO, H. e GUNTHER, W. In: Patrimônio Ambiental Brasileiro, Edusp, São Paulo, 2003. pg. 469-489.

${ }^{15}$ ALTVATER, E. O preço da riqueza. São Paulo, UNESP, 1995. pg.25. 333p.
} 
Necessitamos de mudanças de paradigmas, que envolvam economia, ecologia, política e história ao mesmo tempo e mais do que isso um esforço mundial no sentido da busca da proteção da estrutura terrestre independente da busca por poder militar e econômico. Mais do que nunca, a teoria do desenvolvimento sustentável é o ponto de partida para a preservação humana, designada como a possivel solução inicial para os impasses atuais. Precisamos implantar em larga escala a definição deste desenvolvimento no presente de forma urgente. Apenas para lembrar que consideramos que:

O desenvolvimento sustentável é aquele que atende às necessidades do presente sem comprometer a possibilidade de as gerações futuras atenderem as suas próprias necessidades contendo dois conceitos chaves - necessidades - sobretudo as necessidades essenciais dos pobres do mundo, que devem receber a máxima prioridade e - limites - que o estágio da tecnologia e da organização social impõe ao meio ambiente, impedindo-o de atender às necessidades presentes e futuras. ${ }^{16}$

A ordem ambiental consolida-se quando ocorre a adesão a um tratado de um país, assegurando sua posição no cenário internacional com relação a seu assunto. Como exemplo o caso do Brasil ao assinar a convenção de Basiléia, que permite o surgimento da primeira regulação da temática no território nacional e banindo a hipótese de tornar-se lixeira de resíduos industriais de outros países ou ainda em ser conivente com o comércio internacional e ilegal de resíduos. Apenas para ilustração temos a seguir alguns dados a respeito da movimentação transfronteiriça de resíduos da década de 1990. Observe:

Em 1989, quarenta milhões de toneladas, valor aproximado de US\$ 16 bilhões, foi destinado como sucata transfronteiriça entre os países da Organização para Cooperação e Desenvolvimento Econômico (OECD) ${ }^{17}$. De acordo com o Greenpeace, estima-se que 5.2 milhões de toneladas de resíduos perigosos foram exportados para o leste europeu e para os países em desenvolvimento entre 1986 e 1990 ilegalmente. O Greenpeace estima também que a exportação entre países membros e não membro da OECD entre 1989 e 1994 seja de 2.6 toneladas. 18

\footnotetext{
${ }^{16}$ Comissão Mundial Sobre Meio Ambiente E Desenvolvimento. Nosso Futuro Comum. Rio de Janeiro: Fundação Getúlio Vargas, 1991 pg.46.

${ }_{17}$ OECD, Waste Management Policy Group, Working Paper, number 3, for the 37 th meeting, march, 1993.

18 Greenpeace, 1990, Preface, and World Resources Report, 328p.
} 
Já mencionamos anteriormente a necessidade do sistema industrial capitalista em recursos naturais de forma desenfreada. Neste caso é indispensável que algumas nações sejam selecionadas como recipientes de resíduos não desejáveis em outras. Nesse caso, os países do Sul são escolhidos como os "depósitos" (locais de despejo onde os rejeitos gasosos, líquidos e sólidos possam ser absorvidos).

A ordem ambiental é uma vertente do sistema de relações internacionais que indica a frágil vontade política em avançar por grandes mudanças relacionadas com as questões ambientais. Assim, conforme Ribeiro, um país assina uma convenção, mas demora anos para ratificar, quando o faz, 0 que constitui é uma evidência de que os interesses nacionais precisam ser contemplados nas negociações:

O que efetivamente tem prevalecido são as vantagens econômicas e políticas que os paises podem auferir a cada rodada de negociações. E, o mais interessante: eles se comportam de maneira particular para cada tema destacado no arranjo institucional da ordem ambiental internacional. ${ }^{19}$

Para elucidar essa questão, podemos citar o caso do Brasil, que assinou a Convenção de Basiléia para evitar que o território nacional se transforme em lixeira de resíduos de outras nações ${ }^{20}$. Os tratados em sua maioria não são assinados com plena liberdade por todas as partes contratantes: eles traduzem uma relação de forças, consagram a vitória de uma parte e a derrota de outra, e caso um país se negue a assinar um tratado, ele poderá com este ato estar violando o direito internacional ambiental. Entretanto, como vivemos em um dinâmico processo de ajuste internacional envolvendo a temática ambiental, surgem novas oportunidades em que novos países podem alcançar posições de destaque no cenário internacional, mesmo que no aspecto econômico não tenham o domínio mundial. As palavras de Aron, em seguida, confirmam nosso pensamento:

\footnotetext{
${ }^{19}$ RIBEIRO, W.C A ordem ambiental internacional.Contexto.São Paulo, 2001.pg. 109.

20 É 0 caso de indústrias altamente poluidoras dos países centrais, que pressionadas por ações populares ou acossadas pela transposição dos seus equipamentos poluidores para os países periféricos, onde uma legislação mais "liberal" (inclusive quanto às normas de segurança) garante seu "pleno funcionamento", às vezes, com resultados catastróficos (basta lembrar casos como Cubatão no Brasil e Bhopal na Índia. In: WALDMAN, M. Ecologia e lutas sociais no Brasil. São Paulo: Contexto. 1992. pg.14.126p.
} 
A expressão do Direito Internacional concretiza-se nos tratados. Mas os tratados raramente são assinados com plena liberdade por todas as partes contratantes: eles traduzem uma relação de forças, consagram a vitória de uma parte e a derrota de outra ${ }^{21}$.... os tratados põem fim aos conflitos dos combates que provocam a ordem estabelecida anteriormente.$^{22}$ (grifos da autora)

Aqui encontramos como ferramenta para entendimento da Ordem Ambiental Internacional e a existência da Convenção de Basiléia. Morgenthau, principal responsável pela afirmação do realismo político entre as teorias de interpretação das relações internacionais, cita:

A soberania é a autoridade suprema de uma ação... que independe da autoridade de qualquer outra nação e igualmente de leis internacionais. Esse entendimento permite apontar que um dos objetivos do interesse nacional é justamente manter a soberania, apesar de o contrário ser amplamente divulgado em termos de ideologias globais. ${ }^{23}$

Tendo por base que o poder é a peça fundamental para a ação dos Estados com o propósito de salvaguardar sua soberania, o autor alemão contribui quando pensamos que para cada documento assinado entre países foram realizadas inúmeras reuniões até que se acomodassem as diferenças entre as Partes. Este modo de agir pensando em resguardar a soberania ou quando uma nação assina um tratado internacional simplesmente por satisfazer interesses próprios e não o pensamento de perpetuação da vida humana faz parte do cotidiano das políticas desenvolvidas pelas potências na defesa de seus interesses políticos, ideológicos, econômicos, ou estratégico-militares, buscando resguardar suas soberanias, neste caso, percebidas como invioláveis, reproduzida também no âmbito da questão ambiental. Na ordem ambiental, por meio da Convenção, a soberania está salvaguardada em sua estrutura bem como em seus anexos e emendas. Deste modo, o Brasil ao ter assinado a Convenção de Basiléia, buscou evitar que materiais de origem desconhecida fossem depositados em seu território, pois tem por objetivo a preservação de sua soberania enquanto País e, também, garantir a segurança ambiental de seus habitantes.

\footnotetext{
${ }^{21}$ ARON R. Paz e guerra entre as nações . Brasília: Universidade de Brasília, 1986. pg.169.

22 ARON R. Paz e guerra entre as nações. Brasília: Universidade de Brasília, 1986. pg. 254.

${ }^{23}$ MORGENTHAU, H. Politics among nations: the struggle for power and peace. New York: Alfred Knopf, 1973. In: RIBEIRO, W. A ordem ambiental internacional. São Paulo: Contexto, 2001. pg.19.
} 


\section{3- A Segurança Ambiental}

Suponhamos uma movimentação marítima em direção ao Brasil, advinda da Europa, de resíduos com substâncias que em interação com a água tornam-se inflamáveis espontaneamente ou emitem gases inflamáveis em quantidades perigosas cuja esta movimentação atravessará o Oceano Atlântico. No percurso desta carga não temos nenhum problema, mas ao chegar ao porto brasileiro ela tenha contato com a população do porto de forma indevida (manuseio ou abertura dos contêineres), ou ainda, o seu destino final para a gestão em território brasileiro não seja o mais adequado tecnologicamente o que possa acarretar uma exposição de toda a população a problemas de saúde em contato com este resíduo. Diante deste exemplo surgem algumas perguntas: o que fazer caso um movimento transfronteiriço acarretar um acidente, poluindo mares, oceanos, ar, fauna e flora? A quem responsabilizar pelo movimento transfronteiriço se o Estado não estiver possibilitado a receber tal resíduo? E caso ocorrer o recebimento, o Estado deverá expor sua população ao perigo? Alguns países têm acesso a tecnologias limpas, mas nem todos que recebem essa carga possuem este mecanismo, o quê fazer para não ocorrer acidentes?

Diferente do que ocorreu com o desenvolvimento sustentável, que foi elaborado ao longo de várias reuniões internacionais e serve como base para a implementação de políticas, a idéia de segurança ambiental global não está configurada como um conceito que leva à ação, mas sim à implementação de estratégias por uma unidade política diante da perspectiva limitada para o futuro quanto aos recursos naturais. Neste sentido, usamos as palavras de Eliott:

A expansão do discurso de segurança nacional, incluindo segurança ambiental, consiste em possibilitar espaço para a incorporação das questões ambientais, diante da necessidade de avançarmos com uma perspectiva crítica, limitada e problemática. (tradução da autora) ${ }^{24}$

A teoria da busca da segurança ambiental é fortalecida quando a Convenção de Basiléia em seu preâmbulo descreve a necessidade da gestão dos resíduos e a ameaça que estes podem causar à

\footnotetext{
${ }^{24}$ The expansion of the national security discourse to include economic security concerns provides some space for incorporating environmental concerns but, for those working within a critical perspective, it remains limited and problematic. In: ELLIOTT, L. The Global Politics and Environment. .Macmillan, 1998 pg.238.
} 
saúde humana e ao meio ambiente quando não bem administrados. Observe a seguir o preâmbulo da convenção reafirmando nosso pensamento:

Conscientes de que os resíduos perigosos e outros resíduos e seus movimentos transfronteiriços podem causar danos à saúde humana e à saúde do meio ambiente. (tradução da autora) ${ }^{25}$

Para evitar esta ameaça ao meio ambiente e aos seres humanos, os Estados estabelecem regras internacionais, como a Convenção de Basiléia, para impedir danos em escala mundial, tentando realizar, através da assinatura dos Estados Partes, a regulação e o controle do transporte de resíduos. Deste modo, o conceito de segurança ambiental é central para o entendimento da Convenção de Basiléia, pois reflete sobre a necessidade de manter as condições da reprodução da vida humana no Planeta conforme a sociedade de consumo.

A produção do lixo tem reforçado cada vez mais a noção de sociedade de risco ${ }^{26}$, devido ao fato de nos encontrarmos diante de resíduos com suas particularidades que não conhecem as fronteiras dos países para causarem ameaças à vida humana e à saúde do meio ambiente. A produção excessiva de dejetos pela sociedade moderna e pela indústria leva a limites não aceitáveis de lixo no planeta esperando por uma gestão. A sociedade está em risco cada vez mais, a partir do momento, que admite a produção industrial sem gestão de seus resíduos e que consome seus produtos, gerando mais resíduos novamente. Ou seja, em toda a cadeia de produção e consumo industrial e social, o lixo é produzido podendo causar ameaças diversas, colocando a população na insegurança da qualidade de vida e na sociedade de risco. Mais do que o transporte de resíduos entre os países, a preocupação maior é quanto aos resíduos transportados. Estes sim podem trazer os impactos que queremos alertar. Diante disto, a Convenção preocupa-se com o transporte, e acima de tudo, com 0 resíduo, pois este sim gera a insegurança e coloca a sociedade em risco. ${ }^{27}$

\footnotetext{
${ }^{25}$ Conscientes de que los desechos peligrosos y otros desechos y sus movimientos transfronterizos puedem causar daños a la salud y al medio ambiente. Preâmbulo da Convenção. Convém lembrar da afirmação de Martin onde menciona : Até o próprio homem, com toda sua enorme capacidade de adaptação se vê obrigado a deter-se diante de condições adversas, ainda que seja momentaneamente. In: Fronteiras e Nações, Martin. A Contexto, 1992. pg.16

${ }^{26}$ Segundo García Tornel: [...] Riesgo es una situación que implica peligro y que, ocasionalmente, puede tener desenlace catastrófico o no tenerlo (García-Tornel, 2001:11).

27 Convém mencionar que nem todos os resíduos industriais apresentam ameaça à saúde humana, mas para exemplificar, alguns resíduos que causam danos são: $0 \underline{\mathrm{HCB}}$ (hexaclorobenzeno) utilizado em sínteses orgânicas, sendo aplicado como fungicida para 0 tratamento de sementes e madeira contemplado na convenção como A4040 em seu anexo VIII; O PCB se refere à substância química bifenila policlorada, utilizada principalmente em transformadores elétricos chamada popularmente de ascarel e na convenção é contemplado como A3180 em seu anexo VIII.
} 
Os homens que usufruem o mundo do consumo capitalista, em sua plenitude e que vivem em seus países sem ameaças ao modo de vida que estabeleceram para si, não se preocupam quanto a ameaça à segurança, a escassez dos recursos naturais e a geração do lixo e de seu depósito, pois para esta elite da população mundial o pensamento é que a escassez não os afetará no momento, e sim apenas às futuras gerações. Ao atingir este ponto, a nossa preocupação será mais do que a ameaça à segurança ambiental, e sim a afirmação de que existe a prática da não-segurança ambiental.

Porém, à medida que as questões ambientais deixam de ser tratadas apenas nas esferas técnicas ou cientificas, passam a vincular-se a outras questões internacionais, tais como: as relações entre os países do Norte e do Sul; relações entre países industrializados; sistema de produção e exploração internacional dos recursos naturais, comércio internacional e a segurança dos Estados e indivíduos. Enquanto transita por estas relações, em muitas vezes, a segurança ambiental é colocada em segundo plano, pois neste momento a vantagem econômica é perseguida antes da proteção humana ou ambiental. Deste modo, podemos mencionar a citação de Garcia Tornel:

Abandonando o campo das relações entre a humanidade e seu meio, um novo capítulo de riscos aparece como conseqüência da atividade humana, a partir de estruturas criadas com a finalidade de favorecer o desenvolvimento econômico e social. ${ }^{28}$ (tradução da autora)

No entanto, este desenvolvimento econômico e social mencionado favorecerá milhares de pessoas no Planeta Terra, enquanto a ameaça ambiental e seus impactos afetarão a todos os seres humanos. Uma contaminação de qualquer resíduo mencionado na convenção não afetará somente os detentores do comando da gestão deste material, mas a todos que a ele estiverem expostos.

Deste modo, 0 conceito de segurança ambiental abriga três vertentes principais: 0 viés político, 0 viés econômico e o viés técnico. 0 viés político surge quando os países buscam a segurança para

${ }^{28}$ GARCÍA-TORNEL, Francisco Calvo. Sociedades y territorios en riesgo. Barcelona: Ediciones del Serbal, 2001. pg.95. 
garantir sua existência enquanto identidade de uma nação, quando os países se prontificam a assinar tratados que regulam a ordem ambiental, como por exemplo, a adesão dos países para que a Convenção de Basiléia entrasse em vigor. 0 viés econômico surge quando este se insere nas relações de comércio internacionais de resíduos, como por exemplo, uma sucata ser considerada matéria-prima em uma movimentação transfronteiriça entre estados. Por último, o viés técnico emerge quando definimos, por exemplo, o conceito de resíduos na escala nacional e buscamos com que este seja parte das políticas públicas nacionais que tratam do assunto. Deste modo, podemos relembrar Le Preste:

\footnotetext{
Os problemas ambientais se relacionam agora com a alta política internacional em virtude de seus enlaces potenciais com a distribuição do poder econômico e com as questões da segurança nacional. A noção de segurança ambiental é multiforme e seu caráter inovador, discutível. 0 conceito abrange um conjunto de fenômenos diversos, sendo uns clássicos, outros mais recentes ou que ganharam dimensões novas. A diversidade de concepções de segurança ambiental reflete duas preocupações distintas. Uns abordam esta noção de um ponto de vista essencialmente analítico. Outros se interessam em maior medida por seu caráter normativo e instrumental. 29
}

De acordo com o interesse de cada país diante do conceito de segurança ambiental, este é aproveitado em suas facetas conforme o benefício que representa e não diante da real necessidade de mudanças dos padrões de produção e consumo defronte ao impacto já presente na sociedade quanto aos efeitos da poluição. Quando as dimensões econômicas, políticas e técnicas da segurança ambiental não são equilibradas, podem ocasionar conflitos entre nações. Deste modo, a não segurança ambiental leva à possibilidade do nascimento de atrito entre nações a partir do momento que esta ferir a sua independência. Pensamos em uma movimentação transfronteiriça onde 0 governo de ambas as partes aceitam o trânsito, mas, no entanto, o estado importador ao receber a carga, depara-se com a impossibilidade de sua gestão. A devolução da carga para 0 estado exportador talvez não seja aceita. Esta situação poderá levar a um embaraço entre as nações que ocasionalmente venha a afetar as relações entre estes países. Os problemas ambientais envolvendo resíduos ainda não geraram ameaças de guerras entre as nações, mas esse tema já é previsto quando pensamos no exemplo citado anteriormente e vemos a citação de Elliot:

${ }^{29}$ LE PRESTRE, Philippe. Ecopolítica internacional. São Paulo: Senac, 2000. pg.475 
O estresse ambiental é identificado não como ameaça militar, mas as políticas ambientais assumem esta forma quando buscam a segurança ambiental ou a segurança econômica, suas relações podem gerar conflitos quando ameaçam a geopolítica de um Estado. (tradução da autora) $)^{30}$

É necessário priorizar a proteção ao meio ambiente sem esquecer o conceito de segurança ambiental também na escala do território dos Estados, pois os problemas relacionados à poluição são locais e mundiais, simultaneamente. O problema não é a degradação ambiental por si só e sim quando esta envolve violência e segurança. Quando uma população fica exposta a um perigo de impacto à saúde, pode-se justificar uma intervenção militar ao ameaçar a invadir o território de uma nação. Neste sentido convém lembrar de Elliott:

Nesta perspectiva, o interesse principal é (para) as mudanças ambientais que podem gerar e intensificar conflitos entre e dentro de estados. ${ }^{31}$

Para este trabalho, o conceito de segurança ambiental compactua com o nome "security environment" de Elliot Lorraine. Utilizaremos esta expressão quando pensarmos no impacto ambiental relacionado apenas a extensão territorial ou marítima, pois a convenção de Basiléia preocupa-se em regular a ordem de movimentação de resíduos entre Estados, priorizando os impactos que esta movimentação pode ocasionar na extensão territorial dos estados e nas águas nacionais e internacionais. A seguir a definição de Elliott:

A segunda definição enfatiza fixar a segurança e o ambiente, porque a integridade do ambiente é o objetivo da segurança, e a degradação ambiental deve ser considerada tão seriamente quanto ameaças militares tradicionais. ${ }^{32}$

\footnotetext{
${ }^{30}$ But even though environmental stress is identified as a non military threat, environmental politics are militarized because the human security or even economic security but by its relationship, through the potential for conflict, with the military and geopolitical security of the state. In: ELLIOTT, L. The Global Politics and Environment. Macmillan, 1998 pg.230.

${ }^{31}$ In this view, the major concern is the potential (for) major environmental changes to generate and intensify conflicts between and within states. In: The Global Politics and Environment, pg.220, 1998.
} 
A ameaça à segurança dos estados surge quando a ameaça ambiental emerge gerando uma possível intervenção militar a partir do momento que os recursos que existam sobre o poder de uma nação sejam prioritários para a perpetuação do modo de vida adotado pela civilização ocidental capitalista. Neste aspecto, em um futuro próximo, poderemos presenciar conflitos entre países que se neguem a receber ou queiram enviar cargas tóxicas de resíduos em seus territórios para tratamento ou disposição final. Talvez esta situação explique o motivo de países como os Estados Unidos, Zaire, Gabão e Angola não terem assinado a Convenção de Basiléia. De um lado, a necessidade de dispor lixo onde achar conveniente e, de outro, países que observam na gestão de resíduos novos mercados. Reafirmamos, então que não é necessário um estado de guerra para termos a degradação ambiental. Diariamente, no modelo de consumo e de estilo de vida capitalista adotado, temos este estado de degradação que levará certamente à escassez de recursos e ao acréscimo de resíduos. Deste modo, podemos afirmar que o meio ambiente é o recurso estratégico para os países.

Devemos mencionar o outro aspecto da segurança conhecido como "safety humankind" ou "segurança humana" (grifos nossos). É a expressão utilizada quando queremos pensar no impacto ambiental apenas relacionado com a proteção da saúde dos seres vivos. Segundo Elliot Lorraine o mesmo não é a causa direta dos conflitos militares entre as nações, mas pode ser um fator agravante em um processo de instabilidade. Observe abaixo trechos da autora ao abordar a questão da segurança humana:

Conseqüências sociais e econômicas, decorrentes da degradação ambiental e da escassez de recursos, especialmente a escassez de alimentos, podem também contribuir para legitimar e autorizar certas relações sociais. ${ }^{33}$

\footnotetext{
${ }^{32}$ The second approach emphasizes securing the environment by which the integrity of the environment is both security referent and security goal and in which environmental degradation is to be taken at least as seriously as traditional military threats. ${ }^{33}$ In: The Global Politics and Environment, pg.219, 1998.

${ }^{33}$ The social and economic consequences of environmental degradation and resource scarcity, especially food scarcity, may also contribute to a disruption in what Homer - Dixon calls "legitimized and authoritative social relations" In: The Global Politics and Environment, pg.227, 1998.
} 
Aqui, portanto, estamos preocupados apenas com a espécie humana e a questão dos estados ganha menor ênfase pelo menos por um momento. Neste sentido os acordos limitados às assinaturas dos Estados-Partes assumem o segundo plano onde o que nos importa é a preservação da saúde do homem. A crescente pobreza mundial e seu inverso o consumo excessivo por pequenas frações da população mundial leva à ameaça da segurança humana a partir do momento em que aceitamos todos os produtos advindos da indústria e desejamos consumi-los e produzimos dejetos. As indústrias por sua vez produzem resíduos e desejam realizar a gestão que poderá ser uma movimentação transfronteiriça. Então retornamos nosso pensamento na qual o que buscamos é a segurança da vida humana e as demais intenções são direcionadas para posições secundárias. Neste sentido é preciso buscar uma harmonia entre produção e dejetos para que possamos diminuir os possiveis impactos causados com a produção de resíduos e particularmente os industriais. $A$ assinatura de tratados como a convenção são tentativas positivas para o alcance deste equilibro. № entanto não nos iludamos de que simplesmente apenas esta atitude resolverá todos os problemas de segurança ambiental.

Por isto nosso capítulo dois, A Convenção de Basiléia, demonstrará o significado deste tratado, sua participação na ordem ambiental internacional e sua contribuição para o alcance da segurança. Deste modo faremos um panorama histórico de seu nascimento, seus principais objetivos, características para que o leitor entenda o motivo de sua existência. De certa forma a assinatura e 0 conhecimento deste documento pela sociedade desperta para a responsabilidade coletiva em permitir a continuidade da vida e fundamenta o papel do Estado em impor a lei e a ordem à sociedade. 


\section{Capítulo II - A Convenção de Basiléia}

O capítulo dois intitulado de A Convenção de Basiléia relatará o panorama histórico de surgimento deste tratado ambiental datado da Conferência do Cairo de 1987. Durante a década de 80, as leis ambientais dos países industrializados direcionavam para um crescente uso de internalizar os custos da disposição de resíduos perigosos. Diante disto era comum o comércio de resíduos perigosos de países industrializados para países em desenvolvimento e para a Europa Oriental. Quando esta atividade tomou fluxo e trafegando por inúmeros países sem nenhum controle e demonstrando ao mundo inúmeros casos que afetaram em diversas escalas a saúde humana e o meio ambiente surgiu a intenção da elaboração do tratado da Convenção de Basiléia. Nesta introdução queremos que o leitor entenda que a principal preocupação da Convenção é o de controlar a movimentação transfronteiriça de resíduos. Para isto conta com seu preâmbulo, vinte e nove artigos e seis anexos. Além disso, conta com as Conferências das Partes, o seu secretariado e os grupos técnicos de trabalho.

Em seguida para finalizarmos contaremos sua relação com o direito internacional, na demonstração para o leitor dos três princípios fundamentais para o Direito Ambiental sendo eles: o princípio da precaução, do poluidor pagador e da cooperação. O princípio da administração ambientalmente saudável, a busca da verticalização da convenção, por intermédio das leis nacionais e suas definições para discriminar as categorias de resíduos que compõem também o direito internacional serão abordados, pois a partir do momento que entrou em vigor atua na construção da Ordem Ambiental Internacional.

Devemos perceber que a Convenção é uma criação controlada, no presente, pelo Estado que participa deste acordo através da adesão ao tratado para evitar o descontrole, os desastres ambientais, a ameaça à saúde do homem ao estar em contato com resíduos industriais. 


\section{1- Panorama Histórico}

O fim da Guerra Fria acelerou a evolução do sistema internacional posto nos anos de 1980 a 1990. Tal evolução se caracteriza principalmente pela impossibilidade crescente de separar a política interna de um Estado da política externa, característica marcante da Ordem Ambiental. As grandes decisões econômicas advindas com o fim do bloco soviético, somados aos grandes encontros na área ambiental, geraram mudanças internas e externas nos países. Isto engendra uma nova dinâmica internacional, com a qual estão envolvidos numerosos personagens que formarão coalizões e opiniões mundiais. Os Estados, nesta nova Ordem, não são os únicos atores importantes. Organizações internacionais governamentais, empresas transacionais, organizações não-governamentais, desempenharão papéis decisivos.

A escalada armamentista deu um novo contorno à geografia do poder internacional. As duas superpotências desse mundo bipolar fizeram com que o espectro da morte rondasse a humanidade. As lutas de classes surgidas no interior da sociedade capitalista passaram a assumir uma conformação geográfica no chamado conflito Leste - Oeste. O desenvolvimento de tecnologias de destruição, como os mísseis nucleares de curto, médio e longo alcance, redirecionaram o papel das Forças Armadas que, até então, tinham a prerrogativa de defender a soberania das fronteiras do Estado Nacional. Possuir o domínio da tecnologia nuclear passou a ser condição para o exercício dessa soberania, razão que na década de 1950, por exemplo, houve a criação do Conselho Nacional de Pesquisas no Brasil, por inspiração militar.

Fazer política, nesse contexto era se mover num espaço de reduzidas alternativas, obrigando, quase sempre, a alinhamentos automáticos ou semi-automáticos a uma das superpotências. A posição geográfica da Europa, nesse contexto, afigurava-se como sui generis. De um lado, pôde efetuar sua reconstrução no pós-guerra, livre dos gastos militares, assumindo, então, os Estados Unidos o papel de guardião militar do autoproclamado "Mundo Livre". 
É do movimento pacifista, contra as ordens bipolares, que o movimento ambientalista retira suas energias. E é no movimento pacifista que emerge a posição ideológica que não aponta o capitalismo e nem o socialismo como um futuro promissor para a humanidade, posto que ambas as alternativas por estarem fundadas em tecnologias de destruição nuclearizadas, não seriam alternativas para a vida. No contexto da Guerra Fria, uma posição como esta não deixava de ser vista com desconfiança por qualquer um dos lados em confronto e, na melhor das hipóteses, era vista como ingênua. No entanto, o envolvimento cada vez maior das tropas norte-americanas no Vietnã, com as profundas baixas sofridas por suas tropas, fez com que o movimento pacifista ganhasse contornos de massa nos Estados Unidos e, também, galvanizasse enormes simpatias não somente nesse país, como na Europa. Não é de se estranhar que tenha sido exatamente na Alemanha, Estado que viu sua própria territorialidade redesenhada durante a Guerra Fria pelo muro de Berlim, que o movimento pacifista-ambientalista tenha se afirmado de modo mais significativo.

Este desdobramento do pacifismo para o ambientalismo deveu-se, sobretudo, ao fato de esse ter sido uma espécie de atrativo para uma série de transformações que vinham em processo de gestação, como as já indicadas, e que transcendiam o quadro político que se configurou com a Guerra Fria. Escapando de uma apropriação do tipo Capitalismo ou Socialismo, Leste ou Oeste, Estados Unidos ou União Soviética e burguesia ou proletariado, como costumavam ser o conflito naquele período, novos sujeitos sociais emergiram, entre eles o movimento ambientalista.

A critica à corrida armamentista e à afirmação do poder militar foi sendo, pouco a pouco, acrescida do caráter irracional dos investimentos militares, em meio a tanta miséria e de tanto desperdício, em virtude do consumismo desenfreado estimulado pelos meios de comunicação. Neste sentido, convém lembrar de Gonçalves:

A ecologia chegou a ser vista como uma espécie de ciência subversiva, sobretudo por sua denúncia de desperdício de recursos naturais em virtude do consumismo que, como vimos, era um dos sustentáculos do modelo Fordista - Keysnesiano - Sociedade Salarial. ${ }^{34}$

34 GONÇALVES, C. Geografia política e desenvolvimento sustentável. In: Revista Terra Livre, São Paulo, vl. 11-12 agosto de 1993. pg. $59-60$. 
Os desenvolvimentos ecológicos dos anos de 1980 a 1990 catalisaram uma reflexão nova sobre as relações entre a evolução ecológica do planeta e os problemas ambientais que os Estados enfrentam e, também, a uma aspiração política fundamental: a busca da segurança. No plano internacional, tornara-se claro que a sobrevivência da humanidade podia depender, ao mesmo tempo, do controle das armas nucleares e de uma gestão saudável dos fundamentos ecológicos da biosfera. Como afirmou George Kennan:

... nosso mundo enfrenta hoje, dois perigos supremos, sem precedentes. 0 primeiro não é somente o perigo de um conflito nuclear, mas o de uma guerra maior entre as grandes potências industriais, que a tecnologia moderna tornaria suicida para todos. O segundo perigo é posto pelo impacto devastador da industrialização e da superpopulação sobre o meio natural. Um ameaça destruir nossa civilização por meio de rivalidades militares temerárias e egoístas; o outro por meio de uma exploração abusiva e em grande escala do habitat natural dos seres humanos. Nossa experiência não nos preparou, em absoluto, para estes dois problemas, que são relativamente recentes. Os dois são urgentes. ${ }^{35}$ (tradução da autora)

O primeiro aspecto que nos chama a atenção, após o fim do bloco soviético, é a dimensão espacial em sua escala - Internacional, Sem Fronteiras, Mundo-World, Terra - de um lado e, de outro, da escala local, da comunidade, do espaço vivido dos cidadãos o que, por si só, indica que se inscrevem numa ordem que está para além (globalização) e aquém (lugarização/fragmentação) do Estado-Nação ${ }^{36}$. A Convenção de Movimentação Transfronteiriça de Resíduos Perigosos e Disposição Final surge no contexto histórico mencionado, exatamente no ano de 1989, a partir da Organização Internacional Governamental denominada Programa das Nações Unidas para o Meio Ambiente (PNUMA). Era um período de mudanças onde a questão ambiental começaria a ganhar espaços no cenário internacional, embora a convenção tenha surgido seguindo as regras ditadas no período que resumidamente era a regulação do comércio diante da organização do transporte dos resíduos perigosos. Mas, certamente, o seu plano de busca da não ameaça à segurança humana e ao meio ambiente também eram muito evidentes.

\footnotetext{
${ }^{35}$ KENNAN, G. Morality and foreign policy, Foreign Affairs, 64 (2), 1995 pg.218.

${ }^{36}$ Indicamos como leitura: HUNTINGTON S. The Clash of Civilizations and the Remaking of World Order. New York: Touchstone Book, 1997.
} 


\section{1 - Diretrizes e Princípios do Cairo para o manejo ambientalmente saudável de resíduos perigosos}

As Diretrizes do Cairo foram elaboradas com o propósito de orientar os Estados no gerenciamento dos resíduos perigosos. Nascendo em 1987, e sem validade jurídica, divulgam os principais conceitos que fundamentarão mais tarde a Convenção de Basiléia, tais como: a transferência de tecnologia e uso de tecnologias limpas; minimização da geração de resíduos; notificação e o consentimento prévio para o transporte de resíduos. As diretrizes servem, portanto, como base para a formulação do plano de discussão dos tópicos que constituirão a Convenção de Basiléia, ou seja, formando assim seu estágio embrionário.

O grupo de trabalho formado para a construção desta diretriz reuniu-se em Budapeste em 1987 e tinha para a o início de seus trabalhos as informações organizadas pela Organização para Cooperação e Desenvolvimento Econômico (OCDE) em 1974 que na ocasião, em seu Comitê de Meio Ambiente, criou-se a equipe política de manejo de resíduos. Desde 1974 existia na OCDE o grupo de trabalho Waste Management Policy Group com o propósito de fornecer subsídios jurídicos e técnicos para o gerenciamento de resíduos. Foi na OCDE, que surge pela primeira vez o conceito de poluição, contribuindo fundamentalmente para o nascimento da Convenção bem como da preocupação com este tema. Tal grupo do Cairo deveria elaborar o texto da convenção levando em consideração:

Definição minuciosa dos resíduos sólidos perigosos;

Selecionar os principais aspectos dos documentos internacionais de importação e exportação dos resíduos perigosos;

Definição minuciosa do conceito de consentimento prévio;

Alternativas para assistência aos países no sentido de capacitação para monitoramento e eliminação de resíduos perigosos.

Diante destes princípios, o grupo de trabalho também deveria atentar-se para as discussões que surgiam de diversos atores da ordem internacional como as Organizações Não-Governamentais (Ongs), Nações e o setor privado. Com relação aos estados dos países do Norte industrializado e os 
do Sul em desenvolvimento, que mais uma vez estabeleciam, assim como no plano econômico, a bipolaridade Norte-Sul. Os países industrializados concebiam os resíduos como futuras matériasprimas, portanto, possíveis de serem transportados sem ilegalidade e comercializáveis. Decorrentes deste pensamento podemos citar que:

Os resíduos destinados a disposição final são resíduos e, como tais, devem ser regulados. No entanto, os insumos que os membros do Bureau of International Recyclingn (BIR) transportam para a indústria manufatureira, em todo o mundo, não são resíduos como tampouco nunca 0 serão. Esses produtos estão prontos para uso como matéria-prima secundária. ${ }^{37}$

Deste modo, podemos perceber que a conjectura para o estabelecimento dos passos iniciais da estrutura da Convenção de Basiléia era tumultuada, pois de um lado existiam os países que se beneficiavam com o comércio livre de resíduos e, de outro, nações que serviam como apenas gestores destes resíduos mencionados como materiais secundários. A existência de normas poderia vir a dificultar esta movimentação. 0 exemplo abaixo consolida mais uma vez nossa explicação:

\footnotetext{
Entre os países industrializados, excetuando-se a Dinamarca, Suécia e Países Baixos, havia um consenso quanto a isto, a inclusão na Convenção da proibição total da exportação (de resíduos perigosos) não haveria de entrar em debate. Os opositores, tais incisivos da proibição, sendo ao mesmo tempo, os países que assumiram a condução das negociações, que eram aqueles que despacham as maiores quantidades para os países em desenvolvimento... Desses, os Estados Unidos e a Grã-Bretanha representam as posições mais radicais, pois eles desejavam que o comércio de resíduos transcorresse como comércio de mercadorias, livre de restrições. ${ }^{38}$
}

Deste modo, temos de um lado os países interessados no não nascimento da Convenção de Basiléia, mas de outro lado, temos organizações não-governamentais (Greenpeace) ou países favoráveis a elaboração das diretrizes do Cairo, base para a Convenção. Qual seria a alternativa mais sensata diante deste impasse? Ora tal questão já está respondida a partir do momento que, em 1989, surgiu através das adesões necessárias à aceitação internacional da Convenção de Basiléia

\footnotetext{
${ }^{37}$ BIR - Bureau of International Recycling, 1999. pg.9. Tradução de Ferreira ,G - Natureza jurídica e definição de resíduos perigosos na Convenção de Basiléia. São Paulo. USP.2003.

${ }^{38}$ SCHAPER, H. Die theorie kommunikativen handelns - eine flaschenpost. Heft , 1995. pg. 36) Tradução de Ferreira ,G - Natureza jurídica e definição de resíduos perigosos na convenção de Basiléia. São Paulo. USP.2003.
} 
e, neste contexto, o Brasil aderindo ao tratado, em 1993, posicionando-se como país em desenvolvimento que aceita a regulação do comércio internacional de resíduos entre países.

Mas, diante deste conflito de interesses e nações com poderes de decisões efetivamente influentes, como acreditar que houve por estas a aceitação da elaboração das Diretrizes do Cairo e da Convenção de Basiléia? Diante de inúmeras respostas podemos afirmar que o grupo técnico reunido para consolidação desta tarefa chegou ao consenso de que os Estados-Partes, na década de 1990, não possuíam domínio técnico para a gestão dos resíduos em todos os seus territórios. Neste sentido, não há segurança ambiental, na possível movimentação de resíduos. Tal argumento foi decisivo para o nascimento deste documento, pois, como sabemos, até hoje as tecnologias existentes não conseguem (após dezoito anos após a consolidação das diretrizes do Cairo) fazer a gestão de todos os resíduos de nossa sociedade. Para finalizar, segue a citação abaixo reafirmando a insuficiência tecnológica pertinente ao tema presente até hoje. Observe:

\footnotetext{
As diretrizes reconheceram, aos países em desenvolvimento, a necessidade de assistência técnica do mundo industrializado para assegurar o manejo ambientalmente saudável de resíduos perigosos, e apontaram para a necessidade de que se tenha acesso a toda informação relativa a essa atividade e requerem que as legislações nacionais dispontam sobre a responsabilidade e compensação por danos em caso de acidente ou de negligência, imprudência ou imperícia no manejo dos resíduos. ${ }^{39}$
}

Sejamos sinceros para o encerramento do histórico da elaboração das diretrizes para a Convenção, Para que a preocupação com detritos diante de uma sociedade que visa ao uso desenfreado de recursos naturais? Ora, possuímos uma sociedade baseada no consumo e que se preocupa com 0 recurso natural quando este é transformado em produto que servirá para manter seu modo de vida. A partir do moment o em que este recurso, transformado em produto, foi consumido e por fim perder o valor para a sociedade este será descartado e, portanto não mais detentor de valor agregado. Não é pertinente a preocupação com o que não tem valor em uma sociedade baseada no valor.

${ }^{39}$ Cambridge, 1998. pg. 28. Tradução de Ferreira,G. Natureza jurídica e definição de resíduos perigosos na convenção de Basiléia. São Paulo. USP. 2003. 


\section{2- A Convenção}

Até 1980, as movimentações de resíduos perigosos e os impactos ambientais que os resíduos puderam promover, não faziam parte de questionamentos pelos Estados, embora a preocupação com a temática já tenha surgido na Declaração das Nações Unidas sobre o Meio Ambiente Humano, em 1972. Como exemplo desta afirmação, podemos relembrar em linha cronológica apenas alguns grandes casos de movimentação de resíduos que proporcionaram problemas:

O primeiro exemplo ficou conhecido como o Caso Minamata, ocorrido no Japão, em 1950, onde os habitantes consumiram peixes contaminados de resíduos de mercúrio provenientes da empresa Chisso. Era o primeiro sinal de um dos exemplos mais dramáticos envolvendo a poluição industrial na história do homem. Contudo para aqueles de nós, agora, que podem ver mais distante, este episódio oferece também um exemplo poderoso da concentração dos elementos químicos em alimentos, afetando os seres humanos e o seu ambiente. Minamata está situada na costa ocidental de Kyushu, no Japão. Sua história começa nos anos de 1930, com a cidade voltada para a pesca e cultivo na vila. Em 1932, o Chisso Corporation, parte integral da economia local desde 1907, começou a manufaturar o acetaldeido, usado para produzir plásticos. Como nós sabemos agora, o mercúrio do processo de produção começou a derramar na baía. Embora, com desconhecimento de todos, mais tarde, o metal pesado mercúrio na forma de cloreto de mercúrio é um elemento orgânico que poderia entrar na corrente sanguínea através da ingestão de alimentos. Então, os residentes de Minamata com base alimentar quase exclusivamente em peixes e em mariscos da baía foram contaminados. Para nós, hoje, a ameaça da poluição é imediatamente evidente. Mas, no contexto histórico em questão foi uma surpresa esse impacto. A baía era utilizada como fonte de alimentação para muitos moradores, bem como geração de renda para a comunidade. A população sofreu com mortes e, também, com as conseqüências diante da exposição a resíduos químicos. Veja a citação abaixo demonstrando a revolta da população local na época do acidente:

40 Trecho da carta de protesto em frente à sede da Chisso em Tóquio. In: MOKHIBER, R. O Caso Minamata. s.n.s.d. 4p. 
Mas, a seqüência de relatos ainda está no início. Temos o caso do cargueiro Khian Sea que navegou por quase dois anos a procura de um local para depósito das cinzas provenientes de incineração da Filadélfia tendo como desembarque as ilhas do Haiti e, também, os conhecidos cargueiros de Jelly_Wax e Ecomar que, em 1987, enviaram o equivalente a quatro mil toneladas de resíduos contaminados da Itália para a Nigéria. ${ }^{41}$

Devemos relembrar também o caso de Bhopal ocorrido em 1984 quando tal cidade sofreu com os insumos químicos da empresa Union Cambridge. Em Bhopal, na noite do dia dois para o dia três de dezembro de 1984, quarenta toneladas de gases letais vazaram de uma fábrica de pesticidas da Union Cambridge, hoje pertencente a Dow Química. No desastre, vinte mil pessoas foram mortas. Além disso, ao menos cento e cinqüenta mil sofrem até hoje de doenças crônicas resultantes do vazamento. Os sobreviventes e suas crianças ainda sofrem de problemas de saúde como câncer ou tuberculose, ou defeitos de nascimento. Veja o relato da imprensa local demonstrando a gravidade do evento:

\begin{abstract}
Estava tentando sintonizar uma das estações estrangeiras de rádio, por volta de 2:30 p.m., quando senti uma certa asfixia na garganta. Tive a sensação de queimadura nos olhos. Abri a porta do quarto, não sei por quê. Primeiro, achei que era um problema no hotel. Saí. Estava procurando um espaço aberto onde pudesse buscar alívio, mas não encontrei alívio em lugar algum. Quando saí do hotel vi bandos de pessoas se movimentando na mesma direção. Foi uma experiência horrível. Vi senhoras quase sem roupa, saídas da cama, crianças agarrando-se aos seus colos, todas se lamentando, chorando, algumas vomitando, algumas vomitando sangue, algumas caindo, presumo agora que morrendo... O céu estava claro e enquanto eu andava, podia ver as estrelas. Não senti cheiro algum, talvez por causa do pânico, mas as pessoas estavam dizendo que 0 ar cheirava a amêndoas podres. ${ }^{42}$
\end{abstract}

No dia seguinte do relato mencionado anteriormente foram hospitalizados, em Bhopal, cerca de vinte mil pessoas decorrentes da exposição ao isocianato de metila, produtos químicos utilizados nas instalações da Union Cambridge para a produção de pesticidas. Tal unidade estava desativada por volta de dois meses, mas em dezembro fora escolhida para sofrer manutenções de limpeza, onde os

${ }^{41}$ FERREIRA, G. Natureza Jurídica e Definição dos Resíduos Perigosos. São Paulo: Tese de Mestrado. Universidade de São Paulo. 2003. 182p.

42 Relato do jornalista Aness Christi.In:MOKHIBER, R. O Caso Bhopal. S.n. S.d. $5 p$. 
trabalhadores nesta atividade notaram o vazamento de tanques que proporcionou a liberação do produto em contato com a água liberada na limpeza de rotina. Neste incidente, presenciamos 0 número de cinco mil óbitos, duzentos mil ferimentos leves e quarenta mil ferimentos graves.

Ou ainda, recentemente envolvendo o Brasil, mesmo diante de toda a movimentação nacional a respeito do tema. Em abril de 2005, o navio MV Sonia, contendo um carregamento de melaço contaminado com o hormônio de crescimento MPA (acetato de medraxyprogesterona) retornou para Amsterdã, na Holanda, seu porto de origem. Os responsáveis pelo navio foram informados pelas autoridades brasileiras de que não seriam autorizados a descarregar no país, como estava previsto anteriormente.

A fonte desse resíduo era de uma empresa holandesa, chamada Schuurmans en Van Ginneken (SvG), uma das maiores fornecedoras mundiais desse elemento. 0 carregamento, tóxico foi vendido para a destilaria Gramane Industrial e Agrícola S.A. (GIASA), localizada em Pedro de Fogo, na Paraíba. Os resíduos que seriam vendidos também são classificados como perigosos pelas autoridades da União Européia (UE).

O MPA (acetato de medraxyprogesterona) é um hormônio de crescimento artificial que altera 0 funcionamento do sistema endocrinológico, apresentando efeitos colaterais tóxicos. Especialistas acreditam que o MPA pode causar infertilidade em seres humanos. 0 governo holandês, em carta ao governo brasileiro, confirmou a contaminação do carregamento. O Instituto Brasileiro do Meio Ambiente e dos Recursos Naturais Renováveis (IBAMA), também em reação ao documento enviado pelo governo holandês, informou que o material tóxico seria impedido de descarregar no País e que deveria retornar ao país de origem. Como medidas para proibir o descarregamento informou que foram acionados os escritórios regionais responsáveis pelos prováveis portos de atracamento. ${ }^{43}$

\footnotetext{
43 O Greenpeace sabia que o carregamento havia sido aprovado pelo Ministério do Meio Ambiente, por notificação IBAMA $n$. 94/Diliq/CGQUA/2003, ref. processo 02001.000939/2003-41, datado de 19 de fevereiro de 2003. Essa autorização foi dada desde que as concentrações do hormônio não ultrapassassem 30 ppb (partes por bilhão) de MPA. Entretanto, algumas amostras indicavam até $223 \mathrm{ppb}$ de MPA. Não temos explicações do motivo pelo qual o governo holandês autorizou esse carregamento para o Brasil contendo até $30 \mathrm{ppb}$ de MPA no melaço. Esse carregamento é uma violação da lei européia que proíbe a exportação de lixo tóxico para países em desenvolvimento. $O$ caso mostra que essa proibição por parte do governo holandês e da União Européia falhou, pois o carregamento foi autorizado e estava a caminho do Brasil. O Brasil é signatário da Convenção da Basiléia desde 1992.
} 
Poderíamos enumerar neste trabalho vários casos de desastres envolvendo meio ambiente, saúde humana e resíduos perigosos conhecidos mundialmente. O caso Bhopal, Minamata e os demais citados anteriormente evidenciam a ausência de gerenciamento e de punições legais para 0 transporte e disposição de resíduos perigosos.

Deste modo, os responsáveis pelo gerenciamento de resíduos perigosos, diante do acúmulo de desastres, lançaram-se em busca de alternativas para os mesmos, devido às limitações impostas nos Estados gerados.

Durante a década de 1980, as leis ambientais dos países industrializados direcionavam para um crescente internalização dos custos da disposição de resíduos perigosos. Diante disto era comum 0 comércio tóxico de lixo de países industrializados para países em desenvolvimento e para a Europa Oriental. Quando esta atividade tomou fluxo e trafegando por inúmeros países sem nenhum controle, surgiu a adoção da Convenção de Basiléia. Torna-se o primeiro tratado sobre o assunto, com vinte e nove artigos e seis anexos fazendo correlação com a Convenção de Montego Bay, Convenção do Consentimento Prévio e Convenção de Poluentes Orgânicos Persistentes e Convenção por Dumping. Nosso objeto de estudo está preocupado em seus anexos e artigos, ao regular a movimentação transfronteiriça, visando reduzir e assistir os movimentos transfronteiriços de resíduos, desejando com este princípio garantir as seguranças ambientais, humanas e a regulação comercial dos resíduos. Prioriza a redução da geração de resíduos e, em seguida, aprova a movimentação transfronteiriça para que seja realizado o adequado gerenciamento do resíduo ou este seja endereçado a produção limpa evitando, portanto, o trânsito de materiais.

Em 1989 surge seu texto depois da aclamação pública contra a indiscriminada transferência de resíduos entre países. Uma conferência diplomática aconteceu em Basel (Suíça) adotando a Convenção. No entanto, apenas em 1992 entra em vigor. Em 1995 surge a classificação e caracterização dos resíduos através do grupo técnico de trabalho da Convenção, que concorda em listar resíduos como perigosos ou não. Estas listas serão mais tarde adotadas pelas partes e, desse modo, ratificaria o seu escopo formando seus anexos. Na década de 1989 a 1999, a Convenção estava direcionada a estabelecer uma estrutura de controle de movimentação transfronteiriça de resíduos perigosos, que seria o movimento de resíduos através de fronteiras entre países e, 
também, com o seu fortalecimento enquanto tratado ambiental mundial. Observe a seguir a tabela 2 que demonstra a geração de resíduos de alguns países neste período de 1995, ano em que foi organizada a listagem de resíduos considerados perigosos da Convenção.

\begin{tabular}{|l|c|c|c|c|c|c|}
\hline \multicolumn{7}{|l|}{ Tabela 2 - Produção de Resíduos em Alguns Países } \\
\multicolumn{1}{|c|}{ País } & Total & Construção & Energia & Indústria & Outros & $\begin{array}{c}\text { Lixo } \\
\text { Municipal }\end{array}$ \\
\hline Áustria & 25.770 & 6.400 & 775 & 14.284 & 201 & 4.110 \\
\hline Bélgica & 28.864 & 7.718 & 1.135 & 13.359 & 1.256 & 5.007 \\
\hline Dinamarca & 11.609 & 3.427 & 1.775 & 2.736 & 845 & 2.26 \\
& & & & & & \\
\hline Finlândia & 43.800 & 8.000 & 3.000 & 15.400 & 300 & 2.100 \\
\hline França & 235.600 & 24.000 & & 101.000 & & 35.600 \\
\hline Alemanha & 338.602 & 131.645 & 25.310 & 65.119 & & 48.715 \\
\hline Grécia & 20.805 & 3.400 & 7.000 & 2.905 & & 3.600 \\
\hline Irlanda & 10.476 & 1.520 & 353 & 3.781 & 774 & 1.848 \\
\hline Itália & 106.129 & 14.311 & 1.330 & 22.208 & 42.500 & 25.780 \\
\hline Portugal & 8.066 & 3.200 & 392 & 418 & 84 & 3.500 \\
\hline Espanha & 99.209 & 115 & & 13.800 & 380 & 14.914 \\
\hline Suécia & 66.290 & 1.500 & 600 & 13.990 & & 3.200 \\
\hline Reino Unido & 265.000 & 70.000 & 13.000 & 560.00 & 15.000 & 29.000 \\
\hline Noruega & 17.188 & 3.578 & & 3.288 & & 2.722 \\
\hline
\end{tabular}

Podemos perceber, na tabela 2, que a geração de resíduos industriais é alta e poderíamos somar a estes valores também uma certa porcentagem dos resíduos de construção. Tais países, em sua maioria, têm acesso aos mais avançados sistemas de gerenciamento ambiental de resíduos evitando, portanto, a necessidade de movimentação de lixo. A questão de proteção ambiental e humana, referenciando os resíduos, são destacadas a partir da Convenção. Anterior a Basiléia qualquer movimentação de resíduos não infringia nenhuma lei, pois não existiam restrições ${ }^{44}$.

\footnotetext{
${ }^{44}$ A Convenção de Roterdã sobre o Procedimento de Consentimento Fundamentado Prévio Aplicável a Certos Pesticidas e Produtos Químicos, instituída a partir de onze de setembro de 1998 é fruto das atividades de consentimento prévio surgidas com London Guidelines, buscando a segurança química quanto às substâncias por ela contempladas. 0 procedimento conhecido como procedimento de prévia informação e consentimento (PIC) foi aditado em 1989 para ajudar a controlar as importações de produtos químicos indesejados que tinham sido proibidos ou severamente restringidos.Os Poluentes Orgânicos Persistentes (POPs), objeto da Convenção de Estocolmo, representam uma classe de poluentes químicos, que podem trazer sérias ameaças aos seres vivos e ao
} 
A Convenção, como já mencionamos, é adotada diante da consolidação das diretrizes do Cairo, em 1987, e da aclamação pública em Basel no ano de 1989. Em 1992 entra em vigor tornando-se um documento internacionalmente reconhecido e, portanto, efetivamente controlando 0 trânsito de resíduos perigosos. A sua natureza jurídica é multilateral, ou seja, para que haja a movimentação transfronteiriça de resíduos, ambos os estados devem permitir o consentimento, e o Brasil ,no mesmo de sua validade jurídica, adere ao tratado na esfera federal.

O Brasil ratifica a sua participação na Convenção em 1993 através do decreto 875, de 19/07/93, em anexo neste trabalho. $O$ objetivo mestre da Convenção é o de estabelecer obrigações com vistas a reduzir os movimentos transfronteiriços de resíduos perigosos ao mínimo, com manejo eficiente e ambientalmente seguro, minimizar a quantidade e toxicidade dos resíduos gerados, preparar seu tratamento (depósito e recuperação) ambientalmente seguro e próximo da fonte geradora e assistir aos países em desenvolvimento na implementação destas disposições.

Para atingir seu objetivo principal, as partes devem assegurar que a geração de resíduos seja reduzida a um mínimo, e que o gerador destes resíduos cumpra suas tarefas quanto ao transporte e disposição final de forma a proteger a saúde humana e o meio ambiente, devendo tomar consideração para que os mesmos sejam depositados no Estado pelo qual foram gerados, assegurando instalações ambientalmente adequadas para a disposição final. Os Estados devem impedir a importação de resíduos perigosos se tiverem razões para crer que os mesmos não serão administrados de forma ambientalmente saudável (como, por exemplo, exigir que estes resíduos sejam embalados, etiquetados e transportados em conformidade com normas e padrões internacionais aceitos e reconhecidos) e proibir definitivamente quando esta importação não for consentida pelos estados envolvidos ou quando esta for negociada com um estado parte que não realizou a adesão à Convenção.

meio ambiente, quando expostos a eles. A Convenção de Montego Bay , ou Convenção das Naçães Unidas sobre o Direito do Mar (UNCLOS), adotada em 1982, entrada em vigor 1994 e ratificada pelo Brasil 1988. In:SOARES, Guido F.S. Direito Internacional do Meio Ambiente: Emergência, Obrigações e Responsabilidades. São Paulo: Atlas, 2001. 


\subsection{Estrutura Básica da Convenção}

\subsection{1- Conferência das Partes (CoP)}

Criada no artigo 15 da Convenção e responsável por elaborações de políticas, a Conferência das Partes (CoP) tem por objetivo decidir sobre as emendas e mudanças nos anexos, bem como, também, proporcionar a harmonização das políticas e estratégias para o gerenciamento dos resíduos perigosos. Além disso, pode criar órgãos subsidiários para qualquer necessidade quanto a aplicação da Convenção de Basiléia. A Decisão I/1, criada na primeira conferência das partes, fundamenta a existência da mesma e cria a Regras de Procedimento (Rules of Procedure), dispondo de temas como: localização das reuniões, agenda de trabalho, posição jurídica dos Estados observadores, conduta das partes durante a vigência da Convenção e compilação de decisões entre os Estados.

Convém destacar que a $7^{\text {a }}$ Conferência (última realizada) foi a que mais gerou documentos e acompanha a consolidação do Protocolo sobre Responsabilidade e Compensação por Danos Resultantes de Movimentos Transfronteiriços de Resíduos Perigosos e seu Depósito, criado em 1999, e tem por objetivo estabelecer regras sobre responsabilidades e compensações por perigos causados por derrames de acidentes com resíduos durante exportação, importação ou disposição.

De forma simplificada, uma reunião de conferência das partes tem os seguintes passos: no início da sessão são eleitos entre os presentes e votantes, pois existem os países convidados, segundo uma distribuição geográfica eqüitativa e, em rodízio, um presidente, três vice-presidentes e um relator, que atuam como facilitadores da reunião. 0 presidente, ao ser investido em suas funções, não atua mais como representante de seu Estado de origem. A ele compete abrir e encerrar as reuniões, presidir as sessões, decidir sobre as questões de ordem e controlar os procedimentos das reuniões técnicas. Assim, ao decidir sobre uma questão de ordem ou sobre a natureza de um tema a ser discutido na conferência poderá o presidente ver seu tema contestado por um Estado-Parte presente. Deste modo, caso esta situação ocorra, tal pauta irá para votação de todos os estados presentes, em que a maioria decidirá pela permanência ou não do tema selecionado. 
Nas reuniões da conferência das partes, as decisões podem ser tomadas por maioria ou por consenso, conforme o caso. No entanto, o sistema dominante nas reuniões bianuais da Conferência das Partes (CoP) para medidas a serem adotadas, tem sido o sistema majoritário, em que a maioria dos presentes tem a decisão final sobre o assunto em pauta. Partindo deste princípio, temos aqui a violação do modo clássico de representatividade dos Estados no Direito Internacional, onde tínhamos que as palavras decisivas seriam dos Estados com poderes e majoritários, e não dos minoritários sem poderes. O sistema majoritário permite que os Estados em minoria e contra as obrigações internacionais tenham que obedecer, mesmo não consentindo com as regras postuladas. Neste caso, tal afirmação anterior mostra-se não sempre como o resultado final. 0 resultado final, neste caso, será decidido por todos os estados independente de seu poder econômico.

Sendo assim:

Um sistema de decisão sem voto, em que o silêncio geral testemunha a ausência de objeção ativa dos Estados membros, autoriza a adoção de um texto do qual uma autoridade aceite (portavoz de um grupo, presidente de um órgão) indicou o conteúdo. As decisões e recomendações adotadas por consenso têm exatamente o mesmo valor e alcance jurídico como se fossem votadas. ... A maioria dos Estados membros sabe que pode adotar o texto que lhe convém, mas teme que este permaneça letra morta se o concurso de uma maioria é indispensável a sua execução. Tal é o caso de toda a resolução adotada em matéria econômica à revelia dos países ocidentais. Esta maioria prefere então se associar a um texto aceitável a todos. Quanto à minoria, a ameaça de um voto que revelaria o seu isolamento e a colocaria numa situação embaraçosa leva-a, muitas vezes, a não se opor abertamente a um compromisso. ${ }^{45}$

A Conferência das Partes (CoP) também tem autorização para estabelecer órgãos subsidiários para a implementação da Convenção. Na primeira CoP realizada no Uruguai, em 1992, originou três órgãos derivados da Decisão I/2 . O grupo de trabalho em atividade é o Grupo de Trabalho para Elaboração de Diretrizes Técnicas acerca da Administração de Resíduos Perigosos, em que a equipe técnica mencionada tem por objetivo principal elaborar as características dos resíduos perigosos e propor as possibilidades de gestão para os países integrantes do tratado.

\footnotetext{
${ }^{45}$ DINH, N. et al., Direito internacional público. Lisboa. Fundação Calouste Gulbenkian, 1999. Tradução de FERREIRA, G. Natureza Jurídica e Definição dos Resíduos Perigosos. São Paulo: Tese de Mestrado. Universidade de São Paulo. 2003. 182p.
} 
Até a presente data a Convenção de Basiléia já reuniu os Estados - partes em sete conferências das partes. A primeira realizada no Uruguai em três de dezembro de 1.992 buscou não permitir que os países ricos realizassem movimentações transfronteiriça de resíduos para países pobres ou em desenvolvimento. Assegurar que a movimentação a partir de 1.992 ocorresse apenas com a garantia da recuperação e reciclagem ou a gestão de resíduos. A segunda conferência ocorreu em vinte e um de março de 1994, dois anos após a primeira reunião. Seu objetivo era além do de manter 0 controle da movimentação entre os países era que este somente ocorresse entre os países integrantes da OCDE. De este modo limitar e acompanhar cada vez mais o trânsito de resíduos ao longo destes dois anos. A terceira conferência ocorre um ano após, em dezoito de setembro de 1.995, realizando a criação de grupos técnicos para início das caracterizações dos resíduos. Neste momento histórico surgem os grupos de trabalho para busca da caracterização, reciclagem e recuperação dos rejeitos: metais e seus componentes pertencentes na convenção ao grupo R4, bifenilos policlorados, (PCBS, PCT, PBB), rejeitos infectantes pertencentes na convenção ao grupo H6.2, rejeitos tóxicos pertencentes na convenção ao grupo H11, rejeitos com características perigosas para disposição final pertencentes na convenção ao grupo H13. Tais nomenclaturas mencionadas são os nomes dos grupos de trabalho e correspondem ao código recebido pelo resíduo nos anexos da Convenção.

A quarta conferência surge em vinte e três de fevereiro de 1.998 pretende consolidar os resíduos componentes dos anexos primeiro, terceiro, oitavo e nono da convenção. A quinta conferencia aconteceu em seis de dezembro de 1.999 e pretendeu resgatar todas as pautas discutidas nas reuniões anteriores para projetá-los para a década que se iniciava e iniciar o avanço da consolidação do Protocolo de Compensações da Convenção que até a presente data ainda não entrou em vigor. A penúltima conferência das partes data de nove de dezembro de 2.002 e surgiu com 0 único propósito: todas as agendas discutidas até as cinco conferências anteriores devem buscar a implantação entre os países e dentro dos países que aderem ao tratado. Por fim a última conferência ocorrida em vinte e cinco de outubro de 2.004 almeja a implantação do Protocolo de Compensações e a difusão de tecnologias limpas e a consolidação dos inventários nacionais de resíduos. Todas estas ações estão em desenvolvimento conjuntamente com outros assuntos como: grupos de trabalho analisando o comportamento de resíduos componentes da convenção em seus anexos, busca de financiamentos por países interessados em uso de tecnologias limpas, a gestão 
dos resíduos em áreas afetadas por catástrofes ambientais, envio de informações dos pontos focais da convenção nos Estados - partes, etc.

\subsubsection{Secretariado}

O Secretariado criado durante as negociações da Convenção constitui-se de um mecanismo que tem por fim assegurar o intercâmbio de informações, assistência técnica, transferência tecnológica, monitoramento e controle dos movimentos transfronteiriços de resíduos perigosos. (informações contidas no artigo dezesseis item três da Convenção)

Os recursos para a manutenção do Secretariado têm procedência de um Trust Fund criado pelo Programa das Nações Unidas para o Meio Ambiente (PNUMA), após a aprovação do Governing Council. O Trust Fund é um mecanismo bem utilizado nos países industrializados para geração de recursos, como exemplos de Trust Fund têm, por exemplo, o Fundo Global da AIDS ou do Protocolo de Montreal para o combate a destruição da camada de ozônio.

O Trust Fund da Convenção de Basiléia, administrado pelo PNUMA, é aprovado por consenso pela Conferência das Partes e os recursos para sua manutenção direcionados para uma conta bancária em nome das Nações Unidas. O Trust Fund é um procedimento positivo no sentido de proporcionar a manutenção das atividades mínimas em relação ao que a Convenção propõe em seus artigos. Deste modo é assegurado recursos para a realização das conferências das partes, organização de reuniões técnicas dos grupos de trabalho, consolidação dos trabalhos resultantes destas reuniões, manutenção das atividades diárias do secretariado, contratação e manutenção dos funcionários para as atividades relacionadas com a Convenção, bem como, as informações contidas no endereço eletrônico da Convenção.

O Secretariado possui pouca autonomia, e tem o dever de realizar o que for acordado em Conferência das Partes. Disso resulta todas as ações sobre a Convenção, que serão decididas pelos Estados em reuniões da $\mathrm{CoP}$, mas nem mesmo diante de sua ação limitada torna-se menos importante a partir do momento que todas as tarefas administrativas são gerenciadas por este órgão. 
3- Direito Internacional e Direito Internacional Ambiental e a Convenção

A Convenção de Basiléia sobre o Controle de Movimentos Transfronteiriços de Resíduos Perigosos e Disposição Final, como já mencionamos, idealizou -se no início de 1981 sob os auspícios do Programa das Nações Unidas para o Meio Ambiente (PNUMA) na reunião de Montevidéu de Peritos em Legislação Ambiental. Em seguida, na reunião do Cairo sobre Gerenciamento Seguro de Resíduos Perigosos, elaborou-se o rascunho do acordo global sobre o assunto. Em 1989 foi adotada e reconhecida como um documento de referência mundial na Conferência de Plenipotenciários, em Basiléia. A Convenção deve ser um instrumento que representa o esforço internacional para eliminar o trânsito de resíduos com periculosidade ambiental.

Convém relembrar em termos de obrigações gerais que $A$ Convenção de Basiléia sobre o Controle de Movimentos Transfronteiriços de Resíduos Perigosos e Disposição Final contempla, dentre outros, os seguintes compromissos: a necessidade de consentimento prévio, por escrito, por parte dos países importadores dos resíduos autorizados de importação; a adoção de medidas adequadas de minimização da geração de resíduos, levando em consideração aspectos sociais, tecnológicos e econômicos; a administração ambientalmente saudável de resíduos perigosos e seu depósito; a adoção de medidas internas para a implementação da Convenção; a possibilidade de movimentação entre Estados - Partes e não Partes somente mediante acordo de cooperação; a exigência que a movimentação transfronteiriça atenda as normas e padrões internacionais aceitos e reconhecidos para embalagem, etiquetagem e transporte; a permissão para a movimentação transfronteiriça de resíduos perigosos, desde que os resíduos em questão sejam necessários como matéria-prima para as indústrias de reciclagem e recuperação no estado de importação. ${ }^{46}$

Considera-se na Convenção como tráfico ilegal 47 movimentos realizados sem notificação com ausência de consentimento, consentimento falsificado ou fora de conformidade com a documentação exigida para que seja liberado o transporte transfronteiriço entre os cento e sessenta

${ }^{46}$ Convenção da Basiléia sobre o controle de movimentos transfronteiriços de resíduos e seu depósito. Secretaria do Meio Ambiente, São Paulo, 1997. Artigo 4.

47 Tráfico ilícito ou tráfico ilegal, segundo a Convenção, compreende o transporte entre estados ou países sem o consentimento, notificação ou em conformidade de ambas as partes envolvidas na remoção e gerenciamento do resíduo perigoso. 
e cinco Estados Partes envolvidos no status de ratificação de abril de 2005. As informações da movimentação entre Estados devem sempre ser de conhecimento prévio do secretariado da Convenção. A Convenção tem atingido seus objetivos em termos de propor uma organização na movimentação de resíduos perigosos e em um crescente intercâmbio de informações e tecnologias, inclusive quanto à redução na geração de resíduos.

A Convenção de Basiléia sobre o Controle de Movimentos Transfronteiriços de Resíduos Perigosos e Disposição Final propõe, desta forma, ser um suporte para a busca do gerenciamento integrado dos resíduos perigosos no País. Vejamos, por exemplo, o dever de minimizar a geração de resíduos perigosos. Além de consagrada no preâmbulo da Convenção, essa obrigação manifesta-se no artigo Quatro (2) (a), nestes termos:

Cada parte deverá tomar medidas adequadas para assegurar que a geração de resíduos perigosos e outros resíduos em seu território seja reduzida a um mínimo, levando em consideração aspectos sociais, tecnológicos e econômicos.

Partindo da busca de tomar medidas adequadas para assegurar a geração de resíduos perigosos, surgem as propostas de internalização da Convenção, como o Plano Estratégico para Implementação da Convenção de Basiléia para 2010, que devem assegurar que os resíduos sejam quantificados e depositados o mais próximo possivel do local onde foram gerados, a fim de que se reduza sua movimentação transfronteiriça.

No entanto, assegurar que o resíduo seja depositado o mais próximo possível da fonte geradora, a fim de que se reduza à movimentação é um objetivo que não pode ser perseguido isoladamente, sem alguma referência técnica que permita avaliar efetivamente se é o gerenciamento mais apropriado, ao invés de enviá - lo para outro Estado, onde a infra-estrutura para seu gerenciamento é mais adequada. Desta forma, o Plano Estratégico de Metas para 2010 ao disponibilizar tecnologias limpas deverá contemplar esta vertente de análise não detalhada na Convenção.

Destacamos na Convenção, o princípio da administração ambientalmente saudável dos resíduos perigosos, que haverá de ser entendido, nos termos do artigo dois (8) e artigo dez (1) em que: 
Como a tomada de todas as medidas práticas para garantir que os resíduos perigosos ou outros resíduos sejam administrados de maneira a proteger a saúde humana e o meio ambiente de efeitos nocivos que possam ser provocados por esses resíduos.

Como podemos analisar trata-se de uma definição vaga da qual somente é possível deduzirmos que esse princípio refere-se a uma determinada maneira de operar e agir, procedimentos escolhidos de acordo com critérios que não danifiquem a vida humana e a do meio ambiente sem alterações na ordem ambiental da utilização dos recursos e por novos caminhos na ordem econômica vigente mundialmente.

Do mesmo modo, podemos indicar a necessidade de uma verticalização da Convenção, por intermédio das leis nacionais, em seu artigo quatro (7) (a) (c), ao exigir que as Partes estabeleçam um sistema de autorizações para realização de transportes e solicitando também o documento de movimento entre os Estados envolvidos. Observe abaixo os artigos da Convenção em sua íntegra:

Proibir todas as pessoas sob sua jurisdição nacional de transportarem ou depositarem resíduos perigosos ou outros resíduos, a não ser que essas pessoas estejam autorizadas ou tenham permissão para realizar esses tipos de operações. ${ }^{48}$ Exigir que os resíduos perigosos e outros resíduos se façam acompanhar de um documento de movimento desde o ponto no qual tenha início um movimento transfronteiriço até o ponto de depósito. ${ }^{49}$

Em atendimento a estes artigos mencionados anteriormente nasceram o Plano Estratégico , 0 Protocolo de Compensações e as decisões III/2, II/3, IV/4. Em relação as decisões, respectivamente, requer o Grupo Técnico o desenvolvimento de critérios para caracterização da periculosidade; prorrogação do mandato do Grupo Técnico para o desenvolvimento de diretrizes para o tratamento físico - químico de resíduos perigosos como para a reciclagem de compostos metálicos; dispõe sobre a criação de centros regionais ou sub-regionais para treinamento e transferência de tecnologia no âmbito do manejo de resíduos perigosos e outros resíduos e a

\footnotetext{
${ }^{48}$ Convenção de Basiléia artigo 4 (7) (a). Em anexo neste trabalho.

${ }^{49}$ Convenção de Basiléia artigo Quatro (7) (c). Em anexo neste trabalho.
} 
minimização de sua geração. A Decisão II/12 da $2^{\mathrm{a}}$ Reunião das Partes da Convenção de Basiléia proíbe, após 31/12/97, a movimentação transfronteiriça de resíduos perigosos de países da Organização para Cooperação e Desenvolvimento Econômico (OCDE) para países não membros da OCDE ou em desenvolvimento. Esta Decisão II/12 foi transformada em emenda à Convenção pela $3^{\text {a }}$ Reunião da Conferência das Partes. Mas mesmo diante de todos estes instrumentos jurídicos não nos iludamos que não possa ocorrer que qualquer país ainda tente realizar a movimentação transfronteiriça sem atender os procedimentos criados.

Quanto à classificação dos resíduos, em seu Anexo I, a Convenção apresenta as categorias de resíduos a serem controlados em dois grupos: no primeiro, a periculosidade, já mencionada, mas ligada à origem geradora do resíduo e, no segundo, a periculosidade do elemento que o constitui. Assim para a primeira classificação temos, por exemplo, os resíduos resultantes de mercúrio. Para a segunda classificação podemos mencionar os materiais que contém arsênico (categoria $Y 24$ ), chumbo (categoria Y 31) ou amianto (categoria Y 36).

No entanto, o Anexo III complementa as características que devemos observar nos resíduos, como, por exemplo, ser explosivo (característica H 1) , inflamável (característica H 3) , venenosa (característica H 6.1) ou tóxico (característica H 10). Resta, porém, uma questão debatida por Ferreira 50 :

\begin{abstract}
A questão que se debate gira em torno das quantidades mínimas desses elementos a serem encontrados na matéria antes que ela possa preencher um dos requisitos para classificar-se como resíduo perigoso nos termos da Convenção. É como se indagássemos da seguinte forma: basta que haja, por exemplo, independente de quantidade, mas com as características do Anexo III, mercúrio (Y 29) ou amianto (Y 36) numa determinada matéria que se destina a depósito para que ela possa ser considerada resíduo perigoso?
\end{abstract}

Por esta consideração, na Quarta Conferência das Partes, a Decisão IV/9 , introduziu dois novos Anexos, o VIII e o IX, os quais contém, respectivamente, relação de resíduos e a forma de

${ }^{50}$ FERREIRA, G. Natureza jurídica e definição dos resíduos perigosos. Tese de Mestrado. Faculdade de Direito da Universidade de São Paulo. 2003. 
medições do mesmos para caracterizá - los como perigosos e não perigosos nos termos do artigo $1(1)(a)$ :

\begin{abstract}
Os resíduos relacionados neste Anexo são caracterizados como perigosos nos termos do Artigo $1^{10}$, parágrafo 10, alínea (a) desta Convenção e sua inclusão neste Anexo não impedem o uso do Anexo III, para demonstrar que um resíduo não é perigoso. (caput, Anexo IV).Os resíduos contidos no Anexo não serão os resíduos cobertos pelo Artigo $1^{\circ}$, parágrafo $1^{\circ}$, alínea (a) desta Convenção, a menos que contenha elementos do Anexo I em concentração tal que apresentem características do Anexo III. (caput Anexo IX)
\end{abstract}

Por fim não poderíamos deixar de mencionar o Princípio da Precaução, do Poluidor-Pagador e da Cooperação correlacionados com a Convenção da Basiléia. Neste sentido usaremos a classificação mencionada por Derani:

Identifico três princípios fundamentais: da Cooperação, do Poluidor-Pagador, da Precaução (kooperationsprinzip, verursacherprinzip, vorsorgepinzip). ${ }^{51}$

O Princípio da Cooperação, segundo Derani, não é exclusivo do Direito Ambiental, já era existente na Estrutura do Direito do Estado Social. Ele orienta a formação de políticas que visem o bemcomum, inerente ao Estado. O princípio é percebido na Convenção de Basiléia, quando em suas estratégias para o ano de 2003/2004 prevê a transferência de tecnologia e informações para instalação de cadeias limpas de produção. Convém lembrar que este tema é fruto das diretrizes 2003/2004, permanecendo para a próxima fase 2010.

O segundo princípio denominado Poluidor-Pagador, não contemplado na Convenção, mas internalizado nas políticas públicas ambientais brasileiras, é existente quando, por exemplo, pedimos após a realização de uma inspeção técnica com comprovação do dano, o termo de ajuste de conduta ou, ainda, após a não realização do mesmo, diante dos prazos estipulados, poderá estar sujeita a sanções. Observe a citação de Derani, comprovando nossa afirmação:

51 In:DERANI, C. Direito Ambiental Econômico. São Paulo: Max Limonad. 2001. pg. 160. 
O Princípio do Poluidor-Pagador visa a internalização dos custos relativos externos de deterioração ambiental. Tal traria, segundo Derani, um cuidado maior com o potencial poluidor da produção, na busca de uma satisfatória qualidade do meio ambiente. Pela aplicação deste princípio impõe - se ao sujeito econômico que se nesta relação possa causar um problema ambiental, deverá arcar com os custos da diminuição ou afastamento do dano. (grifos da autora) 52

O terceiro princípio conhecido como o da Precaução, ou prevenção para alguns autores, é contemplado na Convenção desde o instante de preparação de seus artigos, pois tem por finalidade gerenciar o movimento de transporte de resíduos, como prevenção a danos ambientais ou humanos. Para que o leitor entenda nossa posição, compreendemos o Princípio da Prevenção como sendo:

Precaução contra o risco que objetiva prevenir já uma suspeição de perigo ou garantir uma suficiente margem de segurança de linha de perigo. A Convenção contempla este princípio, desde seu nascimento. (grifos da autora) ${ }^{53}$

Mas, todos os mecanismos mencionados da Convenção são na realidade caminhos encontrados para a busca de uma regulação do transporte transfronteiriço entre os estados. Entretanto, não nos iludamos, pois antes de seu nascimento e após a sua entrada em vigor, os transportes indevidos de cargas tóxicas irão desaparecer. $O$ que é importante neste contexto é acreditar que a Convenção além de ser um suporte, para a temática de proteção da saúde humana e ambiental através do trânsito de cargas não seja ignorado.

Passaremos apresentar a seguir para o capítulo três chamado: Ação governamental para a implantação da Convenção da Basiléia no Brasil onde queremos alertar ao leitor que se faz necessário pensar na gestão dos resíduos industriais através da demonstração das principais leis que orientam a gestão de resíduos e a convenção de Basiléia no país. Divulgaremos ao leitor a situação da coleta, transporte e disposição final dos rejeitos industriais no Brasil, bem como as

52 In:DERANI, C. Direito Ambiental Econômico. São Paulo: Max Limonad. 2001. pg. 160.

53 In:DERANI, C. Direito Ambiental Econômico. São Paulo: Max Limonad. 2001. pg. 169. 
atuações da Coordenadoria de Segurança Química brasileira e a atual situação da busca de um inventário nacional de resíduos industriais. Serão expostos, para finalizar o capítulo, o significado e a atuação dos Centros Nacionais de Tecnologias Limpas no Brasil funcionando como transmissores de tecnologias limpas para o setor empresarial do país. A pergunta central de nossa reflexão neste próximo capítulo é a seguinte:

Será que a Convenção é uma iniciativa que influenciará efetivamente políticas públicas para resíduos industriais nacionais? 


\section{CAPÍTULO III - AÇÃO GOVERNAMENTAL PARA A IMPLANTAÇÃO DA CONVENÇÃO DA BASILÉIA NO BRASIL}

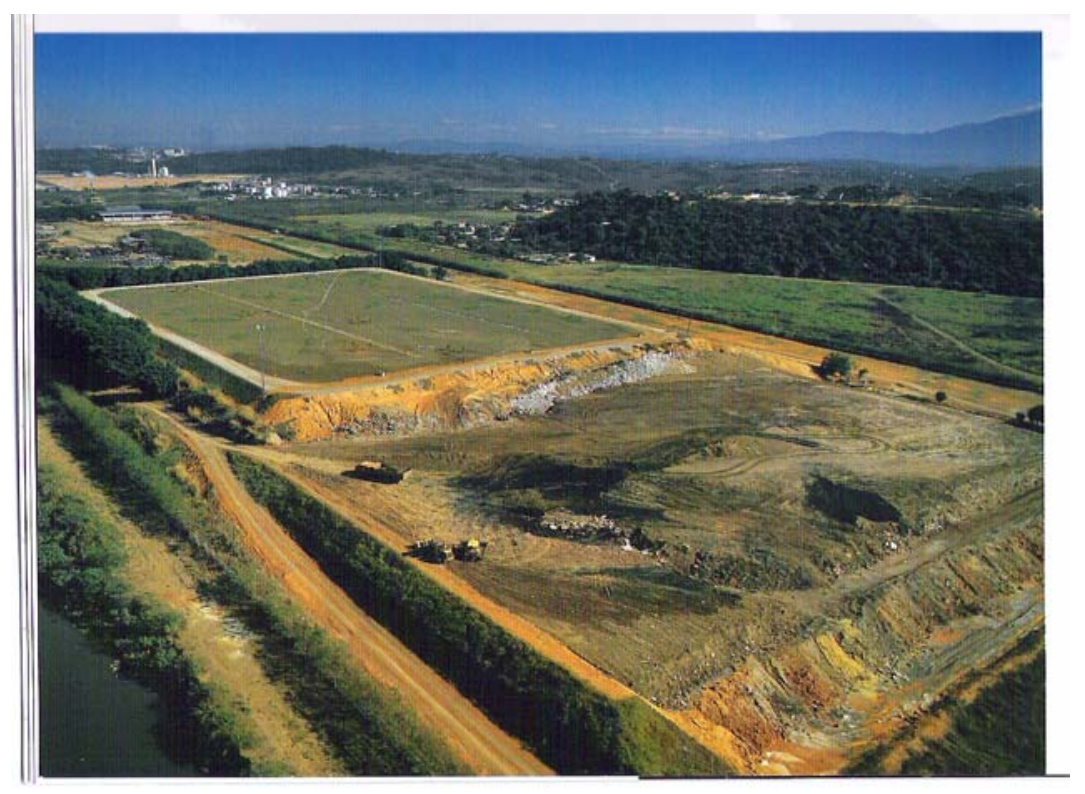

Unidade de aterro da Tribel para tratamento de resíduos industriais, em Belford Roxo, Rio de Janeiro, 2003.

O capítulo III intitulado de "Ação governamental para a implantação da Convenção da Basiléia no Brasil", em que comentaremos logo de início a respeito do corpo legislativo brasileiro referente à gestão dos resíduos sólidos industriais e a relação destas leis com a Convenção de Basiléia. Abordaremos também sobre as informações da Coordenadoria de Segurança Química no País, retratando as ações do Estado diante da gestão dos rejeitos, dentre esses, os industriais. A Coordenadoria comenta as atuações do governo brasileiro na busca da internalização desta 
segurança química. Este primeiro momento do texto deixa claro ao leitor a importância da legislação nacional, que serve como mecanismo de articulação para a internalização da Convenção e a aceitação do Brasil em não compactuar com o transporte ilegal de resíduos.

No segundo momento, não poderemos deixar de informar ao leitor a situação, até a presente data, da gestão dos resíduos industriais no País. Deste modo, responderemos as seguintes questões: Qual é a geração de resíduos industriais no Brasil? Quais são os possíveis caminhos para o gerenciamento dos rejeitos industriais no Brasil? O que são os inventários nacionais de resíduos? E quais são os planos da Convenção para o Brasil até a próxima década?

Para finalizarmos o capítulo, explicaremos a atuação dos Centros Nacionais de Tecnologias Limpas (centros fomentadores da difusão de tecnologias que assessoram a gestão de resíduos industriais). E daremos uma certa ênfase no primeiro parágrafo desse capítulo na questão: Por que não partir para o auxílio das técnicas, hoje conhecidas como "tecnologias limpas", para a gestão dos resíduos industriais?

\section{1- O Corpo Legislativo Brasileiro e a Convenção de Basiléia}

Ao aderir à Convenção de Basiléia sobre o Controle de Movimentos Transfronteiriços Perigosos e seu Depósito, o governo brasileiro se associou a um instrumento que considera positivo, uma vez que regulamenta o trânsito de resíduos baseado no princípio do consentimento prévio, onde procura coibir o tráfico ilícito e prevê a intensificação da cooperação internacional para a gestão adequada desses resíduos conforme consta no artigo primeiro, parágrafo um, do Decreto 875 de dezenove de julho de 1993 que promulga a Convenção no Brasil. Abaixo observe a íntegra do artigo:

Ao aderir à Convenção de Basiléia sobre o Controle de Movimentos Transfronteiriços de Resíduos Perigosos e seu Depósito, o governo brasileiro se associa a um instrumento que considera positivo, uma vez que estabelece movimentos - baseados no princípio do consentimento prévio e explícito para a importação e o trânsito de resíduos perigosos - e procura coibir o tráfico ilícito e prevê a intensificação da cooperação internacional para a gestão adequada desses resíduos. 
Assinar a Convenção de Basiléia e promulgá-la em decreto constituiu apenas o primeiro passo para o controle do processo negociador da movimentação de resíduos. Após este passo é necessário que o estado inicie a introdução de normas em sua legislação interna que sejam observadas em todo 0 território brasileiro. Mais do que nunca, neste momento, os Estados devem abrigar os artigos e os anexos das convenções ratificadas para que o tratado consiga cumprir seu propósito de existência. No caso da Convenção de Basiléia, o propósito de sua existência é a garantia de que o movimento de transporte de resíduos ocorra com o consentimento prévio entre países e a busca deste consentimento prévio entre suas unidades federativas em nível de legislação nacional. 54

Em relação às legislações nacionais pertinentes a internalização da Convenção da Basiléia, detalharemos o decreto 5.098 de três de junho de 2004, que criou o Plano Nacional de Prevenção e Resposta Imediata para Acidentes com Produtos Químicos Perigosos e a norma NBR 13221 da Associação Brasileira de Normas Técnicas (ABNT), que regulamenta o transporte de resíduos, e a resolução do Conselho Nacional do Meio Ambiente (CONAMA) de vinte e três de dezembro de 1996 que especifica os procedimentos brasileiros para solicitação de importação de resíduos. 0 leitor poderá encontrar no anexo deste trabalho as leis do corpo legislativo brasileiro correlacionadas com a Convenção de Basiléia e o objetivo principal destas perante a gestão dos resíduos industriais. 0 leitor poderá perceber também a legislação referente à movimentação de resíduos industriais no País. No entanto, não podemos deixar de comentar detalhadamente as leis já mencionadas, pois estão intimamente relacionadas ao transporte, o que consolida a existência da Convenção.

DECRETO DOS ATOS DO PODER EXECUTIVO número 5.098, de três junho de 2004.

O decreto mencionado permite avançar internamente na busca da gestão saudável das substâncias potencialmente ameaçadoras ao meio ambiente e à saúde humana. Após quase dez anos da assinatura da Convenção, a legislação nacional e o governo propuseram através deste decreto a harmonização do controle de acidentes em nível nacional para o transporte inadequado de resíduos perigosos. Houve também a criação do Plano Nacional de Prevenção, Preparação e Resposta

\footnotetext{
${ }^{54}$ No caso do Brasil, o Presidente da República tem o poder de celebrar tratados, convenções e atos internacionais, no entanto, é de competência do Congresso Nacional resolver definitivamente os tratados, acordos ou atos internacionais que acarretem encargos ou compromissos gravosos ao patrimônio nacional. Conforme: Constituição da República Federativa do Brasil artigo quarenta e nove, I e artigo oitenta e quatro, inciso VIII. 1988.
} 
Rápida a Emergências Ambientais com Produtos Químicos Perigosos (P2R2), sem esquecer que este plano incluirá em seus princípios do desenvolvimento da prevenção, da precaução, e o poluidor -pagador diante de acidentes. 0 leitor a seguir observa o parágrafo primeiro deste decreto que menciona a interface com a Convenção:

\footnotetext{
Considerando os compromissos internacionais decorrentes da assinatura ou ratificação mediante decretos legislativos de instrumentos que tratam do controle de produtos e resíduos químicos, tais como: a Convenção de Basiléia sobre os Movimentos Transfronteiriços de Resíduos Perigosos. Considerando as declarações e textos como a Agenda 21 da Conferência das Nações Unidas sobre o Meio Ambiente e o Desenvolvimento (Rio-1992), que trata em seus Capítulos 19 e 20, respectivamente, da gestão ambientalmente segura, da prevenção do tráfico ilícito de produtos químicos tóxicos e resíduos tóxicos, e o Plano de Implementação da Cúpula Mundial sobre Desenvolvimento Sustentável ocorrida em Joanesburgo, África em 2002, que determinou a elaboração da Abordagem Estratégica para a Gestão Internacional de Substâncias Químicas estabelece-se à criação neste referido decreto do Plano Nacional de Prevenção, Preparação e Resposta Rápida a Emergências Ambientais com Produtos Químicos Perigosos - P2R2, com 0 objetivo de prevenir a ocorrência de acidentes com produtos químicos perigosos e aprimorar 0 sistema de preparação e resposta a emergências químicas no País. 55
}

Norma número 13221 da Associação Brasileira de Normas Técnicas (ABNT)

A norma NBR 13221 denominada "Transporte de Resíduos", publicada em 2000, especifica as condições necessárias para o transporte de resíduos, de modo a proteger a saúde pública , evitando danos ao meio ambiente. Esta norma se aplica ao transporte de resíduos, por meio terrestre, conforme classificados na portaria 204 do Ministério dos Transportes. Regulamenta o transporte federal rodoviário de produtos perigosos. Substituída pela Resolução n 204/ANTT de 12/02/2004 (DOU 31/05/2004) mencionando em seu objetivo a importância de aplicar esta norma aos resíduos relacionados na Convenção de Basiléia. Elucida, também, a necessidade de informar sobre 0 resíduo (suas características) e sobre o gerador (atividade, razão social, endereço, etc). 0 leitor observa, a seguir, o parágrafo dois desta norma que menciona a interface com a Convenção:

${ }^{55}$ Fonte pesquisada o próprio decreto. 
Esta norma especifica as condições necessárias para o transporte de resíduos, de modo a evitar danos ao meio ambiente e proteger a saúde humana. Aplica-se esta norma também aos resíduos perigosos segundo a definição da Convenção de Basiléia (adotada pelo Brasil em trinta de dezembro de 1992) ${ }^{56}$

Resolução número 023/96 do Conselho Nacional do Meio Ambiente (CONAMA):

A resolução CONAMA de vinte e três de dezembro de 1996 organiza, em território nacional, a movimentação transfronteiriça de resíduos. Realizada concomitantemente com a norma da ABNT número 10.004 (Classificação de Resíduos) a classificação de resíduos embora em seu texto não mencione em nenhum momento a existência desta norma.Tal norma deixa bem claro que a importação somente ocorrerá caso o Instituto Brasileiro do Meio Ambiente e dos Recursos Naturais Renováveis (IBAMA) e o órgão estadual de meio ambiente da unidade federativa emitam pareceres técnicos favoráveis. Observe os artigos cinco e seis da resolução a seguir informando sobre as exigências mínimas para a movimentação transfronteiriça:

As empresas que pretendam importar resíduos para reciclagem ou reaproveitamento por terceiros, poderão fazê-lo, desde que atendam às exigências desta resolução e informem ao IBAMA quais empresas reprocessadoras que se responsabilizarão, formalmente, pela reciclagem ou reaproveitamento do resíduo importado, apresentando cópia do contrato firmado. As exigências previstas deverão também atender aos procedimentos de notificação prévia, conforme determinado no art. $6^{\circ}$, Anexos V-A e V-B, da Convenção de Basiléia (Anexo nove), quando o país exportador ou importador for parte. ${ }^{57}$

Contudo, a existência de leis, resoluções e normas citadas anteriormente, não são suficientes para a gestão adequada de todos os resíduos industriais gerados em território brasileiro. No entanto, não podemos desmerecê-las, pois as normas, em seu nascimento, são regulamentações do Estado aos tratados e leis vigentes e cabe ao ele assumir esta posição, formulando-as para a preservação do interesse público. Neste momento, convém lembrar o que se define por interesse público:

\footnotetext{
${ }^{56}$ Fonte pesquisada a própria norma.

${ }^{57}$ Fonte: a própria lei no endereço eletrônico http://www.agenciaambiental.go.gov.br. Acesso em 28/10/2005.
} 
Por interesse público compreende-se o que permite manter as estruturas essenciais da coletividade, sejam as estruturas políticas (instituições), econômicas (bem-estar), sociais (estabilidade), culturais (valores e patrimônio) ou ecológicas. ${ }^{58}$

A organização e a aceitação de um tratado reflete não somente o interesse do Estado, mas teoricamente, antes de tudo, o interesse do povo. Ao assinar um tratado o Estado garante com sua estrutura um quadro de técnicos, leis, órgãos que permitam garantir o interesse público representado pelo Estado. A partir do momento em que o Estado defende o interesse público para uma melhor qualidade de vida, ele ganha em sentido duplo, no caso da Convenção da Basiléia, pois mantém uma segurança perante aos resíduos químicos e, ao mesmo tempo, está aberto a investimentos estrangeiros que somente chegam no País caso este adote medidas de caráter preservacionista. Neste momento podemos concluir que o Estado mantém com as leis a ordem e gera recursos financeiros apostando em atitudes de ordem ecológica.

Embora alguns dos produtos tóxicos perigosos estejam enquadrados em legislações nacionais brasileiras, cujos objetivos precípuos são promover o controle sobre a sua produção, importação, exportação, comercialização e uso de forma a minimização dos danos à saúde humana e ao meio ambiente, existe ainda uma parcela que se coloca à margem da legalidade nos Estados, especificamente no caso brasileiro. No entanto, não podemos esquecer que o aumento do tráfico ilegal de produtos tóxicos perigosos é uma função direta de controle do Estado e cabe a ele elaborar mecanismos de coibição com o intuito de livrar a população do perigo da exposição a estes resíduos.

Reafirmando mais uma vez esta posição do Estado em resguardar o interesse público surge a citação de Ribeiro mencionando a função do mesmo diante da manutenção da ordem:

Além disto, o Estado tem por função a regulação da vida humana em ações envolvendo o meio ambiente quando estabelece normas técnicas, leis, multas, critérios de licenciamento ambiental ${ }^{59}$.

\footnotetext{
58 LE PRESTE, Philippe. Ecopolítica internacional. São Paulo: Senac, 2000. pg.64

${ }^{59}$ RIBEIRO, W.C Trabalho e ambiente: novos profissionais ou nova demanda? In: Revista electrónica de geografía y ciencias sociales .Universidad de Barcelona, Vol. VI, num. 119 (98), um de agosto de 2002.
} 
Deste modo reafirmamos que são necessários todos os aparatos das leis somados às técnicas para que as políticas públicas brasileiras de resíduos sejam eficientes nos gerenciamentos dos resíduos industriais no País e possam assim fundamentar a Convenção em território nacional. Convém lembrar a citação de Derani ao enfatizar a existência de normas como, por exemplo, a Convenção de Basiléia, que reflete um esforço internacional na busca da regulação da movimentação internacional e que no momento perpassa por uma escala menor, aqui considerada como a escala dos Estados-nacionais:

\footnotetext{
Quando nos defrontamos com a norma jurídica, devemos ter em mente que não estão nela regulamentados meramente desejos e ambição por comportamentos ou programas. A norma incorpora a tarefa de procurar reter no tempo o que o cotidiano não é ou não foi capaz de perpetuar. Nela estão presentes valores e idéias que remetem a uma nostalgia coletiva por uma sociedade ideal. ${ }^{60}$
}

Torna-se necessário, ao nosso ponto de vista, a existência de leis, como a Convenção de Basiléia para representar o interesse público diante da movimentação transfronteiriça e mais do que isso para permitir que livremente ocorra a transferência de rejeitos tóxicos entre os países. Não nos iludamos que as relações de forças entre países ricos e pobres se tornariam sem limites a partir do momento em que não exista nenhuma lei garantindo que esta não possa ocorrer a movimentação transfronteiriça de rejeitos. A Convenção de Basiléia é um artifício em forma de lei para evitarmos que as questões ambientais relacionadas aos resíduos sejam excluídas da agenda de discussões da ordem ambiental internacional.

\section{1- Legislação Nacional de Resíduos Industriais}

De acordo com o artigo três, inciso IV, da Lei 6938/81, considera-se poluidor "a pessoa física ou jurídica, de direito público ou privado, responsável, direta ou indiretamente, por atividade causadora de degradação ambiental". O vocabulário poluidor é amplo e inclui aqueles que diretamente causam o dano ambiental, seja industrial, madeireiro, minerador entre outros. Havendo mais de uma fonte geradora, aplica-se o princípio da solidariedade entre os co-poluidores, apreendido mediante

\footnotetext{
${ }^{60}$ DERANI, C. Direito Ambiental Econômico. São Paulo: Max Limonad. 2001. pg. 42.
} 
interpretação do artigo 1.158 do Código Civil e artigos 258,259 e 275 do novo Código Civil. Tais normas visualizam a degradação ambiental como um fato danoso único, indivisível, pressupondo que, em conseqüência da impossibilidade de fragmentação do dano, o nexo causal é comum. ${ }^{61}$

Além da Lei de Crimes Ambientais, a Constituição Federal de 1988, mencionada anteriormente, dispõe de capítulos sobre o gerenciamento de resíduos industriais. 0 artigo vinte e três, por exemplo, relata a competência dos municípios no tocante ao combate da poluição em suas diversas formas. $O$ inciso três do capítulo 225 menciona que condutas lesivas ao meio ambiente estarão sujeitas às sanções penais. Somando-se à Constituição Federal Brasileira e a Lei de Crimes Ambientais, o País está regulamentado com leis federais, decretos e normas técnicas no tema.

O leitor poderá perceber em anexo neste trabalho que mencionamos a legislação referente à movimentação de resíduos industriais no País. No entanto, não podemos deixar de comentar detalhadamente as mencionadas, pois estão intimamente relacionados com o transporte, itens que consolida a existência da Convenção. Cabe salientar que aqui estaremos apenas enumerando as leis que envolvam resíduos industriais.

LEI FEDERAL número 7.802 de 11 de julho de 1989

A lei mencionada tem por objetivo regulamentar desde a pesquisa e fabricação dos agrotóxicos, bem como sua comercialização, aplicação, controle, fiscalização e também o destino da embalagem. Em vigência através da regulamentação do decreto de número 4.074 de quatro de janeiro de 2002 define o que vem a ser considerado por lei como agrotóxico e, também, relata que fica proibido por lei o uso de defensivos agrícolas para os quais não existam tratamentos eficazes de sua gestão em território nacional. $\mathrm{O}$ artigo mais relevante desta lei para nosso trabalho é quanto às embalagens de defensivos após a sua reutilização. A lei é bem clara, o fabricante deve mencionar ao comprador 0 destino final mais adequado para as mesmas e além disto sua simbologia deve alertar quanto aos problemas de saúde humana e impacto ambiental decorrente do uso inadequado do agrotóxico ou a não utilização da tecnologia final recomendada. Observe abaixo a pena aplicável à lei:

61 STEIGLEDER, A. Aspectos Jurídicos da Reparação de Áreas Contaminadas por Resíduos Industriais. Revista de Direito Ambiental: São Paulo, Editora Revista dos Tribunais. Janeiro-março 2003, ano oito, número 29, pp 1-336. 
O empregador, profissional responsável ou o prestador de serviço, que deixar de promover as medidas necessárias de proteção à saúde e ao meio ambiente, estará sujeito à pena de reclusão de 2 (dois) a 4 (quatro) anos, além de multa de 100 (cem) a 1.000 (mil) Maior Valor de Referência (MVR). Em caso de culpa, será punido com pena de reclusão de 1 (um) a 3 (três) anos, além de multa de 50 (cinqüenta) a 500 (quinhentos) MVR. ${ }^{62}$

LEI FEDERAL número 9.055 de 01 junho de 1995.

A lei mencionada tem por objetivo limitar a extração, a industrialização, a utilização e comercialização, o transporte de asbesto e amianto, e sua importação, sendo possível ocorrer apenas mediante aprovação do Departamento Nacional de Produção Mineral (DNPM), em vigência através da regulamentação do decreto de número 2.350 de quinze de outubro de 1995. Seu artigo primeiro menciona a proibição, em todo o território nacional, da extração, produção, industrialização, utilização e comercialização da actinolita, amosita (asbesto marrom e o abesto branco), antofilita, crocidolita (amianto azul) e da tremolita, variedades minerais pertencentes ao grupo dos anfibólios, bem como dos produtos que contenham estas substâncias minerais. Neste sentido, deve-se tomar precauções no uso do amianto e abesto, ainda utilizado no setor de construção civil no País. A fiscalização é vital para a não ameaça à saúde humana em contato com este material. $\mathrm{O}$ anexo III da Convenção denominado Lista de características perigosas menciona sobre:

As substâncias ou resíduos passíveis de provocar morte ou sérios danos, ou efeitos adversos à saúde humana se ingeridos ou inalados, ou pelo contato dos mesmos com a pele, possuem a característica perigosa é, portanto, controlados pela Convenção.

Paralelamente, as leis observam a resolução CONAMA número 348 de dezesseis de agosto de 2004 declarando que o amianto, segundo a Convenção de Basiléia, deve ser considerado um

\footnotetext{
${ }^{62}$ Artigo 16 da LEI № 7.802, de onze de julho de 1989 que dispõe sobre a pesquisa, a experimentação, a produção, a embalagem e rotulagem, o transporte, o armazenamento, a comercialização, a propaganda comercial, a utilização, a importação, a exportação, o destino final dos resíduos e embalagens, o registro, a classificação, o controle, a inspeção e a fiscalização de agrotóxicos, seus componentes e afins, e dá outras providências. Fonte: a própria lei no endereço eletrônico http://www.agenciaambiental.go.gov.br. Acesso em 28/10/2005.
} 
resíduo de ordem perigosa e de importação proibida, controlada caso necessário pelos órgãos competentes. $O$ amianto é utilizado com freqüência pela construção civil para a fabricação de telhas e demais objetos. A seguir observe o trecho da resolução:

\footnotetext{
Considerando o previsto na Convenção de Basiléia sobre o Controle de Movimentos Transfronteiriços de Resíduos Perigosos e seu Depósito, promulgada pelo Decreto Federal número 875, de dezenove de julho de 1993, prevê em seu artigo primeiro, item um, alínea "a" e anexo $\mathrm{I}$, que considera o resíduo de amianto como perigoso e pertencente à classe $Y 36.63$
}

\section{PORTARIA INTERMINISTERIAL N 053, DE 01 DE MARÇO DE 1979.}

Estabelece normas relativas ao tratamento e disposição final dos resíduos sólidos. Esta portaria foi parcialmente revogada pela resolução CONAMA, número seis de dezenove de setembro de 1991 no que se refere aos resíduos gerados nos portos, aeroportos, terminais ferroviários e rodoviários e estabelecimentos prestadores de serviços de saúde, que de acordo com suas disposições, deveriam ser obrigatoriamente incinerados. A resolução CONAMA mencionada anteriormente liberou-os desta obrigação, atribuindo aos estados a aprovação da alternativa adotada para a disposição final desses resíduos. Desta portaria devem ser destacados: a proibição do lançamento de resíduos sólidos em cursos de água, lagos e lagoas, salvam na hipótese de necessidade de aterro de lagoas artificiais e quando for devidamente autorizados, a proibição da alimentação de animais com lixo "in natura" e a exigência de que os resíduos sólidos de natureza tóxica, bem como aqueles que contenham substâncias inflamáveis, corrosivas, explosivas, radioativas e outras consideradas prejudiciais, sofram tratamento ou acondicionamento adequado no próprio local de produção e nas condições estabelecidas pelo órgão estadual de controle da poluição.

\section{PORTARIA INTERMINISTERIAL № 019, DE 29 DE JANEIRO DE 1981.}

A portaria mencionada tem por objetivo evitar a contaminação do ambiente por bifenil policloradosPCB's (comercialmente conhecidos como Askarel, Aroclor, Clophen, Phenoclor, Kanechlor e outros), devido aos efeitos nocivos que esses compostos causam ao Homem e animais. O seu artigo primeiro informa que fica proibido em território nacional o uso de bifenil policorados e que em caso

\footnotetext{
${ }^{63}$ Preâmbulo da Resolução Conama número 348 de 16 de agosto de 2004.
} 
de utilização deste, o mesmo deve ser substituído por substância equivalente, sem que haja impactos à saúde humana e ambiental. As empresas, no território brasileiro, que fazem uso deste insumo e produzem rejeito, devem tomar as medidas necessárias para o transporte deste para outros países, garantindo a administração saudável dos mesmos.

A partir da data da publicação desta Portaria, fica proibida, em todo Território Nacional, a implantação de processos que tenham como finalidade principal à produção de Bifenil Policlorados - PCB's. As empresas usuárias de equipamentos elétricos deverão considerar, nas especificações de novos capacitadores de potências, a aquisição de equipamentos que não utilizem PCB's. ${ }^{64}$

A gestão destes resíduos e o controle do mesmo para a movimentação transfronteiriça, mencionados no mesmo artigo, caso necessário, ficam por responsabilidade dos órgãos estaduais do meio ambiente.

Cabe aos órgãos estaduais do meio ambiente a vigilância e fiscalização para o cumprimento das normas contidas nesta Portaria. ${ }^{65}$

A instrução normativa da Secretaria do Meio Ambiente, de dez de junho de 1983, disciplina as condições a serem observados no manuseio, transportes, armazenamento de bifenilas policloradas orientando, portanto, a portaria principal sobre 0 assunto.

Resolução número 006 do Conselho Nacional do Meio Ambiente (CONAMA)

A respeito das resoluções federais sobre resíduos industriais, destacam-se novamente as provenientes do Conselho Nacional do Meio Ambiente. A resolução de número seis de quinze de junho de 1988 merece nossa atenção, uma vez que obriga as indústrias geradoras de resíduos, conforme os respectivos critérios, de apresentar ao órgão ambiental competente informações sobre a geração, características e destino final de seus resíduos. Os mapeamentos destas informações

\footnotetext{
${ }^{64}$ Fonte: a própria lei no endereço eletrônico http://www.agenciaambiental.go.gov.br. Acesso em 28/10/2005.

${ }^{65}$ Fonte: a própria lei no endereço eletrônico http://www.agenciaambiental.go.gov.br. Acesso em 28/10/2005.
} 
são benéficos em dois sentidos: primeiro, na geração de uma base de dados que permita auxiliar na construção do perfil nacional de resíduos sólidos industriais gerados no País, e segundo, a visualização pelos órgãos estaduais de meio ambiente dos focos de geração de resíduos para então realizar a fiscalização e o controle necessário para que as indústrias cumpram a gestão dos rejeitos. Observe a seguir 0 artigo três que relata sobre a gestão de defensivos agrícolas e o quarto que relata a gestão de PCB's:

\begin{abstract}
As entidades públicas e/ou privadas que possuam estoques agrotóxicos fora de condições de uso proibido, deverão apresentar ao órgão ambiental competente dentro de 90 (noventa) dias, a partir da publicação desta Resolução, o inventário destes estoques, na forma definida no Anexo I. As concessionárias de energia elétrica e empresas que possuam materiais e/ou equipamentos contaminados com Bifenilas Policloradas - PCB'S, bem como estoques e/ou equipamentos fora de uso, contendo óleos ascaréis, deverão apresentar ao órgão ambiental competente, dentro de 60 (sessenta) dias, a partir da publicação desta Resolução, o inventário destes estoques, na forma definida no Anexo I. 66
\end{abstract}

No anexo o leitor poderá encontrar a relação de resoluções do Conama referentes a resíduos industriais.

Norma número NBR 10.004/04 da Associação Brasileira de Normas Técnicas (ABNT)

As normas da ABNT também servem como instrumentos para o gerenciamento de resíduos no País. Aqui neste trabalho abordaremos duas destas normas com mais detalhamento. No anexo, o leitor poderá encontrar a relação de resoluções da ABNT referentes a resíduos industriais.

A classificação dos resíduos no Brasil obedece à norma NBR 10.004/04 denominada "Resíduos Sólidos", publicada em 1987 e revisada em 2004, em que sistematiza os resíduos quanto aos seus riscos potenciais ao meio ambiente e à saúde pública, e inclui além dos resíduos sólidos, os semisólidos, lodo, borra e determinados líquidos, como por exemplo, solventes, óleos lubrificantes e PCBS ou bi-fenilos policlorados. A NBR 10.004/87 era focada na classificação dos resíduos para disposição em aterro. A atual tem essas visões ampliadas, voltadas para a classificação, com vista

\footnotetext{
${ }^{66}$ Fonte a própria norma foi consultada.
} 
ao gerenciamento dos resíduos independente da sua destinação final. A segregação dos resíduos na origem, ou seja, na fonte geradora, constitui aspecto extremamente importante, junto com 0 desenvolvimento dos procedimentos corretos no processo de classificação, elevando a potencialidade de reaproveitamento e reciclagem de um determinado resíduo.

A classificação para o gerenciamento dos resíduos na nova NBR 10.004/04 estabelece dois grupos: os da Classe I Perigosos e os da Classe II Não perigosos, removendo a antiga classificação de resíduos Classe III (inertes). Outro aspecto importante é a questão do laudo de classificação, do qual devem fazer parte à indicação da origem do resíduo com a identificação das matérias-primas e insumos, como etapa decisiva para a classificação de um determinado resíduo, bem como a descrição do processo de segregação e a descrição do critério adotado na escolha de parâmetros analisados, quando for o caso, incluindo os laudos de análises laboratoriais.

A NBR 10004/2004 trouxe maior detalhamento quanto aos códigos anteriormente utilizados. Neste ponto, a norma está mais clara, pois contém um roteiro mais detalhado de maneira a facilitar 0 entendimento das etapas a serem percorridas pelo usuário. Uma das formas para enquadrar um resíduo como perigoso está na elaboração de Laudo de Classificação baseado exclusivamente na identificação do processo produtivo, por profissional habilitado, quando do enquadramento do resíduo nas listagens dos Anexos A e B constantes da NBR 10004, onde estão detalhados os resíduos perigosos de fontes não específicas e os resíduos perigosos de fontes específicas, respectivamente.

Na seqüência da aplicação da norma, um resíduo é considerado perigoso quando apresenta pelo menos uma das seguintes propriedades: corrosividade, reatividade, inflamabilidade, toxicidade ou patogenicidade. Ao definir resíduos perigosos, a norma faz menção aos seus diferentes anexos, bem como às demais normas relacionadas a NBR 10.004/04 para o estabelecimento de uma correta classificação. São os casos da NBR 10005/04 relativos ao procedimento para obtenção de extrato lixiviado de resíduos sólidos, a NBR 10006/04 relativa ao procedimento para obtenção de extrato solubilizado de resíduos sólidos, e a NBR 10007/04 referente à amostragem de resíduos sólidos.

Neste último aspecto, o roteiro é completo e define todas as questões pertinentes. Um ponto importante é a inclusão da amostragem e a análise contemplando frações voláteis dos resíduos na norma de lixiviação. Com a norma anterior você podia ter ali um resíduo a ser classificado para 
análise com substâncias sendo volatilizadas, sem que fossem submetidas à identificação. Na versão atual da norma esses aspectos ficam bem mais claros.

Outra ação na esfera governamental, mas não relacionada apenas com a geração de leis para regulamentação do transporte é a criação do Plano Nacional de Segurança Química no país reforçando ainda mais a importância do tema e a busca de soluções adequadas para possíveis acidentes.

\section{2- Segurança Química no Brasil}

A implementação de uma política de segurança química no Brasil está a cargo do Ministério do Meio Ambiente (MMA) e dos demais órgãos sob a sua responsabilidade, sendo, portanto, a questão tratada na esfera federal. O MMA, através da portaria interministerial número 319 , de vinte e sete de dezembro de 2000, criou a Comissão Coordenadora do Plano de Ação em Segurança Química (COPASQ), com o objetivo de elaborar o Perfil nacional de substâncias químicas que permite 0 passo da elaboração do Plano Nacional de Segurança Química(PNGSQ) ,com vistas à implementação dos princípios, diretriz e prioridades enunciadas no Capítulo 19 da Agenda 21, mencionadas no capítulo primeiro deste trabalho.

O ponto de partida para a criação da COPASQ foi o documento denominado Declaração da Bahia e a carta de Linhas Prioritárias de Ação do Fórum Internacional de Segurança Química (FISQ) elaboradas em 2000 onde, diversos segmentos da sociedade compreendidos por empresas, associações representativas do setor de utilização de insumos químicos em grandes quantidades e o setor público, reuniram-se para iniciar o processo de formação de diretrizes nacionais para a busca da criação de um modelo de segurança química para o Brasil.

O Fórum de Segurança Química é uma das ações no sentido da divulgação do tema segurança química no Brasil. Foi neste fórum elaborada a diretriz denominada Declaração da Bahia, pois o evento ocorreu em Salvador que contém os princípios da fundamentação da atuação da Coordenadoria de Segurança Química (COPASQ). Foi deste encontro que surgiuram às intenções que mais tarde tornar-se-iam o decreto 5.098, de três de junho de 2004 abordando Plano Nacional 
de Prevenção, Preparação e Resposta Rápida a Emergências Ambientais com Produtos Químicos Perigosos.

O último evento do Fórum de Segurança Química ocorrido em novembro de 2003, na Tailândia e intitulado de IV Foro Intergovernamental De Segurança Química-(FISQ) foi organizado para atender: à expansão e aceleração da avaliação internacional dos riscos químicos, à harmonização da classificação e da rotulagem dos produtos químicos, ao intercâmbio de informações sobre os produtos químicos, à implantação de programas de redução de riscos, ao fortalecimento das capacidades e potenciais nacionais para o manejo de produtos químicos, à prevenção e o tráfico ilegal de produtos perigosos.

As diretrizes trabalhadas no fórum influem diretamente na Convenção de Basiléia. Ao detectarmos a periculosidade de um produto químico, e que incluem dentre os seus objetivos a prevenção e redução de riscos de impactos decorrentes de acidentes ambientais relacionados às atividades químicas que podem ocasionar contaminação ao homem e ao meio ambiente, podemos em parte, prever os tipos de resíduos gerados do uso deste insumo e propor medidas de prevenção simultâneas.

Paralelamente aos fóruns de segurança as atividades da COPASQ são desenvolvidas. Atualmente a Coordenadoria é composta por instituições dos setores públicos, privados ou e de organizações não governamentais. De acordo com o regimento aprovado, a COPASQ atua com a seguinte composição: Presidência - MMA; Vice-presidência - MS; Secretaria Executiva - MMA; Plenária entidade com indicados oficiais; Coordenadorias Técnicas e Sub -Coordenadorias.

Como as linhas de ação inseridas na COPASQ são amplas, englobando diferentes questões relacionadas à segurança química, o mecanismo adotado para a execução e acompanhamento das ações foi a criação de Coordenadorias Técnicas para cada uma das 16 linhas de ação prioritárias estabelecidas. Dentre os dezesseis convém destacar, pois estão mais relacionadas com resíduos: 
Terceira prioridade da COPASQ a Elaboração do Perfil Nacional de Substâncias Químicas:

A COPASQ tem trabalhado, com uma de suas linhas, na confecção de um Perfil Nacional da Gestão de Substâncias Químicas (PNGSQ), que irá fornecer uma visão ampla da atuação do Brasil no que tange à gestão de substâncias químicas, implementando medidas preventivas e corretivas para a redução de riscos ocasionados por estas substâncias à saúde humana e ao meio ambiente. Em resumo, o Perfil Nacional pretende demonstrar o cenário da gestão das substâncias químicas no Brasil e permitir, a partir dele, a elaboração de políticas públicas que venham a otimizar o sistema de gestão, sanando lacunas e corrigindo processos industriais. Previsto para 2003, a fim de ser divulgado na IV Foro Intergovernamental de Segurança Química, este ainda não fora concluído. 0 mesmo é componente dos Perfis Nacionais de Gestão de Substâncias Químicas já produzidos por governos de outros países como, por exemplo, Venezuela, Chile, Colômbia, Equador, Paraguai, Peru e Trindade e Tobago.

Sexta prioridade da COPASQ a criação do Sistema Globalmente Harmonizado (GHS) para Classificação e Rotulagem de Substâncias Químicas:

O cenário brasileiro demonstra a inexistência de sistema nacional sobre classificação, rotulagem de produtos químicos, exceto em algumas poucas áreas, como mencionamos anteriormente a lei federal de rotulagem, classificação de embalagens de defensivos agrícolas. Neste caso este grupo pretende estender a importância da rotulagem para outras substancias químicas amplamente utilizadas. Neste sentido os usuários destas substâncias estarão informados também do tipo de resíduo que terão em mãos após a utilização do insumo químico.

Sétima prioridade da COPASQ a criação do Sistema para Prevenção do tráfico ilegal de produtos tóxicos perigosos:

Considerando o universo atual dos produtos químicos perigosos circulantes no País que se acham englobados em qualquer tipo de legislação cujo objetivo visa o controle (restrições diversas) ou mesmo à proibição de uso e à comercialização, entendemos que existe a necessidade premente de especificar um grupo de produtos que estariam abrangidos pelo presente sistema. Assim sendo, como etapa desta prioridade é o de definir um grupo de produtos pelo seu(s) uso(s) principal (is) e os riscos associados a este(s) uso(s) para depois esboçar o sistema de prevenção ao tráfico. № 
entanto não podemos esquecer que a Convenção de Basiléia aqui é o ponto de partida para este trabalho, pois existe a necessidade de um estudo mais pormenorizado sobre a situação do tráfico destes produtos no Brasil, visando à identificação das linhas gerais desse tipo de comércio, quais sejam: o universo dos produtos envolvidos, os locais de ocorrência, as medidas e sistemas já existentes objetivando o controle do trânsito.

Já existe como meta para a internalização da convenção a tradução do Manual de Implementação da Convenção de Basiléia e distribuí-lo para os órgãos e entidades envolvidas com a geração, exportação, importação e/ou disposição de resíduo perigoso, bem como, outros setores privados e órgãos de governo. O Instituto Brasileiro do Meio Ambiente e dos Recursos Naturais Renováveis (IBAMA) está elaborando um Manual de Procedimentos em Casos de Riscos Ambientais visando facilitar 0 trabalho dos fiscais em ações rotineiras e emergências que somente vem a somar com as ações mencionadas anteriormente da COPASQ.

\section{3- O Gerenciamento dos Resíduos Industriais no Brasil}

Os resíduos industriais constituem, no Brasil, um motivo de preocupação das autoridades e órgãos ambientais, seja devido às quantidades que vem sendo geradas, principalmente como resultado da elevada concentração industrial em algumas regiões do País, como pela carência de instalações e locais adequados para o tratamento e destino final destes resíduos.

A realização sistemática de inventários de resíduos industriais pode fornecer informações importantes que ampliam o entendimento dos problemas relacionados com a geração de resíduos, auxiliando na identificação de ações prioritárias para seu gerenciamento e de oportunidades para sua minimização ou não geração e, ainda, para a adoção de tecnologias mais limpas de produção, com vistas à eficiência das operações e ao melhor desempenho ambiental das empresas. A tabela dez a seguir demonstra o resumo das informações já levantadas para os inventários de alguns estados. 
Tabela 3 - Geração de Resíduos Sólidos Industriais no Brasil - Estados Selecionados

\begin{tabular}{|c|c|c|c|c|}
\hline Unidades da Federação & \multicolumn{4}{|c|}{ Geração de Resíduos (t./ano) } \\
\hline & Classe I & Classe II ${ }^{2}$ & Classe III $^{3}$ & Total \\
\hline $\mathrm{SP}^{1}$ & 535.615 & 25.038 .167 & 26.619 .677 \\
\hline $\mathrm{RJ}^{2}$ & 293.953 & \multicolumn{2}{|c|}{5.768 .562} & 6.062 .515 \\
\hline $\mathrm{RS}^{3}$ & 205.326 & 1.404 .732 & 1.635 .690 \\
\hline $\mathrm{PR}^{4}$ & 634.543 & \multicolumn{2}{|c|}{15.106 .393} & 15.740 .936 \\
\hline $\mathrm{PE}^{5}$ & 12.622 & 1.325 .791 & 4.071 & 1.342 .483 \\
\hline $\mathrm{GO}^{6}$ & 4.405 & \multicolumn{2}{|c|}{1.486 .969} & 1.491 .374 \\
\hline
\end{tabular}

1.CETESB. Inventário de Resíduos Industriais, 1996.

2.FEEMA . Relatório de Atividades do Projeto Controle Ambiental, 2000.

3.FEPAM. Relatório sobre a geração de resíduos sólidos industriais na região do Guaíba, 2002.

4.IAP. Inventário Estadual dos Resíduos Sólidos Industriais, 2002.

5.CPRH- Inventário de Resíduos Industriais,2001.

6. Agência Ambiental. 2003

Apesar dos dados constantes dos inventários estaduais disponíveis no momento estarem desatualizados (São Paulo, por exemplo, data do ano de 1996 quase dez anos de utilização dos dados), ou serem parciais (Goiás, Pernambuco, por exemplo) e não terem sido elaborados com a mesma metodologia, o que inviabiliza comparações, a geração de resíduos sólidos (Classe I) já soma 1.686.464 ton./ano apenas para os estados listados na tabela 6. Ausências importantes na tabela são os estados de Minas Gerais e Bahia, respectivamente, terceiro e sexto PIB dos estados brasileiros, e detentores de parques industriais. Outro ponto que chama a atenção é quanto ao número de resíduos sólidos industriais (Classe I) apontada pelo Estado do Paraná, quando comparado, com os estados de São Paulo e Rio de Janeiro. O fato de que o Estado de São Paulo, responsável por quase $50 \%$ do valor bruto da produção industrial nacional e detentor de um parque industrial diversificado, com forte presença da indústria química, alimentos, bebidas, petroquímica,

\footnotetext{
${ }^{1}$ A classificação dos resíduos é regulamentada pela Associação Brasileira de Normas Técnicas (ABNT), através da NBR 10004, em que resíduos classe I - Perigosos: apresentam periculosidade ou uma das seguintes características: inflamabilidade, corrosividade, reatividade, toxicidade e patogenicidade. Ex: baterias, produtos químicos, etc.

${ }^{2}$ A classificação dos resíduos é regulamentada pela ABNT, através da NBR 10004, em que resíduos classe II - Não Inertes: não se enquadram como resíduos classe I - Perigosos ou resíduos classe III - Inertes e podem ter as seguintes propriedades: combustibilidade, biodegradabilidade ou solubilidade em água. Ex: matéria orgânica e papel.

${ }^{3}$ A classificação dos resíduos é regulamentada pela ABNT, através da NBR 10004, em que resíduos classe III - Inertes: não têm constituinte algum solubilizado em concentração superior ao padrão de potabilidade de águas. Ex: rochas, tijolos, vidros e certos plásticos e borrachas que não são decompostos prontamente.
} 
metalurgia básica, máquinas e equipamentos e automobilística, apresente uma geração de resíduos de Classe I quase 15\% menor que o Estado do Paraná. Esta situação serve para ilustrar as debilidades nas estatísticas sobre geração e gerenciamento de resíduos no País.

Vale mencionar que as metodologias para a realização de inventários de resíduos industriais no Brasil privilegiam os maiores geradores, e o universo da amostra se concentra nas grandes empresas que apresentam cargas de poluentes mais elevadas. No entanto, pequenas empresas também são fontes significativas de ameaça ao meio ambiente e à saúde pública. Mesmo não se dispondo de estatísticas sobre estes geradores (pela dispersão geográfica ou, muitas vezes, pela informalidade destas empresas), estima-se que as pequenas e médias empresas sejam responsáveis por até um terço da geração de resíduos perigosos no mundo. Razões não faltam para que essas empresas apresentem baixo desempenho ambiental: falta de informação sobre 0 tema, falta de conhecimento da legislação vigente, baixo nível de especialização da mão-de-obra, falta de acesso a crédito para tecnologias limpas entre outros.

As mudanças ainda são lentas na diminuição do potencial poluidor do parque industrial brasileiro, principalmente no tocante às indústrias mais antigas, que continuam contribuindo com a maior parcela da carga poluidora gerada e elevado risco de acidentes ambientais sendo, portanto, necessário altos investimentos de controle ambiental e custos de despoluição para controlar a emissão de poluentes, do lançamento de efluentes e do depósito irregular de resíduos perigosos. As indústrias tradicionalmente responsáveis pela maior produção de resíduos perigosos são: metalúrgicas, indústrias de equipamentos eletro-eletrônicos, fundições, indústria química e indústria de couro e borracha.

As empresas estão caminhando para a completa internalização dos custos da conservação ambiental, implicando a necessidade de mudanças significativas nos padrões de produção, comércio e consumo. As vantagens de um desempenho ambiental adequado são diversificadas, traduzindo em maior aceitação de produtos e serviços no mercado consumidor, eliminação de penalidades e multas, redução e diluição de custos de minimização de impactos e recuperação de danos ambientais, e diminuição do consumo de matéria - prima, água e energia. Além disso, temos 
redução da possibilidade de ocorrência de acidentes ambientais, otimização do trabalho, preservação de questões de responsabilidade civil ou criminal, melhoria do relacionamento da empresa com o órgão ambiental e com a comunidade, comprometimento com a responsabilidade social empresarial, melhoria da imagem da empresa perante a opinião pública e o aumento da credibilidade da empresa como fornecedora eficiente e confiável.

Em diversos setores industriais a introdução de práticas de prevenção à poluição e a busca de tecnologias limpas têm demonstrado que a filosofia da prevenção à poluição não somente é uma ferramenta efetiva para um gerenciamento ambiental mais eficiente, ou ecoeficiente, como também traz uma série de benefícios econômicos. Os processos industriais que no presente geram resíduos são fontes de poluição assim como fontes de despesas até a etapa de disposição final. Pensar no gerenciamento dos resíduos industriais e no processo industrial que envolvam a redução de resíduos é a nova fase de um sistema de busca de divisas contabilizando os custos naturais. Neste sentido, a reciclagem, a reutilização e as tecnologias limpas são ferramentas para que a produção desenfreada permaneça. Deste modo concordamos com a afirmação de Dupuy:

\footnotetext{
A lógica do capitalismo baseada no consumo desenfreado com o propósito de gerar lucros e crescimento deu um efeito proporcional em gerar desperdícios, degradações do meio ambiente e fez aparecer raridades com as quais o capitalismo deve contar daqui a diante. A água e 0 ar eram bem abundantes e gratuitos (...) é preciso hoje reproduzir o ar e a água, quer dizer, reciclá-los e isso custa caro. A indústria deverá preocupar-se cada vez mais em proteger, pelo menos em parte, o meio ambiente. ${ }^{67}$
}

Nos últimos dez anos, apesar do aumento do número de empresas que tratam de forma adequada os resíduos industriais produzidos em fábricas, o quadro de gerenciamento integrado não atinge todo o setor industrial brasileiro. Poderíamos relembrar inúmeros casos neste trabalho quanto a não atuação com responsabilidade ambiental por parte do setor industrial brasileiro. No entanto, lembraremos do caso das quatro empresas do Pólo Industrial de Manaus, pertencente à Região Norte e que ainda formula seu inventário de dados para futuro gerenciamento de resíduos - Showa

\footnotetext{
${ }^{67}$ DUPUY, J. Introdução a crítica da ecologia política. Rio de Janeiro: Civilização Brasileira, 1980. 112p. pg.18.
} 
do Brasil, Yamaha, Philips e Sansung - que discutem a destinação de trezentas toneladas de resíduos perigosos de Classe I. Todos os resíduos gerados na Zona Franca de Manaus tinham como endereço a Companhia Brasileira Bauxita sediada no Pará, que atualmente está sob embargo dos órgãos federais, dentre eles o Instituto Brasileiro do Meio Ambiente e dos Recursos Naturais Renováveis (IBAMA) filial no estado do Pará. A fim de evitar o crime de co-responsabilidade, tais empresas cessaram o envio de seus rejeitos. Tais resíduos, desde 2001, estão estocados nas empresas aguardando o destino final. Além da busca da melhor disposição, essas empresas devem atentar para o correto tráfego estabelecido com empresas licenciadas ambientalmente no País. ${ }^{68}$

Outro caso conhecido é o da empresa Rodhia que já gastou mais de US\$ oito milhões para corrigir problemas herdados na compra da empresa Clorogil, em 1976. Instalada em Cubatão, tal empresa mantinha depósitos irregulares espalhados pela Baixada Santista Paulista, Estado de São Paulo, contaminados com hexaclorobenzeno. 69

Não podemos deixar de mencionar os locais de certos estados da federação brasileira que sem motivos convenientes tornam-se depósitos irregulares de resíduos industriais. Um destes casos é a da região de Ulianópolis, no Pará, que virou depósito irregular de resíduos industriais de grandes empresas que atuam no mercado brasileiro. Observe a citação noticiada na época de descobrimento da disposição irregular:

Não há mais como esconder: o Pará virou uma grande lixeira tóxica do País, que manda para Ulianópolis, a 390 quilômetros de Belém, todo o rejeito químico industrial produzido por grandes empresas nacionais e multinacionais, tais como: Petrobrás, Vale do Rio Doce, Texaco, Shell,

\footnotetext{
${ }^{68}$ Saneamento Básico na Internet. Lixo Tóxico preocupa empresas da ZFM. www.saneamentobasico.com.br . São Paulo. Internet, 29/10/2002

${ }^{69}$ Em 1993, um grupo de toxicologistas identificou quarenta e cinco pesticidas e produtos químicos industriais como destruidores endócrinos ou como suspeitos de serem destruidores endócrinos. Em 1995, o Conselho de Administração do Programa das Nações Unidas para o Meio Ambiente (PNUMA) aprovou uma lista com doze poluentes orgânicos persistentes (POPS) e iniciaram um processo para a criação de uma Convenção Internacional para a redução e a eliminação da produção, venda e uso destes poluentes orgânicos persistentes. Os doze POPS aprovados inicialmente são a) pesticidas: DDT, Aldrin, Chlordano, Dieldrin, Endrin, Heptacloro, Mirex e Toxapheno; b) produtos industriais: bifenilas policloradas (PCBs) e hexaclorobenzeno (que também é pesticida); c) subprodutos de processos industriais e queima incompleta (produção não intencional): dioxinas e furanos. In: Jornal Gazeta Mercantil. Passivos trouxeram Problemas. São Paulo. 24/02/2000. Na publicação "Crimes Ambientais Corporativos no Brasil" em 2002, é mencionado o caso Rodhia e mais outros casos de impactos a saúde e ao meio ambiente decorrentes de resíduos.
} 
Pepsi-Cola, Philips da Amazônia, além de outras dezenas de grupos econômicos e siglas que pouco estão se importando com o destino de seus dejetos que saem de suas garagens e pátios. São Paulo, Rio Grande do Sul, Paraná, Minas Gerais, Rio de Janeiro e até de Manaus despacham seus lixos para Ulianópolis tida como o município de maior produção de grãos do Estado. Caminhões e carretas trazem dezenas de milhares de toneladas de resíduos de petróleo, gasolina e graxa contaminadas, resíduos de óxido de chumbo e amônia, lâmpadas e luvas contendo mercúrio, borra de tinta, solventes e acetona, além de material contaminado por produtos farmacêuticos e biológico de uso veterinário. Ou melhor, vinham trazendo, porque a empresa que armazena e que deveria incinerar adequadamente este lixo, foi fechada há um mês pelo IBAMA e pela Secretaria de Meio Ambiente do Pará. 70

O que é mais curioso diante dos casos mencionados e outros que não vamos enumerar neste trabalho é que se demoram anos para que os depósitos irregulares de resíduos industriais sejam descobertos pelas autoridades competentes, colocando a população à exposição de substâncias desconhecidas por um longo período e impactando por anos o meio ambiente com esta situação de risco. No final das contas os maiores prejudicados são a população local e o meio ambiente, pois mesmo diante dos reparos previstos para tais situações estes não são suficientes para devolver equilíbrio da biota local.

As empresas têm recorrido, como alternativa, à estocagem de seus resíduos de produção em suas propriedades, criando os denominados aterros industriais, instalações de landfarming ou ainda galpões de armazenamento controlados quando não conseguem realizar a disposição nos aterros industriais existentes no País. No entanto, esta é uma medida provisória, pois as empresas não podem permanecer por anos com seus resíduos estocados em suas unidades de produção colocando em risco a população de trabalho no local ou, ainda, impedindo que a produção industrial não cresça devido ao uso daquela área para disposição de resíduos.

Outra alternativa para a gestão de resíduos industriais é a incineração. A incineração é uma tecnologia que poucas empresas possuem acesso por este motivo às indústrias processam seus resíduos e prestam também serviços a outras indústrias. Os incineradores no Brasil destinados ao

\footnotetext{
${ }^{70}$ ABETRE - Associação Brasileira de Empresas de Tratamento de Resíduos. Pará virou lixeira do Brasil, com a usina de Ulianópolis. www.abetre.com.br . São Paulo. Internet, 4/08/2002.
} 
tratamento dos resíduos mencionados somam nove, unidades localizadas, respectivamente, no Estado do Rio de Janeiro (dois), em São Paulo (um), em Minas Gerais (três) e no Paraná (três).

No entanto, não podemos esquecer do lado perigoso da incineração que é quando ocorrem as emissões tóxicas, liberadas pelos incineradores mais modernos, que são formados por três tipos de poluentes perigosos para o ambiente e para a saúde humana: os metais pesados, os produtos de combustão incompleta e as substâncias químicas novas formadas durante 0 processo de incineração. Equipamentos de controle de poluição podem remover alguns desses metais das emissões, mas mesmo os mais modernos não eliminam com segurança todos eles. Ou seja, os metais pesados não desaparecem, são transferidos para as cinzas ou para os filtros, que acabam geralmente sendo aterrados.

Outro aspecto traiçoeiro da incineração ocorre pela formação de produtos químicos durante 0 processo de combustão, que podem apresentar toxidade como, por exemplo, as dioxinas e os furanos. Estes produtos são formados pela recompilação de fragmentos químicos de lixo parcialmente queimados nos fornos dos incineradores e depositados nas chaminés e/ou nos dispositivos controladores de poluentes evitando assim sua difusão. As dioxinas são formadas quando materiais contendo cloro, como o PVC, são queimados (na presença de matéria orgânica). Isso, muitas vezes, é ignorado, tornando-se alta a toxicidade das cinzas resultantes do processo de incineração. A destinação final de forma segura e ambientalmente correta dessas cinzas exige controle. Manejadas de forma inadequada, elas representam riscos para a saúde e o meio ambiente a curto e longo prazo. Em seqüência é possível visualizar a figura 1 (um) com a imagem do incinerador da empresa Teris que trata seus resíduos e também o de outras indústrias interessadas. 


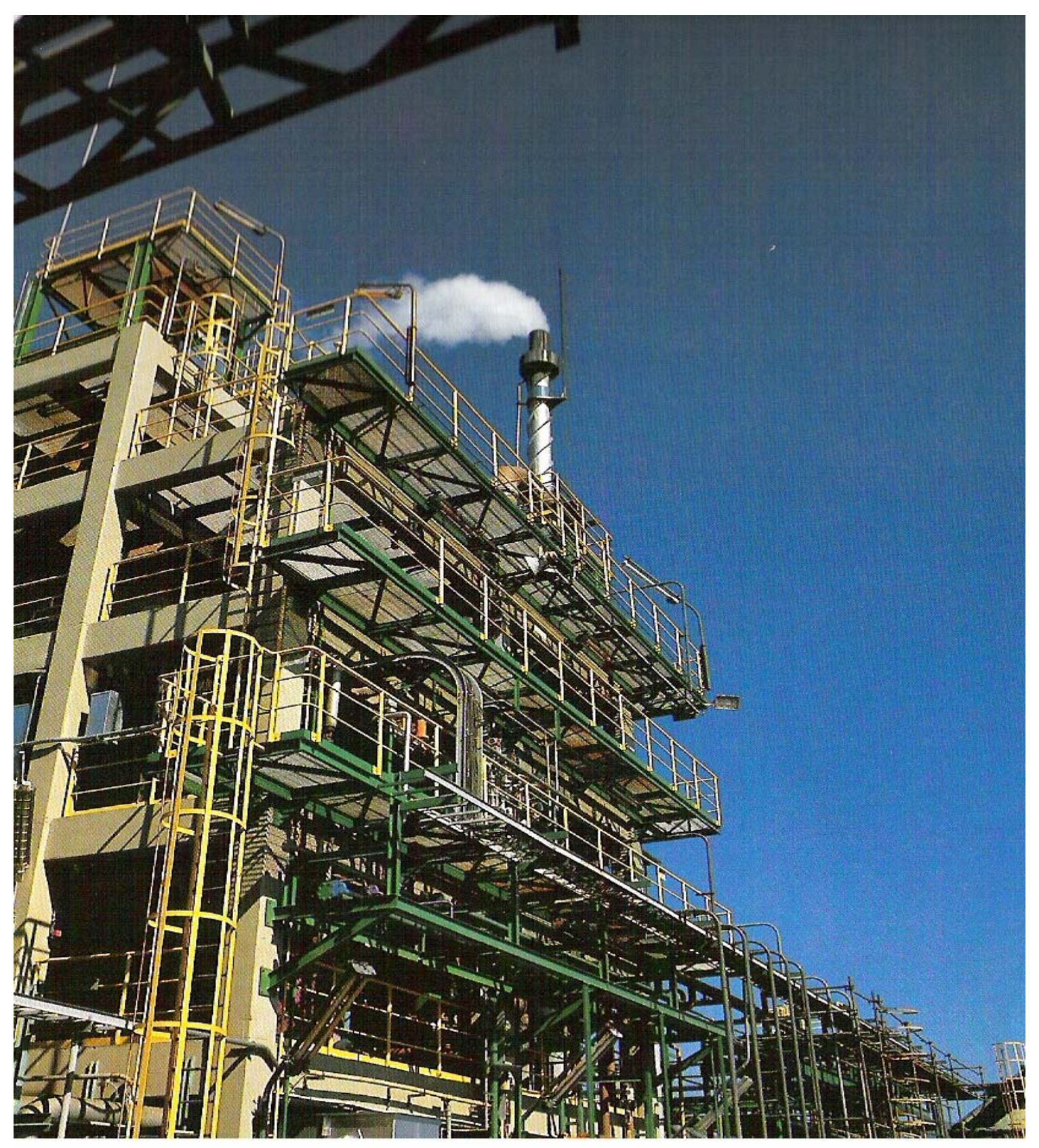

Figura 1 - Incinerador da empresa Teris, São Paulo, Brasil.

Fonte: Revista Notícias, Federação das Indústrias de São Paulo (FIESP), Setembro de 2002. 
Resíduos predominantemente orgânicos como borras oleosas, resinas, borras de tinta, e que são mencionados na Convenção de Basiléia, encontram no co-processamento uma alternativa de destino final. Outros resíduos como os PCBs ${ }^{71}$, chumbo, resíduos de curtumes, metais pesados, mercúrio e óleo lubrificante usado, também, encaixam-se nesta alternativa de gerenciamento no Brasil. O co-processamento, de uma forma simplificada, resume-se na utilização de resíduos industriais como combustíveis fósseis para fornos de cimento. 0 co-processamento de resíduos perigosos em fornos de cimento é praticado no País, sujeito ao licenciamento local, tornando-se uma alternativa no gerenciamento de resíduos. No mercado brasileiro, cada tonelada de lixo industrial perigoso, queimada por co-processamento, custa em média $\mathrm{R} \$ 300,00$ (trezentos reais). Observe a seguir a foto 2 (dois), em que podemos visualizar as imagens de fornos de cimento que utilizam a técnica do co-processamento.

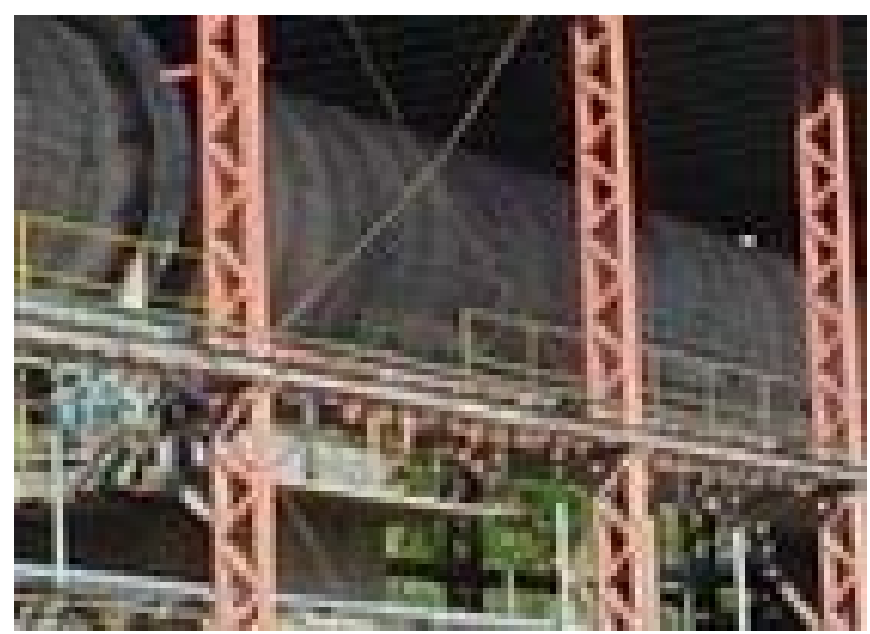

Foto 1: Forno de Cimento que utiliza co-processamento da empresa Resotec em Cantagalo, Rio de Janeiro.

Fonte : www.resotec.com.br

\footnotetext{
${ }^{71}$ PCBs ou bi-fenilos policlorados : possuem sua comercialização proibida no País desde 1981 , onde os estoques destes produtos encontram-se em poder dos geradores para incineração .
} 


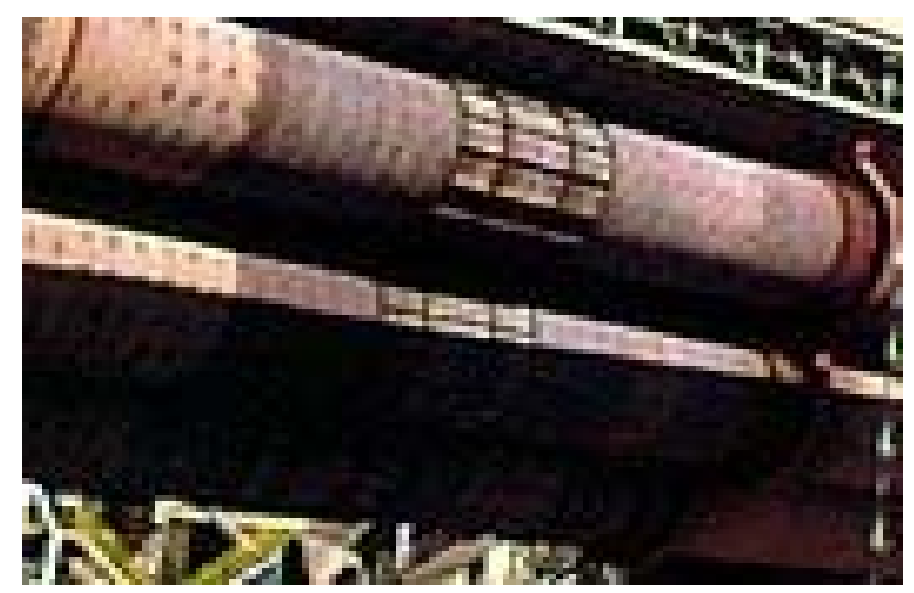

Foto 2: Forno de Cimento que utiliza co-processamento da empresa Resotec em Pedro Leopoldo, Minas Gerais.

Fonte : www.resotec.com.br

Além da incineração e o co-processamento, as empresas brasileiras utilizam o sistema de Bolsa de Resíduos para minimizar a destinação dos mesmos. Espalhadas pelo País, por intermédio das entidades representativas do setor empresarial, buscam promover a livre negociação entre as indústrias de resíduos. No entanto, os sistemas de representação industrial não são autorizados por lei a fiscalizarem o comércio de troca, compra ou venda dos resíduos destes bancos de dados. Desta forma, é necessário que haja uma certificação, ou mesmo, um estudo maior a fim de que se tenha a certeza de que esta movimentação de resíduos não acarretará problemas à saúde humana e impactos ambientais no território nacional ferindo gravemente a filosofia principal da Convenção de Basiléia.72

A Convenção de Basiléia sobre o Controle de Movimentos Transfronteiriços de Resíduos Perigosos e Disposição Final propõe, desta forma, ser um suporte para a busca do gerenciamento integrado dos resíduos perigosos no País. Despejos de siderurgia, da indústria química, pilhas usadas, acumuladores são elementos que causam ameaça à saúde humana e citada na Convenção como resíduos proibidos de exportação. O que realmente interessa é a manutenção da ordem econômica vigente e a manutenção e perpetuação dos recursos naturais para que estes durem o tempo

\footnotetext{
${ }^{72}$ Os sistemas mantidos pelas indústrias como a Federação Nacional das Indústrias do Estado de São Paulo (FIESP), ou ainda, a Federação Nacional das Indústrias do Estado do Rio de Janeiro (FIRJAN) são exemplos de manutenção de bancos de dados de Bolsa de Resíduos. Para acessar basta dirigir-se ao endereço eletrônico www.fiesp.org.br ou www.firjan.org.br
} 
necessário para a produção dos bens que a sociedade deseja. Neste sentido, buscamos através de operações de depósito, mencionadas no anexo IV da Convenção de Basiléia ou através da reciclagem, incineração e reutilização de materiais manter a ordem ecológica necessária. Neste contexto lembramos da citação de Leff quando menciona a ferramenta de escape que seria a reciclagem dos materiais:

Por um lado, o controle político-econômico sobre os diversos recursos, setores produtivos e mercados diminuem em alguns casos a compulsão para a superexploração da Natureza, ao mesmo tempo, em que ocorre um processo de mudança tecnológica, que procura reduzir os seus impactos ecológicos através de processos mais ecologicamente eficientes, com a indústria da reciclagem. ${ }^{73}$

3.1- Os inventários estaduais de resíduos sólidos industriais no Brasil

A consolidação dos inventários estaduais, realizados pelos órgãos estaduais de meio ambiente, (OEMAS) sobre as principais indústrias geradoras e processadoras de resíduos perigosos permite promover o monitoramento junto a essas indústrias. Tornando-se um ponto positivo para o País em três aspectos: o primeiro é no sentido de proporcionar impulso para a Convenção de Basiléia pelo envio de dados possibilitando que o País obtenha fundos de recursos para implantação de tecnologias limpas no País , o segundo é poder perceber e fiscalizar por conseqüência as principais unidades geradoras de rejeitos e o terceiro estabelecer políticas públicas de controle e prevenção.

Deste modo, as principais informações para o início da elaboração do Inventário Nacional de Resíduos Sólidos Industriais foram obtidas em pesquisas realizadas pelos técnicos do IBAMA e do Ministério do Meio Ambiente em alguns órgãos estaduais de meio ambiente (OEMAS), entendidas como órgãos estaduais de meio ambiente, selecionadas para busca de dados recentes sobre os inventários estaduais. As OEMAS visitadas foram a Companhia de Tecnologias de Saneamento Ambiental (CETESB-SP), a Fundação Estadual de Engenharia do Meio Ambiente (FEEMA-RJ), em razão do conhecimento acumulado ao longo dos anos, em particular quanto a realização de estudos, projetos de inventários de resíduos nacionais; Fundação Estadual de Proteção Ambiental (FEPAM-

\footnotetext{
${ }^{73}$ LEFF, H. Ecologia, Capital e Cultura. Blumenau: Furb. 2000. pg.280
} 
RS), cuja experiência foi adotada pelo Ministério do Meio Ambiente (MMA) para a definição da metodologia do Inventário Nacional de Resíduos e Companhia Pernambucana de Meio Ambiente (CPRH-PE), que havia concluído, recentemente, seu primeiro inventário de resíduos industriais; Instituto Ambiental do Paraná (IAP-PR) por ser o primeiro estado a concluir seus inventários no âmbito do projeto Ministério do Meio Ambiente através do Fundo Nacional do Meio Ambiente em parceria com o Instituto Brasileiro do Meio Ambiente e dos Recursos Naturais Renováveis (MMA/FNMA/IBAMA) para elaboração do inventário nacional.

A resolução CONAMA número 6 de dezesseis de junho de 1998, já determinava a realização de inventários estaduais. Mas, muito pouco foi feito neste sentido, restringindo-se a algumas iniciativas isoladas. Como conseqüência, não existem no País estatísticas nacionais sobre a geração, gerenciamento e disposição final dos resíduos industriais. De acordo com o estabelecido na resolução CONAMA 313 de 29.10.2002, que revogou a anterior (6/1998) e dispõe sobre o inventário nacional de resíduos, os estados têm o prazo de 02 (dois) anos, a partir da data de publicação da referida resolução, para apresentação dos dados de suas gerações junto ao IBAMA, gestor do inventário nacional. Os mesmos devem ser atualizados pelas OEMAS de dois em dois anos e no prazo de 03 (três) anos, ou seja, em 2005, os estados deverão contar com seus respectivos programas de gerenciamento de resíduos industriais e a união deverá apresentar um Plano Nacional de Gerenciamento de Resíduos Industriais em 2006. Observe a seguir dados de duas das OEMAS que possuíam seus inventários de geração de rejeitos.

\section{CETESB - Companhia de Tecnologias de Saneamento Ambiental (SP)}

Desde o início da década de 1980, a CETESB vem atuando sistematicamente na área de resíduos industriais. Em 1983 foi implantado o Programa de Controle da Poluição por Resíduos Industriais em Cubatão, sendo ampliado em 1986 para as regiões do Vale do Paraíba, Campinas e Sorocaba. Iniciaram-se, então, os levantamentos de resíduos industriais em todo o Estado e a partir da seleção de fontes prioritárias de geração de resíduos e o estabelecimento de procedimentos de controle específicos. Os dados, atualmente, disponíveis sobre a geração de resíduos industriais em São Paulo são os constantes no inventário de 1992/1993 e atualizado em 1996. Observe a tabela oito a seguir que demonstra os maiores geradores do Estado e que pertence a este inventário. 
Tabela 4 - Geração de Resíduos Industriais no Estado de São Paulo

\begin{tabular}{|l|c|l|c|}
\hline \multicolumn{1}{|c|}{ Indústria } & $\begin{array}{c}\text { Resíduos Classe } \mathbf{I}^{\mathbf{1}} \\
\text { (X 1000 ton./ano) }\end{array}$ & Indústria ${ }^{2}$ & $\begin{array}{c}\text { Resíduos Classe I } \\
\text { (X 1000 ton/ano) }\end{array}$ \\
\hline Química & 117.4 & Material Elétrico & 10.3 \\
\hline Material de Transporte & 116.8 & Mecânica & 5.5 \\
\hline Couro e peles & 76.3 & Produtos Alimentares & 3.3 \\
\hline Metalúrgica & 76.3 & Produtos Farmacêuticos & 3.2 \\
\hline Minerais e não Metálicos & 28.0 & Têxtil & 2.6 \\
\hline Papel e Papelão & 26.7 & Outros & 9.3 \\
\hline
\end{tabular}

Fonte: CETESB, Inventário de Resíduos Industriais, 1996.

A primeira consideração a ser observada resulta nas datas das bases de dados de 1996 totalizando quase dez anos da elaboração destes números. Para que tenhamos uma amostragem que demonstre a realidade da geração de resíduos sólidos industriais no Estado de São Paulo necessitamos de uma nova coleta de dados para avanços maiores no tocante ao envio de dados para a consolidação do Plano Nacional de Gerenciamento de Resíduos Industriais. A segunda consideração a ser feita é que tal mapeamento deve cobrir qualquer atividade industrial, pois todos os estabelecimentos de produção geram resíduos. Por fim, a terceira consideração pertinente é a busca no Estado de São Paulo diante dos dados apresentados nesta tabela de uma gestão efetiva no uso do transporte, pois esta categoria ocupa a segunda posição na tabela quanto à geração de rejeitos e que implica uma movimentação que possa trazer riscos à saúde do meio ambiente e da população local no trânsito de produtos.

\footnotetext{
${ }^{1}$ A classificação dos resíduos é regulamentada pela Associação Brasileira de Normas Técnicas (ABNT), através da NBR 10004 em que resíduos Classe I - Perigosos: Apresentam periculosidade ou uma das seguintes características: inflamabilidade, corrosividade, reatividade, toxicidade e patogenicidade. Ex: baterias, produtos químicos.

${ }^{2}$ A classificação dos resíduos é regulamentada pela Associação Brasileira de Normas Técnicas (ABNT), através da NBR 10004 em que resíduos Classe II - Não Inertes: Não se enquadram como resíduos classe I - Perigosos ou resíduos Classe III - Inertes e podem ter as seguintes propriedades: combustibilidade, biodegradabilidade ou solubilidade em água. Ex: matéria orgânica e papel.
} 
FEEMA - Fundação Estadual de Engenharia do Meio Ambiente (RJ)

Em 1996, a FEEMA desenvolveu o projeto de gerenciamento de resíduos industriais e elaborou 0 diagnóstico de 531 unidades industriais, todas localizadas na Baia de Guanabara. Foi estimada a geração mensal de 20.302.11 toneladas de resíduos industriais sendo 9.847 .68 ton./mês de resíduos de Classe I, 4.066.32 ton./mês de resíduos de Classe II e 6.388.10 ton./mês de Classe III. Observe a tabela nove a seguir demonstrando o fruto deste trabalho.

Tabela 5 - Geração de Resíduos Industriais na Bacia do Guanabara (RJ)

\begin{tabular}{|l|l|l|l|l|}
\hline \multicolumn{1}{|c|}{ Ano/Classe } & \multicolumn{1}{|c|}{ Classe I $^{1}$} & \multicolumn{1}{|c|}{ Classe II $^{2}$} & \multicolumn{1}{c|}{ Classe III ${ }^{3}$} & \multicolumn{1}{c|}{ Total } \\
\hline Dezembro /1999 & 9.951 .645 & 6.741 .07 & 26.630 .79 & 43.323 .51 \\
\hline Julho/ 2000 & 10.075 .16 & 3.860 .32 & 18.067 .51 & 32.002 .99 \\
\hline
\end{tabular}

Fonte: FEEMA - Programa de despoluição da baia de Guanabara, 2000.

A tabela nove já demonstra dados mais recentes que a tabela oito, denominada geração de resíduos industriais no Estado de São Paulo, no entanto, com características diferentes de demonstração dos resíduos. A tabela oito demonstra os resíduos e sua fonte de origem, enquanto a tabela nove demonstra por tipo de classe. Ora, devemos chegar a uma única forma de expressão dos dados, uma única metodologia para todos os estados brasileiros para que possamos efetivamente possibilitar a construção de um perfil nacional dos resíduos industriais, caso contrário, os esforços para a elaboração desta pesquisa serão maiores do que já são esperados.

\footnotetext{
${ }^{1}$ A classificação dos resíduos é regulamentada pela Associação Brasileira de Normas Técnicas (ABNT), através da NBR 10004 em que resíduos Classe I - Perigosos: Apresentam periculosidade ou uma das seguintes características: inflamabilidade, corrosividade, reatividade, toxicidade e uma das seguintes características: inflamabilidade, corrosividade, reatividade, toxicidade e patogenicidade. Ex: baterias, produtos químicos.

${ }^{2}$ A classificação dos resíduos é regulamentada pela Associação Brasileira de Normas Técnicas (ABNT), através da NBR 10004 em que resíduos Classe II - Não Inertes: Não se enquadram como resíduos Classe I - Perigosos ou resíduos Classe III - Inertes e podem ter as seguintes propriedades: combustibilidade, biodegradabilidade ou solubilidade em água. Ex: matéria orgânica e papel.

${ }^{3}$ A classificação dos resíduos é regulamentada pela Associação Brasileira de Normas Técnicas (ABNT), através da NBR 10004 em que resíduos Classe III - Inertes: Não têm constituinte algum solubilizado em concentração superior ao padrão de potabilidade de águas. Ex: rochas, tijolos, vidros e certos plásticos e borrachas que não são decompostos prontamente.
} 
Deste modo, os estados brasileiros mais do que nunca devem seguir as diretrizes do Ministério do Meio Ambiente e do IBAMA na coletagem e na organização dos dados de geração dos resíduos industriais. Somente assim poderemos concluir o inventário nacional.

\section{4- Plano de Desenvolvimento da Convenção da Basiléia no Brasil}

Um dos principais itens desenvolvidos nos anos de 2003/2004 foi o de estabelecer 0 início de programas de prevenção e minimização de resíduos perigosos e instrumentos, além de assistência no desenvolvimento da legislação nacional, políticas públicas, incluindo as bases legais, aperfeiçoar o uso de inventários bem como de auditorias.

Iniciativas propostas aos países:

Preparação de manuais com o resumo da legislação nacional para instrumentalizar sobre o assunto:

No caso do Brasil tal item ainda não foi desenvolvido. O País está engajado em organizar o seu inventário nacional de resíduos perigosos. Os inventários estaduais estão muito lentos e desalinhados metodologicamente. Não existe um critério entre eles para o enquadramento do tipo de resíduos. Haverá uma segunda chamada do Ministério do Meio Ambiente (MMA), com recursos para organização metodológica nos itens a serem considerados para elaboração do nacional (vide anexa). A resolução CONAMA número seis de dezesseis de junho de 1988, já determinava a realização de inventários estaduais. Mas, muito pouco foi feito neste sentido, restringindo-se a algumas iniciativas isoladas. Como conseqüência, não existem no País estatísticas nacionais sobre a geração, gerenciamento e disposição final dos resíduos industriais. De acordo com o estabelecido na resolução CONAMA 313 de vinte e nove de outubro de 2002, que revogou a anterior (6/1998) e dispõe sobre o inventário nacional de resíduos, os estados têm o prazo de 02 (dois) anos, a partir da data de publicação da referida resolução, para apresentação dos dados de suas gerações junto ao IBAMA, gestor do inventário nacional. Os mesmos devem ser atualizados pelas OEMAS de dois em dois anos e no prazo de 3 anos, ou seja, em 2005, os estados deverão contar com seus respectivos 
programas de gerenciamento de resíduos industriais e a união deverá apresentar um Plano Nacional de Gerenciamento de Resíduos Industriais em 2006.

Preparação e assistência no uso de kits sobre a legislação nacional, reforçando o uso de inventários, auditorias, prevenção e minimização da percepção do tráfico ilegal, e prevenção de resíduos:

De forma pontual, as auditorias ambientais, a conscientização para o uso racional dos recursos naturais é praticado no País. Os órgãos ambientais brasileiros assumem uma posição mais de controle e punitiva do que de prevenção e educação. Neste sentido de conscientização, atuação dos Centros Nacionais de Tecnologias Limpas (CNTLS) e Serviço de Apoio a Pequenos e Médios Empreendedores (SEBRAE) são para este propósito.

Identificação dos resíduos prioritários e buscar o gerenciamento ambiental dos mesmos: A partir da consolidação nacional do inventário de resíduos, o País poderá solicitar a gestão ambiental dos mesmos em escala nacional. No entanto, o setor industrial brasileiro, já utiliza técnicas sofisticadas para o gerenciamento de resíduos industriais mesmo com esta ausência de identificação.

Elaboração de guias para os resíduos prioritários:

A partir da consolidação nacional do inventário de resíduos, o País poderá solicitar a gestão ambiental dos mesmos com guias nacionais referentes ao assunto. Atualmente, as informações são analisadas e os guias são produzidos apenas para certos setores industriais. Temos, por exemplo, 0 couro, a borracha entre outros. Esta situação ocorre, pois apenas estes setores receberam maiores restrições ambientais para produzirem seu produto, seja por parte das OEMAS ou por parte de outras entidades, ou ainda para atender fins de comércio de importação e exportação. No Guia de Importação Brasileira devem embutir as exigências do Estado assinado na Convenção. As empresas privadas devem passar pelo crivo do Estado e atender às normas internacionais assinadas pelo Estado e às normas e leis nacionais. 
Preparação de um manual com as indicações técnicas da Convenção para os setores industriais relevantes:

Não existe ainda um manual para o setor industrial brasileiro a respeito da Convenção e suas intenções. No entanto, nos Centros Nacionais de Tecnologias Limpas e no Sebrae (discutidos no capítulo III) o setor industrial encontra indicações técnicas da Convenção.

Estabelecer o uso do guia da Conferência das Partes com o propósito de identificar dificuldades de aplicação da Convenção:

Foi solicitado ao Brasil e a todos os países coniventes com a Convenção, através da comunicação do secretariado em vinte e dois de março de 2005, a transmissão de informações do ano 2003 sobre este item.

Desenvolvimento de projetos apontando melhorias, reciclagem e recuperação de resíduos perigosos, ou plantas de operação de reciclagem e recuperação. Preparação de manuais e treinamento para classificação e caracterização dos resíduos:

O Brasil não foi contemplado nos programas regionais existentes. Atualmente está em implantação o Programa Regional para Sul do Pacífico, onde as Ilhas Cook, Estados da Micronésia, Fidji, Kiribati entre outros estão providos de recursos para a criação de um sistema de controle de movimento dos resíduos perigosos. Além deste programa regional, existe o Programa Regional Relativo as Reservas da África, onde o objetivo é a eliminação de reservas de pesticidas na Etiópia, Mali, Marrocos, Nigéria, África do Sul, Tunísia e Tanzânia.

Preparação de especialistas para detalhar inventários e realizar auditorias ambientais: No que concerne à preparação de especialistas estes devem instruir os trabalhadores para os riscos químicos, possibilitando a segurança no trabalho. Busca-se a harmonia da etiquetagem dos produtos, troca de informações entre os países e facilitar o entendimento pelo consumidor, havendo assim a otimização das capacidades dos trabalhadores para leitura da periculosidade do material. 
Identificação de instrumentos financiadores para auxiliar os Estados no desenvolvimento:

Através de recursos advindos do Banco Mundial e do Fundo Ambiental Mundial pertencente ao Fundo Monetário Internacional, a África e o Sudoeste do Pacífico foram as áreas selecionadas para recebimento de divisas. Recebem também suporte quanto à produção mais limpa por intermédio da United Nations Environment Programme_(UNEP).

\section{1- Plano Estratégico para a Implementação da Convenção da Basiléia no Brasil - 2005/2010}

Durante o período de 2000 a 2010, os grupos de trabalho da Convenção pretendem construir uma estrutura enfatizando a ampla implementação nos Estados-Partes do tratado, com esforços de seus comitês nacionais. Baseado na Declaração Ambientalmente Saudável dos Resíduos Perigosos e Outros Resíduos, este documento fora elaborado para facilitar a internalização da Convenção nos países integrantes. O plano e suas questões foram construídos a partir do encontro do Ministério da Convenção em 1999 no tema gerenciamento ambiental, que identifica e descreve as atividades consideradas apropriadas para os países com o respeito e interesse de todos os atores envolvidos, considerando os dez anos de implantação. O plano contempla metas regionais, programas, estratégias, permitindo sustentabilidade aos mesmos e até ações em busca do desenvolvimento sustentável. Este plano é composto de um texto estratégico e atividades de longo prazo para 2005/2010.

A outra área de foco será a minimização da geração de resíduos perigosos. Considerando ser uma alternativa de longo prazo, a redução de resíduos na geração será perseguida, perdendo espaço, portanto, a preocupação da movimentação transfronteiriça, atitude posterior à geração. Observe a seguir a introdução da Declaração Ambiental da Convenção priorizando este objetivo.

O amplo gerenciamento dos resíduos perigosos e demais são mencionados na Declaração Ambiental da Convenção e este gerenciamento requer ações em todos os níveis da sociedade: treinamento, informação, comunicação, instrumentos metodológicos, capacidade de infraestrutura com suporte financeiro, transferência de recursos humanos, conhecimento e manuseio 
de tecnologias limpas, são itens que concretizam a implementação da Declaração da Convenção. (Introdução)

O efetivo envolvimento e coordenação de todos os atores são essenciais para o alcance do conhecimento da Convenção, bem como os objetivos da Declaração da Basiléia. As partes devem levar em consideração o princípio da responsabilidade comum, mas diferenciada. Governos devem estimular programas e atividades, e buscar auxilio do secretariado e centros regionais (BCRCS) da Convenção e de todos os agentes envolvidos no gerenciamento dos resíduos. Os centros regionais são os parceiros na implementação da Convenção nos níveis regionais. As mobilizações da indústria e de organizações não governamentais são importantes para avaliar as aplicações práticas do gerenciamento ambiental. As partes são responsáveis por estabelecer, manter e aperfeiçoar, quando necessário, a estrutura política requerida para avaliação e monitoramento do progresso do plano estratégico. 0 aprimoramento da troca de informações, bem como o crescimento e educação em todos os setores da sociedade é um parâmetro importante para o alcance dos objetivos da Convenção. Desta forma para garantir que os individuos conheçam a Convenção e busquem a gestão dos resíduos industriais, as estratégias do secretariado e dos Estados-Partes são:

Envolver especialistas em promover os objetivos da Convenção, no tocante ao gerenciamento ambiental e para a ratificação da mesma, bem como suas emendas, com ênfase nas atividades propostas em curto prazo:

Neste item o ponto focal do Brasil (IBAMA e MMA) buscará as melhores alternativas para o gerenciamento ambiental e para a consolidação da ratificação do tratado no País. As atividades propostas a curto prazo para o Brasil.

Engajar e estimular os grupos interessados nas partes a acompanhar o secretariado e explorar o crescimento de estratégias para a preparação de projetos usando os especialistas de organizações não públicas:

No que diz respeito aos resíduos industriais no Brasil, especialistas de organizações não públicas tem muito a contribuir, pois as empresas contratam os mesmos para o alcance da gestão de seus resíduos. 
Motivar parcerias para trocar valores e estimular o progresso em curto prazo:

As parcerias em curto prazo entre Estados-Partes já ocorrem, mas 0 Brasil ainda não está contemplado. 0 que esperamos é que os programas internacionais também invistam no Brasil recursos para estimular valores e progresso na gestão de resíduos em longo prazo.

Disseminar a informação da maneira mais fácil possivel pela Internet e outros meios eletrônicos e também pelos centros regionais:

A página eletrônica da Convenção oferece um amplo acesso a todas as informações sobre o tema, tanto no Brasil como nos demais Estados-Partes. Nos endereços eletrônicos do Centro Nacional de Tecnologias Limpas, Serviço Brasileiro de Apoio as Empresas (SEBRAE) e no Ministério do Meio Ambiente (MMA) encontramos informações nacionais articuladas com o tratado. No entanto, é necessário que outros órgãos também divulguem informações como, por exemplo, as federações de indústrias e os órgãos ambientais estaduais e municipais, dando ênfase na utilização de uma linguagem acessivel a toda sociedade.

Revisar periodicamente atividades em relação aos indicadores da Declaração: Neste sentido, o Brasil realiza o primeiro passo, a articulação do inventário nacional de resíduos industriais, um dos resíduos que contém a característica de periculosidade. O Brasil já possui a Pesquisa Nacional de Saneamento Básico que reúne estatísticas sobre os resíduos sólidos urbanos e rurais. 0 grande desafio será a atualização destes dados pelos órgãos públicos para permitir que os indicadores da Convenção sejam também atualizados.

Colaborar com as instituições e programas existentes à promoção do uso de tecnologias limpas, transferência tecnológica, metodologias, instrumentos econômicos ou políticas para facilitar a construção da capacidade tecnológica, para assim concretizar o gerenciamento dos resíduos perigosos:

O Centro Nacional de Tecnologias Limpas no Brasil é a primeira instituição a realizar este item. A intenção é que os órgãos de fiscalização e controle ambiental dos estados brasileiros também 
promovam e colaborem para a promoção de tecnologias limpas, bem como outras entidades (federação de indústrias, ongs, etc.).

\section{5- Os Centros Nacionais de Tecnologias Limpas no Brasil}

Os Centros Nacionais de Produção Mais Limpa ${ }^{74}$ (National Centers of Clean Production - NCPC) originados de uma iniciativa entre a Organização das Nações Unidas para o Desenvolvimento Industrial (United Nations Industrial Development Organization - UNIDO), Programa das Nações Unidas para o Meio Ambiente (United Nations Environment Programme - PNUMA) e o Centro de Atividades do Programa de Meio Ambiente de Paris visam estabelecer uma rede formada por instituições e profissionais com o objetivo de transferência de informação e tecnologia para as empresas permitindo a incorporação de técnicas de produção mais limpa em seus sistemas de gerenciamento ambiental. Atualmente conta com vinte e um centros instalados no Mundo, sendo que um deles pertence ao Brasil, que ingressou no programa em 1995. Os demais centros estão no: México, Costa Rica, Nicarágua, El Salvador, Guatemala, República Tcheca, Moçambique, Zimbábue, Tanzânia, Kenya, Etiópia, Marrocos, Tunísia, Índia, Eslováquia, Hungria, China, Vietnã, Rússia, Croácia.

O treinamento de pessoal e a transferência de tecnologias para o Brasil, fundamentais na implementação da Convenção de Basiléia, deverão ser realizados no Centro de Treinamento e Transferência de Tecnologias. O Serviço Nacional de Aprendizagem Industrial (SENAI) é o órgão executor do projeto de cooperação técnica para o estabelecimento dos Centros Nacionais de Produção mais Limpa que visam disseminar tecnologia limpa no Brasil. A rede de tecnologias limpas estende-se pelo Brasil, no presente momento, através do intercâmbio com o Serviço de Apoio a Pequenos e Médios Empreendedores (SEBRAE). 75

\footnotetext{
${ }^{74} \mathrm{O}$ Centro Nacional de Tecnologias Limpas (CNTL) são mencionados dentro da Agenda 21 em seu capítulo vinte, quando se refere à Convenção de Basiléia como um apoio para manejo saudável dos resíduos perigosos.

${ }^{75}$ Entendemos por produção mais limpa a aplicação de uma estratégia econômica, ambiental e técnica, integrada aos processos e produtos, a fim de aumentar a eficiência no uso de matérias - primas, água e energia, através da redução, reutilização ou reciclagem de resíduos gerados com benefícios ambientais e econômicos para a produção.
} 
A redução, geração de resíduos perigosos e aplicação da produção limpa é a última meta da Convenção de Basiléia. A busca da redução da produção de resíduos perigosos é estimulada pela Convenção através de seu artigo quatro parágrafo dois:

Assegurar que a geração de resíduos perigosos e outros resíduos em seu território sejam reduzidos a um mínimo, levando em consideração aspectos sociais, tecnológicos e econômicos.

No artigo treze, a Convenção obriga as partes a transferirem anualmente informações e medidas que sejam entendidas como de desenvolvimento de tecnologias de redução e eliminação de resíduos perigosos.

Informações sobre medidas tomadas para desenvolver tecnologias destinadas a reduzir e/ou eliminar a produção de resíduos perigosos e outros resíduos.

O Secretariado da Convenção (SBC) tende a busca do uso da produção limpa em vez de utilizar técnicas convencionais do gerenciamento integrado dos resíduos. Em resumo, reduzir a geração dos resíduos perigosos e buscar a aplicação da tecnologia limpa é o objetivo principal da Convenção de Basiléia, mas é improvável alcançá-la a médio e longo prazo. Sendo assim, ela consegue prevenir os riscos a saúde humana e ambiental. Para esta meta, encontramos em seu preâmbulo mais uma vez esta afirmação. Observe:

Conscientes da necessidade de continuar o desenvolvimento e a implementação de tecnologias ambientalmente racionais, que gerem escassos resíduos, medidas de reciclagem e bons sistemas de administração e manejo, permitam reduzir ao mínimo a geração de resíduos perigosos e outros resíduos (Preâmbulo da Convenção).

Ou ainda:

Reconhecendo que é preciso promover a transferência de tecnologia para a administração saudável dos resíduos perigosos... (Preâmbulo da Convenção). 
Diante desta tendência do secretariado da Convenção pela preferência de tecnologias limpas, a diretoria de licenciamento e meio ambiente do Instituto Brasileiro do Meio Ambiente e dos Recursos Naturais Renováveis do Brasil, Ministério das Relações Exteriores brasileiro e os Centros de Tecnologias Limpas realizam intercâmbio de informações com o Secretariado da Convenção na busca de promover o uso e transferência de tecnologias no País.

Para difusão de tecnologias limpas o CNTL/SENAI atuam fundamentalmente na disseminação da informação, implementação de programas de produção mais limpa nos setores produtivos, capacitação de profissionais e na atuação em políticas ambientais. Quanto à disseminação da informação os Centros Nacionais de Produção mais Limpa constituem um elo chave, pois facilitam a distintos países, no idioma da localidade, o acesso a toda informação que se dispõe no mundo sobre produção mais limpa.

Os centros oferecem acesso imediato à documentação técnica, bases de dados e outras fontes de informação, prestam serviços de assessoramento às organizações sobre medidas adequadas para a implementação de práticas de Produção mais Limpa, divulgam informações através de seminários, boletins técnicos, folhetos e através da cooperação com os meios de informação nacional, associações de indústrias, institutos de capacitação e universidades.

Os Centros Nacionais de Produção mais Limpa, em cooperação com os funcionários das empresas, realizam avaliações dentro das mesmas, com o objetivo de utilizar a Produção mais Limpa para identificar processos que originem resíduos e recomendar soluções rentáveis. As empresas, com 0 apoio dos centros, aplicam as medidas de Produção mais Limpa especialmente destinadas a elas. A introdução de medidas economicamente satisfatórias de Produção mais Limpa, junto com a divulgação de informações sobre tecnologias alternativas, constitui a atividade central dos centros. Estas avaliações nas empresas mostram que a aplicação de medidas de prevenção da poluição e de uso racional dos recursos reduzem os impactos ambientais obtendo-se, simultaneamente, benefícios econômicos. 
Sendo assim, através dos cursos práticos de capacitação, os centros divulgam instrumentos e métodos para melhorar de forma contínua o processo. Consultores e institutos nacionais estão capacitados para proporcionar o apoio e o respaldo para empresas comprometidas em implementar produção mais limpa, além de fomentar o efeito multiplicador, à medida que o conceito começa a interessar novas companhias. Os centros também organizam programas de capacitação e cursos práticos sobre produção mais limpa para entidades governamentais, universidades, organizações comerciais e instituições financeiras.

A proliferação de tecnologias limpas no Brasil leva ao surgimento de novos caminhos como, por exemplo, à busca das empresas as certificações ambientais obtidas a partir da International Organization for Standardization (ISO) criada em 1947 tendo como objetivo normalizar acordos técnicos industriais globais. A série de normas ISO 14040 abrange esse importante aspecto de produção.

Outro caminho fruto do uso desta tecnologia é a busca da análise do ciclo de vida das matériasprimas industriais. A análise do ciclo de vida (Life Cycle Assessment ou LCA) é muito mais abrangente do que um estudo de balanço de energia e massa dos insumos. $A$ análise do ciclo de vida de um produto ou serviço compatibiliza os impactos ambientais decorrentes de todas as etapas envolvidas: desde sua concepção mercadológica, planejamento, extração e uso de matérias-primas, gasto de energia, transformação industrial, transporte, consumo até seu destino final - disposição em aterro sanitário, reciclagem, compostagem ou incineração. Desta forma, o acompanhamento da vida de um produto é feito de seu "berço ao túmulo". Note-se que, nessa avaliação, são considerados também os impactos indiretos.

Partindo destes novos caminhos da produção limpa, esperamos que, em um futuro próximo, cada vez menos sejam freqüentes episódios envolvendo a gestão ineficiente de resíduos perigosos como, por exemplo, caminhões em Santa Catarina, Sul do Brasil transportando carga tóxica com alimentos, resíduos das empresas Cica, Carbocloro Oxypar, Petrobrás, Texaco, Vale do Rio Doce, Shell do Brasil, Pepsi-Cola do Brasil, Phililps da Amazônia entre outras. ${ }^{76}$

\footnotetext{
${ }^{76}$ Fonte: Saneamento Básico. www.saneamentobasico.com.br de 4/08/2002.
} 
Somado ao uso de tecnologias limpas, devemos relembrar que o plano de atividades da Convenção de Basiléia demonstrado neste capítulo, tal como, a compilação e a elaboração de um inventário nacional de resíduos industriais, os avanços dos trabalhos da Coordenadoria da Segurança Química e, por fim, a aplicabilidade da legislação de resíduos industriais vigentes são nossas ferramentas, na presente data, para a busca de uma gestão dos rejeitos industriais.

No entanto, todas as ações mencionadas no parágrafo anterior além do uso de tecnologias limpas, representadas aqui pelos centros nacionais de produção mais limpa, representam medidas de tentar reequilibrar a equação de recursos naturais e de resíduos, buscando o que chamamos de desenvolvimento sustentável. $\mathrm{O}$ uso da tecnologia para reestruturar uma ordem de exploração de recursos naturais presente na sociedade em que vivemos é muito comum. Obviamente este mecanismo é utilizado para manutenção da atual vontade que o homem possui de dominar o que chamamos de Natureza e que contém os recursos naturais do qual tanto precisamos para manter os padrões culturais. Reforçamos que estas medidas são positivas e devem ser aplicadas, mas não são as soluções definitivas tão esperadas.

Deste modo, no capítulo quatro, denominado Aplicação da Convenção de Basiléia no Brasil, mostraremos ao leitor os itens necessários para a realização da movimentação transfronteiriça através de dois casos de movimentação que seguiram todos os requisitos legais nacionais e internacionais apropriados, bem como a preocupação com as condições de segurança no transporte e reuso dos resíduos. Os dois casos serão os de resíduos de cobre e resíduos de zinco que em todas as suas etapas de geração, movimentação, chegada em território brasileiro e uso deste como matéria-prima em território brasileiro cumpriram as exigências dos órgãos ambientais competentes, tal como os dizeres da Convenção de Basiléia. Mas, assim como as soluções científicas, as soluções legais não são as definitivas. 


\section{CAPÍTULO IV - APLICAÇÃO DA CONVENÇÃO DE BASILÉIA NO BRASIL}

O capítulo 4, denominado Aplicação da Convenção de Basiléia no Brasil, relataremos, logo de início, o procedimento de dois materiais selecionados para análise neste trabalho, que são os resíduos com os quais conseguimos comprovar as informações de movimentação transfronteiriça envolvendo o território brasileiro. Desta forma, avançaremos pelo universo da química, informando as propriedades do zinco, suas principais aplicações na sociedade contemporânea e os impactos à saúde humana e ao meio ambiente decorrentes de seu uso em coligação com outros elementos químicos. Faremos também o mesmo procedimento com o cobre, em que informaremos as suas propriedades e demais aplicações, idem ao zinco citado anteriormente.

O tema central de nosso capítulo é demonstrar ao leitor os itens necessários para a realização da movimentação transfronteiriça entre o Brasil e outro Estado - Parte da Convenção através de dois casos de movimentação que seguiram os requisitos legais nacionais e internacionais apropriados, bem como a preocupação com as condições de segurança no transporte e reuso dos resíduos. Os dois casos demonstrados serão os resíduos de cobre e resíduos de zinco, que em todas as suas etapas de geração, movimentação, chegada em território brasileiro e uso deste como matéria-prima em território brasileiro cumpriram as exigências dos órgãos ambientais competente, tal como os dizeres da Convenção de Basiléia. Deste modo, convidamos ao leitor para responder a seguinte questão: Quais são os itens necessários no Brasil para a realização da movimentação transfronteiriça de resíduos?

\section{1- Materiais controlados pela convenção no Brasil.}

1.1 - O Zinco

Enquanto mineral, o zinco encontra-se na crosta terrestre, associado a outros metais como o cobre e o chumbo. Os depósitos de zinco estão dispersos por todo o mundo, sendo muito vulgar encontrar massivos depósitos de zinco com bastante ferro misturado. As principais regiões onde ocorre a mineração de zinco são: o Canadá (19\%), ex-URSS (13,5\%), Austrália (11\%), China e Peru (7\%) e 
Espanha, México e EUA (4\% cada) ${ }^{77}$. Quando a o Planeta Terra se formou, o zinco se depositou na forma de sulfetos. O ZnS (sulfato de zinco) é extraído como minério, sendo chamado de "esfarelita" nos Estados Unidos e de "blenda" na Europa. A concentração por flotação do ZnS permite a extração do óxido de zinco (ZnO) e, por fim, de zinco (Zn).

O zinco metálico é usado na produção de ligas ou na galvanização de estruturas de aço. Este processo consiste na eletrodeposição de uma fina película de zinco sobre as peças a proteger, ou seja, utiliza-se a galvanização para proteger estruturas de edifícios ou partes constituintes de automóveis e barcos. 0 zinco também pode ser um aditivo de certas borrachas e tintas. Sem esquecer de comentar que uma das ligas mais importantes do zinco é o bronze, que consiste na mistura deste elemento com o cobre. 0 bronze é mais dúctil do que o cobre e tem uma resistência à corrosão bastante superior. O zinco pode ainda utilizar-se como eletrodos nas "vulgares" pilhas secas.

Os principais compostos de zinco são: o óxido ( $\mathrm{ZnO})$, utilizado nas indústrias de cerâmica e de borrachas e, ainda, na fabricação de tintas; o sulfato de zinco $\left(\mathrm{ZnSO}_{4}\right)$, que tem aplicação na indústria têxtil e no enriquecimento de solos pobres em zinco, sendo utilizados em painéis luminosos, telas de cinescópio e lâmpadas fluorescentes; e o cloreto de zinco que é usado para preservar madeiras, bem como desodorizante em diversos fluidos, sendo também utilizado em pilhas secas e como mordente em tintas.

O zinco desempenha um papel vital no desenvolvimento animal, pois acelera a absorção de monóxido de carbono $\left(\mathrm{CO}_{2}\right)$ pelas células vermelhas do sangue, em músculos e outros tecidos, acelerando também a reação inversa, que envolve a liberação de $\mathrm{CO}_{2}$ pelos pulmões. $\mathrm{O}$ zinco pode ser encontrado na água potável, em alguns alimentos (como carne vermelha) e, também, em alimentos provenientes do mar, tais como: ostras e conchas. Uma dieta rica em zinco diminui o risco de hemorragias e melhora a cicatrização das feridas. Na agricultura, o zinco é usado como suplemento nutritivo para promover o crescimento das plantas.

\footnotetext{
${ }^{77}$ Universidade Federal do Rio de Janeiro. http://www.if.ufri.br/teaching/elem/e02940.html Acesso em dezesseis de junho de 2005.
} 
É estranho saber que o zinco é um elemento essencial à vida, enquanto os outros dois elementos deste grupo, o Cd (cádmio) e o $\mathrm{Hg}$ (mercúrio), são extremamente tóxicos. 0 maior risco de intoxicação com cádmio ocorre na fundição do zinco, pois o $\mathrm{Cd}$ pode escapar como poeira junto com os gases liberados. A fabricação de baterias Níquel e Cádmio (Ni/Cd) tem causado problemas neste sentido. Quando ingerido o $\mathrm{Cd}$ acumula-se nos rins, provocando seu mau funcionamento e impedindo a atuação de certas enzimas importantes para a atividade deste órgão. 0 vapor de mercúrio é tóxico, e se inalado pode provocar vertigens, tremores, danos aos pulmões e cerebrais. 0 mercúrio é um veneno cumulativo e como não existe um mecanismo para sua eliminação no organismo humano torna-se extremamente perigoso. Esse elemento foi empregado para controlar 0 crescimento de bolores em fábricas de polpa de celulose e de papel. São ainda usados em tintas protetoras contra o apodrecimento e como fungicidas no tratamento de sementes e de plantas. Os altos índices de mercúrio em seres humanos podem causar paralisias, perdas de visão, surdez, loucura e até a morte. Como no caso de Minamata, mencionado no capítulo dois deste trabalho, onde a população ingeriu peixe contaminado por mercúrio e que acarretou graves conseqüencias.

A reciclagem do zinco já é realidade e, um exemplo desta, consiste na separação dos componentes de pilhas, e como elas são multicomponentes, suas desmontagens são complexas e o processo de reciclagem consome grande quantidade de energia.

As pilhas são objetos pequenos, comuns e de grande comercialização. Tóxicas, são comumente despejadas no lixo doméstico e encaminhadas para aterros sanitários, onde, a céu aberto, entram em decomposição e liberam metais pesados no solo. Com o tempo, a acumulação destes elementos poderá provocar danos irreversíveis ao meio ambiente, ou seja, na fauna, flora e até na cadeia alimentar.

As pilhas de uso comum, do tipo zinco associado ao manganês, ambos metais pesados, podem ser recuperadas. 0 desmonte manual permite separar os componentes básicos das pilhas: 0 invólucro externo (papelão e plástico), a blindagem de aço e o copo de zinco. 0 próximo passo é o tratamento da pasta eletrolítica juntamente com o zinco, a partir da fusão com NAOH (hidróxido de sódio), seguida de dissolução em água.

São resultantes desse processo uma solução verde-escura de manganato e zincato de sódio, dióxido de manganês e óxido de zinco (ambos de interesse econômico), além de um resíduo líquido 
final salino incolor (sulfato de sódio) e um resíduo sólido insolúvel contendo mercúrio, ferro, níquel e chumbo. Isso mostra que, embora o manganês e o zinco sejam os metais ativos no funcionamento das pilhas, existem outros metais pesados que podem ser encontrados em pequenas quantidades, 0 que reforça a necessidade de reciclagem das pilhas. A resolução do Conselho Nacional do Meio Ambiente (CONAMA) número 257, de trinta de junho de 1999, estabelece níveis máximos de mercúrio, cádmio e chumbo nas pilhas, que podem assim ser descartadas em aterros sanitários comuns. 78

\section{2- 0 cobre}

O cobre está bastante distribuído por todo o planeta Terra, sendo particularmente comum encontrálo combinado com ferro, carbono e oxigênio. Atualmente, são conhecidas mais de uma centena de minerais de cobre. No entanto, apenas seis têm interesse comercial. Os principais produtores do cobre são: o Chile (17\%), Estados Unidos (16\%), a ex-URSS (11\%), Canadá (8\%), Zâmbia (5,5\%), Zaire e Polônia $(5 \% \text { cada })^{79}$. Esse metal é usado na indústria elétrica por causa da sua elevada condutividade. Também é usado em tubulações de água, devido a sua inércia química. A atual indústria de cobre depara com numerosos problemas, pelo fato de este elemento ser tecnologicamente superado por outros materiais como o alumínio, o aço ou os plásticos.

Os minerais de cobre podem dividir-se em três grupos distintos. Os minerais primários, que estão depositados a grande profundidade e têm origem ígnea, como por exemplo a bornite $\left(\mathrm{Cu}_{5} \mathrm{FeS}_{4}\right)$, calcopirita $\left(\mathrm{CuFeS}_{2}\right)$, enargite $\left(\mathrm{Cu}_{3} \mathrm{As}_{5} \mathrm{~S}_{4}\right)$ e outros. $\mathrm{O}$ segundo grupo é composto por minerais de cobre oxidado resultantes da erosão de sulfuretos de cobre. Neste grupo, destacam-se os minerais cuprite $\left(\mathrm{Cu}_{2} \mathrm{O}\right)$, malaquite $\left(\mathrm{CuCO}_{3} \cdot \mathrm{Cu}(\mathrm{OH})_{2}\right)$, azurite $\left(2 \mathrm{CuCO}_{3} \cdot \mathrm{Cu}(\mathrm{OH})_{2}\right)$ e crisocola $\left(\mathrm{CuSiO}_{3} \cdot 2 \mathrm{H}_{2} \mathrm{O}\right)$. E o terceiro grupo é constituído por minerais resultantes da erosão de sulfuretos de cobre, tais como: a calcocite $\left(\mathrm{Cu}_{2} \mathrm{~S}\right)$ e a covelite (CuS).

Os minerais com maior interesse comercial são a calcocite $\left(\mathrm{Cu}_{2} \mathrm{~S}\right)$, que possui $79,8 \%$ de cobre e a calcopirite $\left(\mathrm{CuFeS}_{2}\right)$ com 34,5\%. Minerais como enargite ou outros sulfuretos podem viabilizar a

\footnotetext{
${ }^{78}$ Revista Ciência Hoje on-line, Reciclagem de Pilhas. www.uol.com.br/cienciahoje de treze de outubro de 2003, Textos e fotos Julio Lobato. Acesso em treze de julho de 2005.

${ }^{79}$ Universidade Federal do Rio de Janeiro. http://www.if.ufri.br/teaching/elem/e02940.html. Acesso em dezesseis de junho de 2005.
} 
exploração que usualmente se faz em mina aberta. A minagem em profundidade é menos comum, na extração de cobre, devido aos seus elevados encargos.

Os compostos cuprosos $(\mathrm{Cu}+)$ e cúpricos $(\mathrm{Cu}++)$ são muito diversos, apresentando um vasto leque de aplicações. O cloreto cuproso é usado extensivamente como: catalisador, agente dessulfurizante e, ainda, como branqueador na indústria petrolífera. Usa-se o cloreto cúprico como mordente na tinturaria têxtil e como agente oxidante em corantes. Sendo utilizado, também, como fungicida. 0 óxido cuproso é usado na pintura de cascos de navios, de madeira ou aço, para proteger da ação desgastante da água do mar. O nitrato cúprico é usado para sensibilizar superfícies à luz, enquanto o fluoreto se utiliza como opacificador em esmaltes, vidros e cerâmicas. O sulfato de cobre é usado como fungicida, inseticida e como aditivo do solo, para evitar que as deficiências de cobre afetem as colheitas.

O uso comercial do cobre puro se refere a aplicações mais delicadas, tais como: a produção de fios destinados a aplicações elétricas. É essencial que a pureza seja mantida para garantir a alta condutividade e a capacidade de recozimento consistente e para que não haja quebras durante a produção do vergalhão e na manufatura do fio. 0 cobre primário de melhor qualidade é utilizado na produção do vergalhão para essa finalidade.

Além do uso na eletricidade, o cobre também é utilizado para fabricar tubos, chapas para cobertura de telhados e trocadores de calor, entre outras aplicações. Nesses casos, é desnecessário seu alto grau de condutibilidade elétrica, e seus outros requisitos de qualidade não são tão onerosos. 0 cobre secundário pode ser utilizado na produção desses materiais, embora dentro de um limite estipulado para impurezas.

A atividade do cobre no metabolismo vegetal manifesta-se de duas formas: na síntese da clorofila e na atividade de algumas enzimas. Embora não exista na clorofila, o cobre é indispensável em sua produção. A sua falta provoca deficiências fotossintéticas e incapacidade de produção de sementes. O cobre é também constituinte de muitas enzimas responsáveis pela catálise de reações de oxidação-redução.

Este elemento desempenha igualmente um papel importante no metabolismo animal. Um homem adulto necessita de $2 \mathrm{mg}$ de cobre por dia, contendo seu corpo cerca de 100 a $150 \mathrm{mg}$ do 
elemento ${ }^{80}$. A falta de cobre na dieta animal pode provocar anemia, diarréia e distúrbios nervosos. Por outro lado, a ingestão excessiva de compostos como o sulfato de cobre pode causar vômitos, cãibras, convulsões ou, mesmo, a morte. Algumas intoxicações são relatadas. Como, por exemplo, o relato de agricultores de Portugal que utilizavam em seu vinho misturas à base de cobre, ditas misturas de Bordeaux, pelo qual foi notado que sua síndrome se associou a febre, diminuição de apetite, fraqueza muscular e patologia pulmonar, o que pode levar a câncer no pulmão e a cirrose do fígado. Nos Estados Unidos, um regime contendo certos legumes e fígado de boi parece ser suficiente para inibir as deficiências da ausência do cobre.

A sucata de cobre pode ser reciclada pela simples fusão e inspeção antes da fundição, seja para 0 formato final ou para fabricação posterior. Entretanto, esse processo só é válido para sucatas obtidas em ambientes de manuseio exclusivo de cobre. Quando o cobre se contaminar e for necessário um novo refino, normalmente será necessário derretê-lo e fundi-lo no formato de ânodo para que seja purificado por eletrólise ${ }^{81}$.

No entanto, se o nível de impurezas no ânodo for significativo, é pouco provável que o cátodo produzido vá atender aos altos padrões exigidos para o cobre 'A', utilizado na fabricação de fios e cabos elétricos.

O latão, ligação entre o zinco e o cobre, é uma liga utilizada em moedas, medalhas, bijuterias, radiadores de automóvel, ferragens, cartuchos, diversos componentes estampados e conformados, entre outras aplicações.

A reciclagem da sucata de latão é essencial para a indústria. O latão para extrusão e estampagem à quente é normalmente obtido a partir da fusão de sucata com composição similar e corrigido pela adição de cobre virgem ou zinco, conforme o caso, para atender às especificações antes de vertê-lo.

A presença de outros materiais no latão, como o chumbo, é freqüentemente necessária para melhorar a sua usinagem, de forma que esses elementos são aceitáveis.

A sucata de latão, originada nas operações de usinagem, pode ser fundida economicamente, mas deve ser isenta de excesso de lubrificantes, especialmente daqueles que contêm compostos

\footnotetext{
${ }^{80} \mathrm{http://www.oligopharma.com.br/oligoelementos/cobre.htm} \mathrm{acesso} \mathrm{em} \mathrm{13.10.2005.}$

${ }_{81}$ A eletrólise é um processo que separa os elementos químicos de um composto através do uso da eletricidade. De maneira sumária, procede-se primeiro a decomposição ( ionização ou dissociação ) do composto em íons e, posteriormente, com a passagem de uma corrente contínua através destes íons são obtidos os elementos químicos. In: Wikipédia, a enciclopédia livre, acesso em treze de julho de 2005.
} 
orgânicos que causam fumaça, inaceitável durante o processo de fusão. Quando o latão é fundido de novo, há a evaporação do zinco mais volátil. Isso é compensado no líquido para corrigir a especificação.

O latão que será manufaturado no formato de chapas e tiras deve ser consideravelmente livre de impurezas a fim de manter a ductibilidade quando resfriado. Ele pode ser enrolado, repuxado, estampado, rebitado ou sofrer qualquer outra forma de moldagem a frio. É normal fabricá-lo a partir do cobre virgem ou zinco, preponderantemente, em conjunto com sucata processada a partir de um método limpo, cuidadosamente triado e identificado.

\section{2- Procedimentos para a importação da escória de zinco e cobre no Brasil sob a égide da Convenção de Basiléia}

\section{1-Leis}

A Resolução CONAMA, número vinte e três de doze de dezembro de 1996, exige do país importador e do país exportador, interessado em movimentação de resíduos, a anuência do Instituto Brasileiro do Meio Ambiente e dos Recursos Naturais Renováveis (IBAMA) para a liberação do pedido do trânsito de materiais.

A resolução CONAMA citada deve ser preenchida em todo o seu conteúdo pelo país importador e pelo país exportador. Mas, para fins de análise do IBAMA, faz-se necessário o preenchimento do Anexo Cinco da resolução CONAMA 23/96 - Cadastro de importadores e processadores de material perigoso importado, do Anexo Seis - Documento do órgão de meio ambiente estadual atestando a situação ambiental da empresa (licença de funcionamento do órgão ambiental competente, licença de instalação do órgão ambiental competente e o auto de inspeção), do Anexo Sete - Informações de notificação previa para importação de material perigoso e do Anexo Oito - Previsão de importação de resíduos (em caso de freqüência curta para importação e exportação do resíduo).

Não podemos deixar de mencionar que a resolução classifica os resíduos em três categorias, tais como: perigosos-classe I, não inertes - classe II e inertes - classe III. Com relação a isto e sabendose que de acordo com a resolução mencionada, os resíduos de classes I e III são de importação 
proibida, classe II são controlados, sem esquecer de informar que a escória de zinco e de cobre, objeto de importação e, também, nosso estudo de caso são classificados como inertes (classe II) e para sua importação faz necessário o controle prévio do IBAMA.

Além da resolução CONAMA, as partes deverão cumprir as exigências estabelecidas nas normas da Associação Brasileira de Normas Técnicas (ABNT) denominadas NBR 10.004 - Caracterização dos Resíduos Sólidos, 10.005 - Procedimentos para obtenção de extrato lixiviado de resíduos sólidos, 10.006 - Procedimentos para obtenção de extrato solubilizado para resíduos e 10.007 Amostragem de resíduos sólidos. Todas foram reformuladas em 2004 e entraram em vigor com as novas alterações em 2005.

A fonte geradora de cobre primário, com código de identificação K 064, na norma NBR 10.004, tem por resíduos perigosos lodos e lamas do adensamento da purga ácida da produção do cobre primário. Os constituintes perigosos é o chumbo e o cádmio considerados tóxicos. Já 0 zinco primário com codificações K066, K067, K068, respectivamente gera resíduos perigosos de lodos provenientes do tratamento da purga ácida originada da produção do zinco primário e lodos calcários de anodos eletrolíticos originados da produção de zinco primário. Os constituintes perigosos presentes no zinco e cobre é o chumbo e o cádmio que apresentam em certos ambientes a característica de toxidade. Tal comportamento de toxidade pode ser verificado ao realizarmos 0 ensaio de lixiviação (Norma NBR 10.005 - Procedimentos para obtenção de extrato lixiviado de resíduos sólidos).

\section{2- Cadastro no Sistema de Comércio Exterior (SISCOMEX)}

Com a política econômica visando à abertura para o comércio internacional, o Governo Federal brasileiro determinou o desenvolvimento de um sistema de informações que integrasse as atividades dos principais órgãos: Departamento de Operações de Comércio Exterior (DECEX), Banco Central do Brasil (BACEN) e Secretaria da Receita Federal (SRF) ${ }^{82}$, de modo a uniformizar o tratamento

\footnotetext{
82 Convém lembrar que o Siscomex possui os dados Secretaria da Receita Federal (SRF), órgão do Ministério da Fazenda que na estrutura administrativa da República Federativa do Brasil cuida basicamente da formulação e execução da política econômica. A
} 
dado ao fluxo de informações de importação e de exportação. Assim, foi instituído o Sistema Integrado de Comércio Exterior (SISCOMEX) que representa uma nova sistemática administrativa para o comércio exterior brasileiro, vindo por intermédio da integração das atividades de várias instituições governamentais, referente à orientação, ao acompanhamento e ao controle das diferentes etapas das operações de importação e de exportação, inclusive câmbio. Este sistema informatizado preserva as funções básicas dos órgãos envolvidos, porém, com eliminação da coexistência de controles paralelos ao adotar o fluxo único de informações. Além disso, auxilia na aplicação completa, uniforme e justa da legislação, contribuindo para a melhoria dos controles e possibilitando uma agilização no desembaraço de mercadorias, como a redução do tempo de armazenamento e de liberação.

O SISCOMEX, instituído pelo Decreto $n^{0} 660$ de 1992 e planejado para ser implantado em $1^{0}$ de outubro de 1992, na parte relativa às exportações, entrou em funcionamento em quatro de janeiro de 1993. Este sistema abreviou os prazos de conclusão das operações comerciais, beneficiando as mais de oito mil empresas já usuárias do sistema e possibilitando ao Governo melhores controles e maior eficácia fiscal na exportação de mercadorias.

O importador da escória de cobre e zinco deverá solicitar ao sistema de comércio exterior o licenciamento de importação, documento que garante que o resíduo entrará no Brasil como matériaprima possível de reutilização e/ou reciclagem. Tal cadastro permite, também, a liberação da mercadoria para a alfândega dos portos.

\section{3-Taxa de controle de fiscalização ambiental}

A Taxa de Fiscalização Ambiental (TFA) foi instituída pela Lei 9960 de vinte e oito de janeiro de 2000. Por essa lei, pretende a União cobrar uma Taxa pelo serviço de fiscalização em empreendimentos com atividades potencialmente poluidoras ou consumidoras de recursos naturais. A empresa que não efetivar seu pagamento pode ficar sob pena de incorrerem em infração administrativa, prevista no Decreto Federal 3.179/99, entre outras sanções previstas na própria lei de crimes ambientais. O IBAMA é o órgão fiscalizador e, também, receptor da taxa de fiscalização. $\mathrm{Na}$

legislação em vigor - Decreto $n^{0} 5.136$, de sete de julho de 2004 - dispõe sobre a estrutura Regimental e o Quadro Demonstrativo dos Cargos em Comissão e das Funções Gratificadas do Ministério da Fazenda. Consulte o site do ministério da fazenda. www.fazenda.gov.br, acesso em treze de julho de 2005. 
obtenção da permissão da movimentação transfronteiriça de resíduos é necessário o recolhimento desta taxa, pois desde a empresa geradora de resíduos, transporte dos rejeitos e a empresa receptora de resíduos envolve a possibilidade de um acidente ambiental.

\section{4-Laudo de análise}

Além da resolução CONAMA, as partes deverão cumprir as exigências estabelecidas na norma ABNT 10.004 - Caracterização dos Resíduos Sólidos, 10.005 - Procedimentos para obtenção de extrato lixiviado de resíduos sólidos, 10.006 - Procedimentos para obtenção de extrato solubilizado para resíduos e 10.007 - Amostragem de resíduos sólidos mencionadas anteriormente. Para tal a empresa importadora deverá obter os laudos de análises de resíduos passíveis de importação para dar continuidade ao processo de movimentação transfronteiriça com laboratórios no Brasil certificados pelo Instituto Nacional de Pesos e Medidas (INMETRO) ${ }^{83}$. Desta forma, tal laudo conterá: identificação da composição química do produto, classificação tarifária do país receptor, nome do país de origem do resíduo, nome do país de recebimento do resíduo, aspecto de apresentação, nome comercial, formas de utilização, porcentagem de contaminação nela contida (como metais pesados), aplicabilidade do produto para necessária importação e demais informações que o laboratório ou os órgãos competentes julgarem pertinentes de inclusão.

\section{3- Casos de aplicação da Convenção no Brasil}

\section{1- Brasóxidos Indústria Química Ltda}

A empresa Brasóxidos Indústria Química Ltda localizada em Mauá, Estado de São Paulo, solicitou ao Instituto Brasileiro do Meio Ambiente e dos Recursos Naturais Renováveis (IBAMA) a permissão para importação de escória de zinco para continuidade de suas atividades em sua unidade de produção. A empresa atua na industrialização, comércio de produtos animais, exportação e importação de sucatas envolvendo o zinco e seus derivados. Desde agosto de 2001, a empresa encontrava dificuldades em localizar matéria-prima para seu funcionamento, deste modo, solicitou a movimentação transfronteiriça.

\footnotetext{
${ }^{83}$ Para maiores informações acesse http://www.inmetro.gov.br/inmetro/.
} 
Deste modo, iniciou-se junto ao IBAMA o processo de liberação de resíduos entre países sob a égide da Convenção de Basiléia. O país exportador era a Argentina, proveniente da empresa Sulfacid S.A., onde a sucata de zinco é originária do processo de fundição nesta empresa de placas anódicas de zinco. 0 primeiro passo foi a abertura do processo em território brasileiro, iniciando 0 preenchimento da resolução do Conselho Nacional do Meio Ambiente (CONAMA) de número vinte e três de doze de dezembro de 1996, onde nesta encontramos em seus anexos a classificação da tipologia do resíduo. As escórias de zinco são enquadradas nos rejeitos de classe II, passíveis de movimentação transfronteiriça segundo a liberação das autoridades ambientais competentes em território brasileiro. Deste modo, observe a seguir o artigo cinco da resolução mencionada:

A importação de itens da categoria de resíduos inertes, classe II, só poderá ser realizada para finalidades de reciclagem ou reaproveitamento após a autorização ambiental do IBAMA, precedida de anuência e parecer técnico do órgão estadual de meio ambiente.

Caso o resíduo solicitado para participar de movimentação transfronteiriça não se enquadrar na legislação brasileira que permite seu recebimento, este, em hipótese alguma, poderia direcionar-se para o território brasileiro sob condições legais.

Partindo do princípio que o resíduo pertencia a classe II, portanto passivel de movimentação, a empresa Brasóxidos iniciou o preenchimento do anexo cinco da resolução CONAMA já mencionada. $O$ anexo cinco contém os dados para o cadastro de importadores e processadores de material perigoso importado. Neste documento podemos ver os dados de localização da empresa exportadora, da empresa importadora, as descrições das atividades das duas empresas e a descrição do material perigoso a ser movimentado.

Após o preenchimento completo e aprovação do anexo cinco pelo IBAMA, a empresa importadora deverá apresentar sua licença de instalação e licença de funcionamento emitida pelo órgão ambiental no Brasil competente. Devido a empresa Brasóxidos localizar-se em Mauá, no Estado de São Paulo, o órgão ambiental competente para liberação desta documentação é a Companhia de Tecnologias de Saneamento Ambiental (CETESB). A empresa Brasóxidos apresentou sua licença de instalação e de funcionamento informando que utiliza a sucata de zinco para a fabricação de 
óxido de zinco e pó de zinco, bem como seu memorial de caracterização do empreendimento, em que podemos visualizar todos os processos que envolvem a sucata de zinco, tal como, os equipamentos utilizados em cada uma das etapas. A empresa Brasóxidos está devidamente coerente com as exigências técnicas estabelecidas pela CETESB no tocante a dispor de forma adequada seus resíduos sólidos industriais e no tratamento do material particulado proveniente da operação de fornos de fusão com o zinco.

O próximo passo é ainda dentro do preenchimento dos requisitos da resolução CONAMA de vinte e três de dezembro de 1996, que solicita o preenchimento de seu anexo seis denominado "Atestado de Situação Ambiental", também liberado pelo órgão estadual ambiental competente, no nosso estudo de caso, a CETESB. Neste atestado é confirmado que a empresa em questão encontra-se devidamente regularizada quanto a legislação ambiental pertinente para reciclar ou reprocessar resíduos de zinco a ser importados de forma ambientalmente segura.

O anexo sete desta resolução chamado de "Informações de notificação prévia para importação de resíduos controlados" deve ser preenchido e liberado pelo IBAMA. Neste encontraremos as localizações das empresas exportadoras e importadoras, a descrição do resíduo a ser importado, que no nosso caso são o óxido de zinco e o zinco metálico, seu código no Cadastro no Sistema de Comércio Exterior (SISCOMEX) e os requisitos especiais para manipulação humana com o resíduo passivel da movimentação transfronteiriça, que apenas necessita de máscaras para proteção contra o pó. Este anexo contém uma informação fundamental para a Convenção de Basiléia, pois ele informa todas os percursos terrestres, aéreos ou marítimos que uma carga venha a utilizar e, também, os dados da empresa transportadora. No nosso estudo de caso o rejeito saíra de Buenos Aires (Argentina) pela rota 11, rota 02 , rota 126, rota 127, rota 14 adentrando a ponte internacional e em território brasileiro as rodovias BR 472, BR 285, BR 153, BR 116 e transportado pela empresa Expresso Aguirucho S.A.

Por fim, o anexo oito é o último passo a ser preenchido sendo denominado "Previsão de importação de material perigoso". A empresa Brasóxidos realiza esta movimentação com certa freqüência. Informes registrados relatam que a empresa realizou movimentação transfronteiriça nos anos de 2001, 2002, 2003 e 2004 sempre atendendo suas necessidades de obtenção de matéria-prima. 
Outra exigência solicitada às empresas envolvidas na movimentação é a apresentação do laudo de análise da sucata a ser transportada e do recolhimento da taxa de fiscalização ambiental. Além disso, sem esse laudo fica impossível enquadrar o rejeito na classificação brasileira de caracterização dos resíduos. A empresa Brasóxidos apresentou esse laudo de análise da carga a ser transportada, elaborado pela Universidade Estadual de Campinas (UNICAMP) em anexo neste trabalho. É curioso saber que a empresa exportadora também apresentou, em território argentino, um laudo de análise da sucata importada para o Brasil, onde o leitor poderá visualizar no anexo deste trabalho. Conforme podemos reafirmar em legislação nacional a exigência do laudo de análise:

Laudo técnico de análise atestando a composição da carga de resíduos que esteja sendo importada, quando exigido pelo IBAMA, seguindo a resolução do CONAMA de vinte e três de dezembro de 1996.

No caso presente, a empresa Brasóxidos solicitou a importação da escória de zinco e, em vista do apresentado no laudo ao IBAMA, este instituto não teve nada a obstar contra a esta movimentação transfronteiriça já que a empresa concretizou todas as etapas solicitadas e mencionadas anteriormente com êxito.

Quanto à taxa de fiscalização ambiental, menciona-se que a empresa que não efetivar seu pagamento pode ficar sob pena de incorrerem em infração administrativa, prevista no Decreto Federal 3.179/99, entre outras sanções previstas na própria lei de crimes ambientais. A empresa Brasóxidos realizou o recolhimento desta taxa.

O Cadastro no SISCOMEX é o último passo para a liberação da movimentação transfronteiriça considerada a sucata de zinco como rejeito permitido de realizar a movimentação transfronteiriça, encaixando-se no código 26.20 .1900 denominado outras cinzas e resíduos contendo zinco. A escória de zinco entre a empresa Brasóxidos e a empresa Sulfacid assume em território nacional este código podendo ser comercializada, portanto como matéria-prima e não mais como resíduo a ser disposto em território brasileiro. 0 regime de tributação da mercadoria neste caso é o mesmo empregado para matérias-primas não secundárias não havendo nenhuma isenção de ordem 
tributária. Apenas com a anuência do IBAMA, o extrato de licenciamento de importação é liberado. Neste extrato além de informar o código da mercadoria, informa também o local de recebimento em território brasileiro da sucata que no caso entrará no Brasil pelo município de Uruguaiana, no Rio Grande do Sul.

Após preencher todos os requisitos solicitados anteriormente neste capítulo a empresa conseguiu a liberação do lote da sucata mencionada de procedência da Argentina para o Brasil. Nos anexos deste trabalho, o leitor tem acesso aos laudos de análise da sucata na Argentina e no Brasil, e também o parecer técnico final do IBAMA para liberação da movimentação transfronteiriça.

\section{2- Ferreira Elias Representações Ltda}

A empresa Ferreira Elias Representações Ltda, localizada em Belo Horizonte, no Estado de Minas Gerais, solicitou ao Instituto Brasileiro do Meio Ambiente e dos Recursos Naturais Renováveis (IBAMA) a permissão para importação de resíduos de cobre para continuidade de suas atividades em sua unidade de produção. A empresa atua na compra e venda da sucata de metais ferrosos e não ferrosos, sendo sua atividade principal, também, a fundição e laminação do cobre. Em 2004, a empresa encontrava dificuldades em localizar matéria-prima para seu funcionamento, deste modo, solicitando a movimentação transfronteiriça.

Deste modo, iniciou-se junto ao IBAMA o processo de liberação de resíduos entre países sob a égide da Convenção de Basiléia. O país exportador era o Reino Unido proveniente da empresa London Metals Limited, onde a sucata de cobre é fruto de sua atividade industrial. O primeiro passo foi a abertura do processo em território brasileiro no IBAMA, iniciando o preenchimento da resolução do Conselho Nacional do Meio Ambiente (CONAMA) de número vinte e três de doze de dezembro de 1996, em que encontramos em seus anexos a classificação da tipologia do resíduo. Os resíduos de cobre são enquadrados nos rejeitos de classe II, passíveis de movimentação transfronteiriça, segundo a liberação das autoridades ambientais competentes em território brasileiro. Deste modo, observe a seguir o artigo cinco da resolução mencionada: 
A importação de itens da categoria de resíduos inertes, classe II, só poderá ser realizada para finalidades de reciclagem ou reaproveitamento após a autorização ambiental do IBAMA, precedida de anuência e parecer técnico do órgão estadual de meio ambiente.

Caso o resíduo solicitado para participar de movimentação transfronteiriça não se enquadrasse na legislação brasileira que permite seu recebimento, este, em hipótese alguma, poderia direcionar-se para o território brasileiro sob condições legais.

Partindo do princípio que o resíduo pertencia a classe II, portanto passível de movimentação a empresa Ferreira Elias Representações Ltda iniciou o preenchimento do anexo cinco da resolução CONAMA já mencionada. $O$ anexo cinco contém os dados para o cadastro de importadores e processadores de material perigoso importado. Neste documento podemos ver os dados de localização da empresa exportadora, da empresa importadora, as descrições das atividades das duas empresas e a descrição do material perigoso a ser movimentado.

Após o preenchimento completo e aprovação do anexo cinco pelo IBAMA, a empresa importadora deverá apresentar sua licença de instalação e licença de funcionamento emitida pelo órgão ambiental no Brasil competente. Devido a empresa Ferreira Elias Representações Ltda possuir sua unidade processadora de resíduos em Várzea Paulista, no Estado de São Paulo, e não em Belo Horizonte, o órgão ambiental competente para liberação desta documentação é a Companhia de Tecnologias de Saneamento Ambiental (CETESB). A empresa Ferreira Elias Representações Ltda apresentou sua licença de instalação e de funcionamento informando que utiliza a sucata de cobre para a fundição e laminação, bem como seu memorial de caracterização do empreendimento, em que podemos visualizar todos os processos envolvendo a sucata de cobre, e também os equipamentos utilizados em cada uma das etapas. A empresa Brasóxidos está devidamente coerente com as exigências técnicas estabelecidas pela CETESB no tocante a dispor de forma adequada seus resíduos sólidos industriais e no tratamento do material particulado proveniente da operação de fornos de fusão com o cobre.

O próximo passo é ainda dentro do preenchimento dos requisitos da resolução CONAMA, de vinte e três de dezembro de 1996, que solicita o preenchimento de seu anexo seis denominado "Atestado de Situação Ambiental", também liberado pelo órgão estadual ambiental competente, no nosso 
estudo de caso, a CETESB. Neste atestado é confirmado que a empresa em questão encontra-se devidamente regularizada quando a legislação ambiental pertinente para reciclar ou reprocessar resíduos de zinco a ser importado de forma ambientalmente segura. A empresa Ferreira Elias Representações Ltda até a presente data não preencheu esta etapa do processo.

O anexo sete desta resolução chamado de "Informações de notificação prévia para importação de resíduos controlados" deve ser preenchido e liberado pelo IBAMA. Neste encontraremos as localizações das empresas exportadoras e importadoras, a descrição do resíduo a ser importado, que no nosso caso são fios e cabos elétricos de cobre, seu código no Cadastro no Sistema de Comércio Exterior (SISCOMEX) e os requisitos especiais para manipulação humana com o resíduo passível da movimentação transfronteiriça, que neste caso não mencionou a necessidade de nenhum equipamento de segurança. Este anexo contém uma informação fundamental para a Convenção de Basiléia, pois ele informa todas os percursos terrestres, aéreos ou marítimos que uma carga venha a utilizar e também os dados da empresa transportadora. No nosso estudo de caso o rejeito sairá do Reino Unido em contêineres e transportado pela empresa Tradertop S.A. até o território brasileiro.

Por fim, o anexo oito é o último passo a ser preenchido, sendo denominado "Previsão de importação de material perigoso". A empresa Ferreira Elias Representações Ltda pretende realizar esta movimentação com freqüência nos anos de 2004 e 2005.

Outra exigência solicitada às empresas envolvidas na movimentação é a apresentação do laudo de análise da sucata a ser transportada e do recolhimento da taxa de fiscalização ambiental. Além disso, sem o laudo fica impossível enquadrar o rejeito na classificação brasileira de caracterização dos resíduos. A empresa Ferreira Elias Representações Ltda até maio de 2005 não havia apresentado ao IBAMA o laudo de análise da carga a ser transportado elaborado em território nacional. Ainda é curioso que a empresa exportadora também apresentou um laudo de análise londrino da sucata importada para o Brasil que o leitor poderá visualizar no anexo deste trabalho. Conforme podemos reafirmar em legislação nacional a exigência do laudo de análise: 
Laudo técnico de análise atestando a composição da carga de resíduos que esteja sendo importada, quando exigido pelo IBAMA, seguindo a resolução do CONAMA de vinte e três de dezembro de 1996.

No caso da empresa Ferreira Elias Representações Ltda esta solicitou a importação da sucata de cobre em vista do apresentado ao IBAMA, até maio de 2005, que obstou com algumas considerações para que esta movimentação transfronteiriça seja liberada. Diante das alterações no que concerne aos procedimentos nacionais para controle da importação de resíduos, tal empresa para concluir a movimentação transfronteiriça deverá apresentar os laudos de análise de resíduos para cada unidade geradora conforme as NBRS 10.004, 10.005, 10.006e 10.007 além da apresentação de informações sobre o resíduo, sobre o exportador do resíduo e sobre o gerador e 0 local de geração mencionadas na resolução CONAMA 23 de doze de dezembro de 1996. Nos anexos deste trabalho, consta o parecer técnico final do IBAMA para liberação da movimentação transfronteiriça. Para que a empresa Ferreira Elias Representações Ltda prossiga para alcançar a movimentação transfronteiriça deverá preencher as normas de identificação de resíduos conforme as normas da Associação Brasileira de Normas Técnicas (ABNT) mencionadas anteriormente.

Somente com o laudo de análise laboratorial, segundo as normas da ABNT, a empresa Ferreira Elias Representações Ltda conseguirá a permissão para desembarque dos resíduos de cobre na alfândega dos portos brasileiro. A empresa, até maio de 2005, não havia conseguido esta etapa, pois ainda tinha pendências com o IBAMA quanto a apresentação do laudo conforme legislação ambiental em vigor no território brasileiro.

Quanto à taxa de fiscalização ambiental, menciona-se que a empresa que não efetivar seu pagamento pode ficar sob pena de incorrerem em infração administrativa, prevista no Decreto Federal 3.179/99, entre outras sanções previstas na própria lei de crimes ambientais. A empresa Ferreira Elias Representações Ltda realizou o recolhimento desta taxa.

O Cadastro no SISCOMEX é o último passo para a liberação da movimentação transfronteiriça que considera a sucata de cobre como rejeito permitido de realizar a movimentação transfronteiriça, encaixando-se no código 740.400.00 denominado sucatas de cobre. A sucata de cobre existente entre a empresa Ferreira Elias Representações Ltda e a empresa London Metals Limited assume 
em território nacional este código podendo ser comercializada, portanto como matéria-prima e não mais como resíduo a ser disposto em território brasileiro. 0 regime de tributação da mercadoria neste caso é o mesmo empregado para matérias-primas não secundárias, não havendo nenhuma isenção de ordem tributária. Apenas com a anuência do IBAMA o extrato de licenciamento de importação é liberado. Neste extrato além de informar o código da mercadoria, informa também 0 local de recebimento em território brasileiro da sucata importada. A empresa Ferreira Elias Representações Ltda, até maio de 2005 , não havia conseguido esta etapa, pois ainda tinha pendências com o IBAMA. 


\section{CONSIDERAÇÕES FINAIS}

\section{Consciência ambiental e mudanças de paradigmas}

O aparecimento acentuado de problemas com a disposição de resíduos sólidos no Brasil e no mundo aponta para a necessidade da criação de políticas, convenções e tratados para auxiliar em sua gestão. Todas as políticas públicas brasileiras para a gestão de resíduos sólidos industriais devem considerar a questão da segurança e considerar a Convenção de Basiléia sobre o Controle de Movimentos Transfronteiriços de Resíduos Perigosos e Disposição Final. Para isto, a racionalidade técnica associada ao conhecimento da realidade brasileira da geração de resíduos sólidos perigosos deve sempre ser considerada por técnicos, parlamentares, ongs, empresas e sociedade civil, que somados serão os realizadores e formadores das políticas nacionais que vigorarão no Brasil para a questão. Somente assim teremos "A Convenção de Basiléia sobre 0 Controle de Movimentos Transfronteiriços de Resíduos Perigosos e Disposição Final" internalizada e podendo contribuir para o gerenciamento dos resíduos industriais no País.

Como sabemos o Brasil não possui uma política nacional de resíduos sólidos. A falta de uma lei federal que trate da gestão ambientalmente segura dos resíduos sólidos tem trazido insegurança jurídica nos atos da administração pública. Neste sentido, entendemos que tal lei venha dar segurança jurídica necessária à área, ou seja, será um efetivo marco regulatório em que deverá abordar os seguintes requisitos: aspectos econômicos, financeiros, administrativos e de qualificação profissional dos gestores técnicos ambientais do Estado, questões sociais, culturais de participação da sociedade e de responsabilidade perante o material pós-consumo, interface com as demais áreas do saneamento, preocupação com a contaminação do ar, água e solo, legalização da fiscalização e controle sociais sobre produtos produzidos e comercializados.

Nossas considerações finais serão posicionadas diante de sete itens: a capacitação dos órgãos ambientais públicos em todas as suas esferas sobre a Convenção e seus itens; a existência de tecnologia adequada no país de origem, tanto para o aproveitamento como para o processamento; a existência de política nacional contemplando a temática; a existência de incentivos fiscais para o uso 
de tecnologias limpas; a associação de um determinado grupo de países para utilizar, em conjunto instalações de aproveitamento e eliminação e as manutenções feitas por empresas multinacionais e filiais de tecnologia de tratamento e disposição final nos países em desenvolvimento e por fim a escolha de múltiplas escalas para a compreensão da movimentação de resíduos sólidos. Certamente nosso leitor diante da leitura deste trabalho poderá formular outros posicionamentos não informados até então. No entanto, tais itens mencionados são prioridades para manter a vitalidade do tratado na ordem ambiental internacional bem como para a internalização da Convenção no Brasil. Sendo assim:

\section{Capacitaç̃o dos órgãos ambientais públicos em todas as suas esferas sobre a Convenção e} seus itens:

No Brasil, os sistemas ambientais estaduais não foram revigorados na década de 1990, agravando assim a questão da auto-sustentabilidade financeira. Projetos de fortalecimento institucional esbarram nas deficiências e no esvaziamento da administração pública nacional e estadual. Praticase a reforma do Estado sem uma nova proposta de regulação pública para a questão ambiental. Investimentos em programas de gestão da qualidade ambiental são dependentes de financiamento. Aplicam-se recursos em estruturas deficitárias, que não os podem utilizar para corrigir problemas estruturais: carência de recursos técnicos, deficiências de reciclagem e salários baixos. Os números de licenças ambientais realizados são crescentes, mas avalia-se a qualidade ambiental na maior parte dos casos exclusivamente pelas emissões das fontes poluidoras. Aplica-se de forma insuficiente o planejamento e a avaliação da qualidade ambiental dos ambientes, e esta deficiência reduz a importância social das agências e sua capacidade de interferência nas políticas públicas. ${ }^{84}$

Deste modo à capacitação e a liberação de recursos para estes órgãos permite não somente a elaboração de licenciamentos, punições e fiscalizações quando necessário, mas também proporciona a conscientização dos setores geradores de resíduos industriais para a importância da gestão dos mesmos à luz da Convenção.

\footnotetext{
${ }^{84}$ MAGLIO, A. Descentralização da Gestão Ambiental no Brasil: o papel dos órgãos estaduais e as relações com o poder local de 1990 a 1999. São Paulo: Tese de Mestrado. Universidade de São Paulo. 2000. 270 pg. Indicamos como leitura: MONTEIRO, R. e ZIGLIO L. A política nacional de resíduos sólidos brasileira . Monografia. Disciplina Política e Gestão Ambiental. Faculdade de Saúde Pública. Universidade de São Paulo. 2002.41pg.
} 
Existência de tecnologia adequada no país de origem tanto para aproveitamento como para processamento:

A tecnologia de recuperação ou reciclagem instalada no país de origem seria um dos instrumentos favoráveis para evitarmos a movimentação transfronteiriça de resíduos. Sendo assim o Brasil não receberia em hipótese alguma resíduo advindo de outros países e também não conseguiria exportálos favorecendo ainda mais a proibição presente na Convenção e assinada pelos Estados-Partes.

Política nacional contemplando a temática:

Como mencionamos ao longo do trabalho, o Brasil não possui uma política nacional de resíduos sólidos. A ausência da lei facilita a prática de certos procedimentos relacionados à gestão dos resíduos que ficariam limitados caso a lei existisse. Um bom exemplo é o caso dos pneus inservíveis mencionados, regulados pela resolução CONAMA, número 258 de vinte e seis de agosto de 1999, que torna obrigatório às empresas fabricantes e importadoras de pneumáticos coletar e dar destino final ambiental adequado aos pneus insensíveis no País. A lei nacional, neste caso, reforçaria ainda mais o caráter proibitivo e a efetiva gestão destes materiais. Além disso, a lei nacional permitiria estimular a gestão dos diversos resíduos gerados no País.

\section{Incentivos fiscais para o uso de tecnologias limpas:}

A isenção fiscal ou a diminuição da alíquota de impostos para o setor industrial que aplicar em sua produção o uso de tecnologias limpas é um dos caminhos ao estímulo desta prática. Linhas de financiamento para a aquisição de equipamentos com este perfil também permitiriam o acesso mais amplo do setor empresarial ao seu uso. Assim como existe o ICMS Ecológico em alguns estados brasileiros estimulando com a geração de seus recursos a coleta seletiva dos municípios, talvez 0 mesmo pudesse ser feito com os resíduos industriais. 
Associação de um determinado grupo de países para utilizar em conjunto instalações de aproveitamento e eliminação:

A existência de instalações em que os estados partes da Convenção de Basiléia pudessem utilizar em conjunto seria uma das possibilidades para a gestão dos resíduos industriais. No entanto, teríamos aqui um fator perigoso, que seria o local de instalação deste parque de tecnologias que poderia transmitir sérios impactos ambientais e humanos no país sede, caso este não recebe 0 amparo necessário para a manutenção deste complexo. Neste sentido, a criação de um fundo internacional para assegurar a consolidação deste pensamento seria fundamental.

\section{Manutenção feita por empresas multinacionais filiais de tecnologia de tratamento e disposição} final nos países em desenvolvimento:

Temos exemplos de empresas multinacionais que utilizam tecnologias de ponta em suas matrizes enquanto nas filiais o mesmo não acontece. Muitas destas empresas hoje não praticam esta atitude mencionada anteriormente para garantir a qualidade de competitividade de seus produtos, no entanto, com a questão ambiental ainda não verificamos esta igualdade tecnológica vista quando nos referimos ao plano econômico. Isto, de forma exemplificada, indica que uma empresa num país pode utilizar as tecnologias ambientais e em uma outra unidade desta empresa em um outro país não tenha o mesmo comportamento. A padronização das tecnologias, que poderia ser indicada pela Convenção, através de seus grupos técnicos de trabalho permitiria a aplicação, manutenção de tecnologias limpas.

\section{A escolha e a aplicação de múltiplas escalas:}

Sociedades de consumo são sinônimas de produção de resíduos. Em diversas escalas, mundial, nacional e municipal, esse processo resulta em imensos depósitos de materiais que degradam 0 ambiente pela simples disposição inadequada. O nosso tema exige a aplicação de inúmeras escalas para sua compreensão, pois atinge a dimensão mundial ao regular o trânsito de resíduos entre países, a dimensão nacional por solicitar a incorporação de diretrizes presentes na Convenção nas leis nacionais brasileiras, e por fim municipal, por pedir através dos órgãos ambientais brasileiros a 
organização na esfera do município da gestão dos resíduos industriais. Esta multiplicidade das escalas que o tema de nossa dissertação solicita é fundamental para a efetiva compreensão de sua existência e também de sua forma de ação no cenário da gestão de resíduos do país. Quando as escalas de análise mudam percebemos o tamanho do objeto que estudamos e ainda mais podemos perceber o seu modo de interagir com a realidade. Pensando especificamente na Convenção de Basiléia, ao analisarmos esta na escala mundial conseguimos entender seus objetivos e aplicações para todos os países, quando diminuímos a escala de análise para a esfera nacional, escolhemos apenas um estado para entender as conseqüências da aplicação deste tratado em sua realidade que permeará com os novos desdobramentos da escala até a sua inserção ao nível municipal. Essa escolha de escalas deve ser vista como a busca do geógrafo em compreender ainda mais a realidade por ele analisada. Neste sentido em nossos estudos julgamos a necessidade da aplicação de inúmeras escalas para o completo entendimento do funcionamento da Convenção. Deste modo gostaríamos de mencionar os dizeres de Castro para encerramento de nossa discussão:

A análise geográfica dos fenômenos requer objetivar os espaços na escala em que eles são percebidos. ${ }^{85}$

Mas, todos os tópicos descritos em nossas palavras finais são paliativos. O que realmente necessitamos é da mudança de paradigmas para efetiva obtenção da proteção ambiental e humana. Deste modo, encerramos com a citação de ALTVATER:

Os impasses da civilização atual estão, em última instância, baseados no dogma ocidental da expansão ilimitada dos desejos e das necessidades. Sem, por isso, procurar voltar a um estado "primitivo" ou "selvagem", tornou-se necessário redefinir esses desejos e necessidades e orientar-se, consciente e voluntariamente, para sua limitação... Esse novo paradigma supõe uma mudança radical nos valores, tanto em nível individual como coletivo. Noções como as de poupança, serviço, dádiva, gratuidade e eqüidade devem tornar-se as alavancas principais da ação individual. 0 crescimento pelo crescimento, as técnicas de manipulação de massa, a fuga nas ciências e na técnica, a generalização ilimitada do trabalho são geradoras de necessidades artificiais e devem, portanto, ser contestadas ou abandonadas. ${ }^{86}$

\footnotetext{
${ }^{85}$ CASTRO I. E. et. al. Geografia: Conceitos e Temas, São Paulo: Bertrand Brasil, 1995. pg.120.0

${ }^{86}$ ALTVATER, E. O preço da riqueza. São Paulo, UNESP, 1995. pg.91.
} 
$\underline{\text { Referências Bibliográficas }}$

ABETRE Associação Brasileira de Empresas de Tratamento de Resíduos. Pará virou lixeira do Brasil, com a usina de Ulianópolis. In: www.abetre.com.br . São Paulo. Internet, 4/08/2002

AGENDA 21, capítulo 20, Introdução, item 20.1, pg. 1. Acesso em www.mma.gov.br/agenda21 em 28.11.2002.

ALTVATER, E. O preço da riqueza. São Paulo, UNESP, 1995.

ARON R. Paz e guerra entre as nações . Brasília: Universidade de Brasília, 1986.

BARBIERI, J. C. Desenvolvimento e Meio Ambiente. São Paulo: Vozes, 1997.

CASTRO I. E. et. al. Geografia: Conceitos e Temas , São Paulo: Bertrand Brasil, 1995.

COMISSÃO MUNDIAL SOBRE MEIO AMBIENTE E DESENVOLVIMENTO. Nosso Futuro Comum. Rio de Janeiro, Fundação Getúlio Vargas, 1991, pg.46.

DERANI, C. Direito Ambiental Econômico. São Paulo, Max Limonad, 2001.

CONVENÇÃO da Basiléia sobre o controle de movimentos transfronteiriços de resíduos e seu depósito. Secretaria do Meio Ambiente, São Paulo, 1997.

CONSTITUIÇÃO da República Federativa do Brasil. 1988.

DINIZ E. M. O Brasil e a Rio +10. Revista do Departamento de Geografia, USP, 2002.

DRAFT Declaration submitted by the President of the Summit, Johannesburg, 4 September, 2002, principles one and seventeen.

DUPUY, J. Introdução a critica da ecologia política. Rio de Janeiro, Civilização Brasileira, 1980.

ELLIOTT, L. The Global Politics and Environment. .Macmillan, 1998.

FERREIRA, G. Natureza jurídica e definição de resíduos perigosos na convenção de Basiléia. São Paulo. Universidade de São Paulo. 2003.

GARCÍA-TORNEL, Francisco Calvo. Sociedades y territorios en riesgo. Barcelona, Ediciones del Serbal, 2001.

GONÇALVES, C. Os (des) caminhos do meio ambiente. Editora Contexto, São Paulo, 1.996. 
GONÇALVES, C. Geografia política e desenvolvimento sustentável. Revista Terra Livre, São Paulo, vl. 11-12 de agosto de 1993.

GUIDO, F.S. Direito Internacional do Meio Ambiente: Emergência, Obrigações e Responsabilidades. São Paulo, Atlas, 2001.

HUNTINGTON, S. The Clash of Civilizations and the Remaking of World Order. New York, Touchstone Book, 1997.

JORNAL The New York Times Nova York retoma programa de reciclagem do lixo. São Paulo, acesso em 25.07.2003.

KENNAN, G. Morality and foreign policy, Foreign Affairs, 64 (2), 1995.

LE PRESTRE, Philippe. Ecopolítica internacional. São Paulo, SENAC, 2000.

LEFF, H. Saber Ambiental: sustentabilidade, racionalidade, complexidade e poder. Rio de Janeiro: Vozes, 2001. pg.46.

LEFF, H. Ecologia, Capital e Cultura. Blumenau, Furb. 2000.

MARTIN, A. Fronteiras e Nações. São Paulo, Contexto, 1992.

MORGENTHAU, H. Politics among nations: the struggle for power and peace. New York, Alfred Knopf, 1973.

MOKHIBER, R. O Caso Bhopal. S.n.s.d. $5 p$.

MOKHIBER, R. O Caso Minamata. S.n.s.d. 4p.

ORGANIZAÇÃO PARA COOPERAÇÃO E DESENVOLVIMENTO ECONÔMICO (OECD) Waste Management Policy Group, Working Paper, number 3, for the 37 th meeting, march, 1993.

REVISTA L Usine Nouvelle, Lês acteurs du recyclage parient sur une envolee.Avril de 1999.

REVISTA Ciência Hoje on-line, Reciclagem de Pilhas, In: www.uol.com.br/cienciahoje de 13.10.03, acesso em 13.07 .05

RIBEIRO, W.C. A ordem ambiental internacional. São Paulo: Contexto, 2001.

RIBEIRO, W.C. O Brasil e a Rio +10. Revista do Departamento de Geografia, Universidade de São Paulo, 2002.

RIBEIRO, W.C. Trabalho e ambiente: novos profissionais ou nova demanda? . Revista electrónica de geografía y ciencias sociales .Universidad de Barcelona, Vol. VI, num. 119 (98), 2002. 
RIBEIRO, H. e GUNTHER, W. Urbanização, Modelo de Desenvolvimento e a Problemática dos Resíduos Sólidos Urbanos.In: Patrimônio Ambiental Brasileiro, Edusp, São Paulo, 2003. pg. 469489.

SACHS, I. Estratégias de transição para o século XXI: desenvolvimento e meio ambiente. São Paulo, Nobel, 1993.

SANTOS, M. Metamorfoses do espaço habitado. São Paulo, Hucitec, 1997.

SANEAMENTO BÁSICO NA INTERNET. Lixo Tóxico preocupa empresas da Zona Franca de Manaus. www.saneamentobasico.com.br . São Paulo, acesso em 29/10/2002.

STEIGLEDER, A. Aspectos Jurídicos da Reparação de Áreas Contaminadas por Resíduos Industriais. Revista de Direito Ambiental, São Paulo, Editora Revista dos Tribunais. Janeiro -março 2003, ano oito, número 29.

VALLE, C. Resíduos Perigosos no Brasil. Primeiro Guia de Tecnologias Ambientais Brasil e Alemanha. 2000. Câmara do Comércio Brasil e Alemanha, São Paulo. 


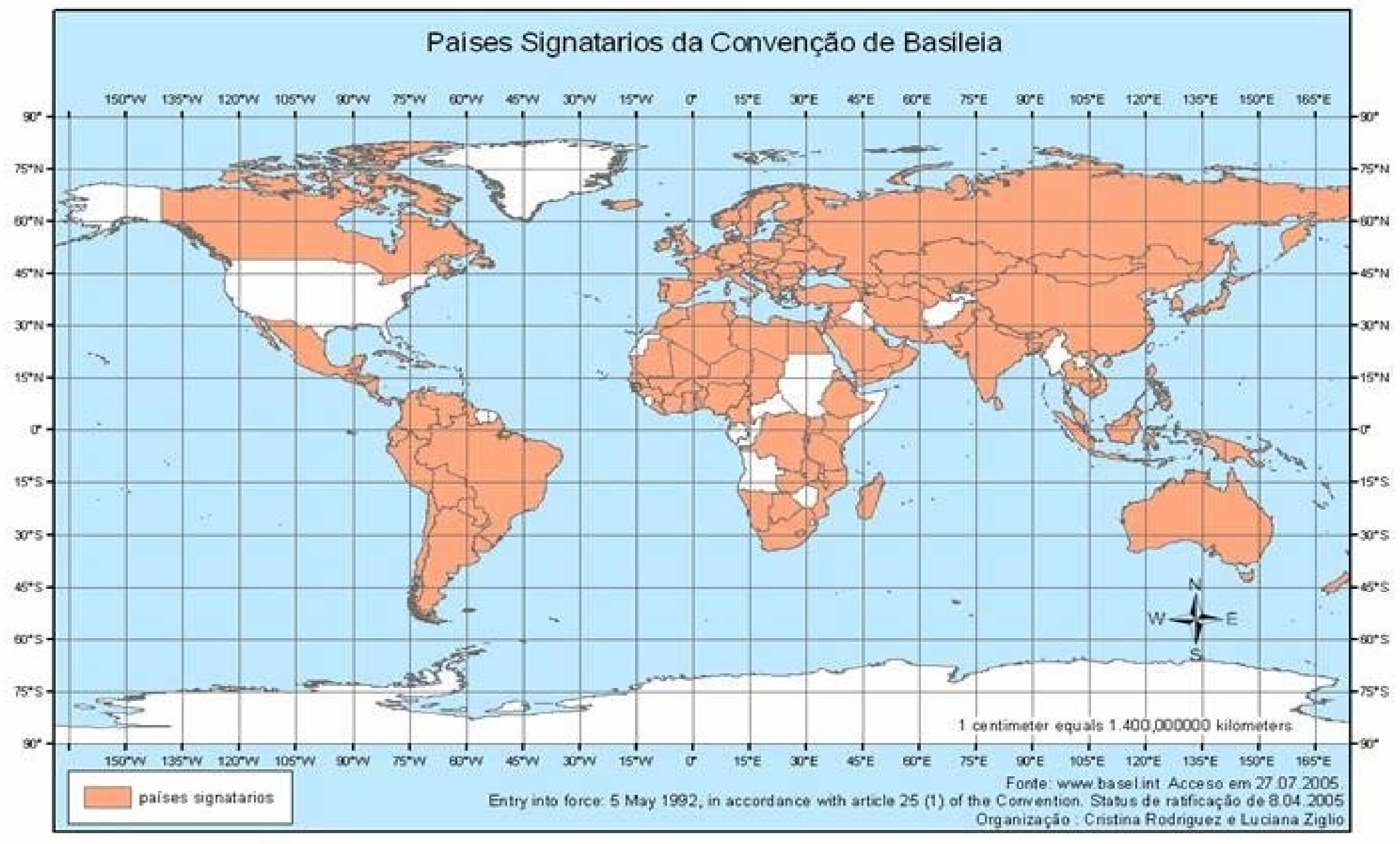


ANEXOS 
Instrumentos Legais no Brasil da Convenção (continua)

\begin{tabular}{|c|c|c|}
\hline Decreto-Lei & 2.063, de 06/10/83, Publicado em 07/10/83 & $\begin{array}{l}\text { Dispõe sobre multas por infrações à } \\
\text { regulamentação devido ao transporte } \\
\text { rodoviário de carga de produtos perigosos. } \\
\text { (em vigência) }\end{array}$ \\
\hline Lei Federal & 7.802 de 11.07 .89 & $\begin{array}{l}\text { Regulamenta desde a pesquisa e } \\
\text { fabricação dos agrotóxicos até sua } \\
\text { comercialização, aplicação, controle, } \\
\text { fiscalização e também o destino da } \\
\text { embalagem. (Regulamentada pelo } \\
\text { Decreto } 4.074 \text { de 04/01/2002, em } \\
\text { vigência) }\end{array}$ \\
\hline CONAMA & $n^{\circ} 08$ de 19/9/91, publicada em 30/10/91. & $\begin{array}{l}\text { É vedada a entrada no País de } \\
\text { materiais residuais destinados à } \\
\text { disposição final e incineração no } \\
\text { Brasil. (em vigência) }\end{array}$ \\
\hline Decreto & n. ${ }^{\circ} 875$ de $19 / 7 / 93$, publicado em 20/7/93 & $\begin{array}{l}\text { Promulga o texto da Convenção e } \\
\text { manifesta preocupação ante as } \\
\text { deficiências do texto que contém } \\
\text { dispositivos excessivamente flexíveis } \\
\text { como os artigos } 4 \text { e 11. (em vigência) }\end{array}$ \\
\hline
\end{tabular}


Instrumentos Legais no Brasil da Convenção (continua)

\begin{tabular}{|c|c|c|}
\hline CONAMA & Resolução n. 7 de 4-5-94, & $\begin{array}{l}\text { Proíbe a importação e exportação de } \\
\text { resíduos perigosos, de qualquer espécie sob } \\
\text { qualquer forma e para qualquer fim, inclusive } \\
\text { para incineração. (Revogada pela Resolução } \\
\text { CONAMA n } 37 / 94 \text { também revogada pela } \\
\text { resolução CONAMA 23.12.96 em vigência) }\end{array}$ \\
\hline CONAMA & n. ${ }^{0} 19$ de 29/9/94 & $\begin{array}{l}\text { Autoriza a exportação de resíduos perigosos } \\
\text { contendo bifenilas policloradas PCB até } \\
31 / 12 / 97 \text {, devendo obedecer aos } \\
\text { procedimentos da Portaria Normativa n. } \\
\text { 138-N. (em vigência) }\end{array}$ \\
\hline Portaria Normativa & $\begin{array}{l}\text { n. }{ }^{0} 138-\mathrm{N} \text { do IBAMA, de 22/12/92, publicada } \\
\qquad \text { em 23/12/94 }\end{array}$ & $\begin{array}{l}\text { Proíbe a importação de determinados } \\
\text { resíduos listados e estabelece } \\
\text { procedimentos que normatizam a } \\
\text { importação e a exportação de outros } \\
\text { resíduos. (revogada pela resolução } \\
\text { Conama } \text {. }^{\circ} 37 \text { de } 30 / 12 / 94 \text { também } \\
\text { revogada e substituída pela } \\
\text { resolução CONAMA } 23.12 .96 \text { em } \\
\text { vigência)) }\end{array}$ \\
\hline
\end{tabular}


Instrumentos Legais no Brasil da Convenção (continua)

\begin{tabular}{|c|c|c|}
\hline CONAMA & n. ${ }^{0} 37$ de 30/12/94 & 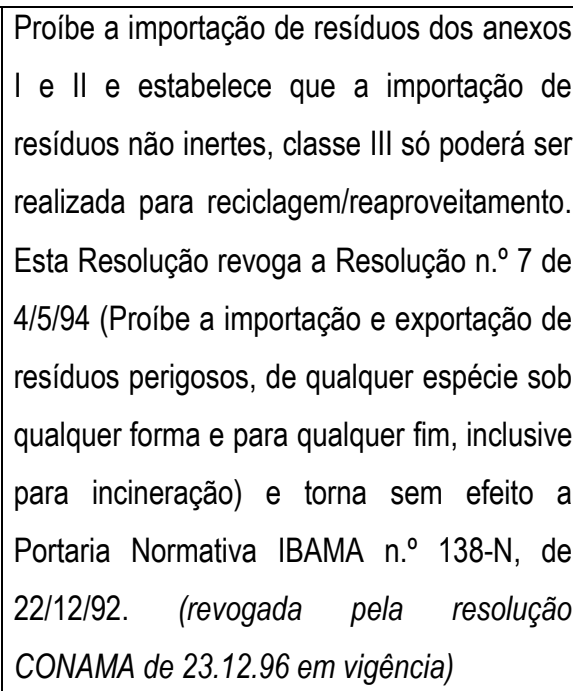 \\
\hline CONAMA & n. ${ }^{\circ} 8$ de $11 / 08 / 96$ & $\begin{array}{l}\text { Autoriza, em caráter excepcional, por } \\
\text { seis meses, a importação de } 66.500 \\
\text { toneladas de sucatas de chumbo, } \\
\text { sob a forma de baterias automotivas } \\
\text { usadas, para } \\
\text { reciclagem/reaproveitamento.(Revog } \\
\text { ada pela resolução Conama } n .^{\circ} 21 \text {, } \\
\text { de } 24 / 10 / 96)\end{array}$ \\
\hline CONAMA & n. ${ }^{0} 21$, de 24/10/96 & $\begin{array}{l}\text { Suspende a Resolução } n^{0} 8 \text { de } \\
11 / 08 / 96 \text { (Autoriza, em caráter } \\
\text { excepcional, por seis meses, a } \\
\text { importação de } 66.500 \text { toneladas de } \\
\text { sucatas de chumbo) (em vigência) }\end{array}$ \\
\hline
\end{tabular}


Instrumentos Legais no Brasil da Convenção (continua)

\begin{tabular}{|c|c|c|}
\hline CONAMA & n. ${ }^{\circ} 23$, de $12 / 12 / 96$ & $\begin{array}{l}\text { Proíbe a importação de resíduos perigosos e } \\
\text { outros resíduos e estabelece restrições à } \\
\text { importação de resíduos inertes (à exceção } \\
\text { dos pneumáticos usados, cuja importação é } \\
\text { proibida). A importação de resíduos não } \\
\text { inertes só poderá ser realizada para } \\
\text { reciclagem e reaproveitamento após } \\
\text { autorização do IBAMA, precedida de } \\
\text { anuência do Órgão Estadual de Meio } \\
\text { Ambiente e após atender diversas } \\
\text { exigências. A Resolução especifica ainda os } \\
\text { resíduos, relacionados na nomenclatura } \\
\text { comum do Mercosul baseado no sistema } \\
\text { harmonizado NCM-SH, que dependerão de } \\
\text { aprovação do IBAMA e da SECEX/MICT. } \\
\text { Esta em vigência revoga a Resolução no } 37 \\
\text { de } 30 / 12 / 94 \text { (Proíbe a importação de } \\
\text { resíduos dos anexos I e II e estabelece que } \\
\text { a importação de resíduos não inertes, classe } \\
\text { III só poderá ser realizada para reciclagem e } \\
\text { reaproveitamento revogada pela resolução } \\
\text { CONAMA } 23.12 .96 \text { em vigência) }\end{array}$ \\
\hline
\end{tabular}


Instrumentos Legais no Brasil da Convenção (conclusão)

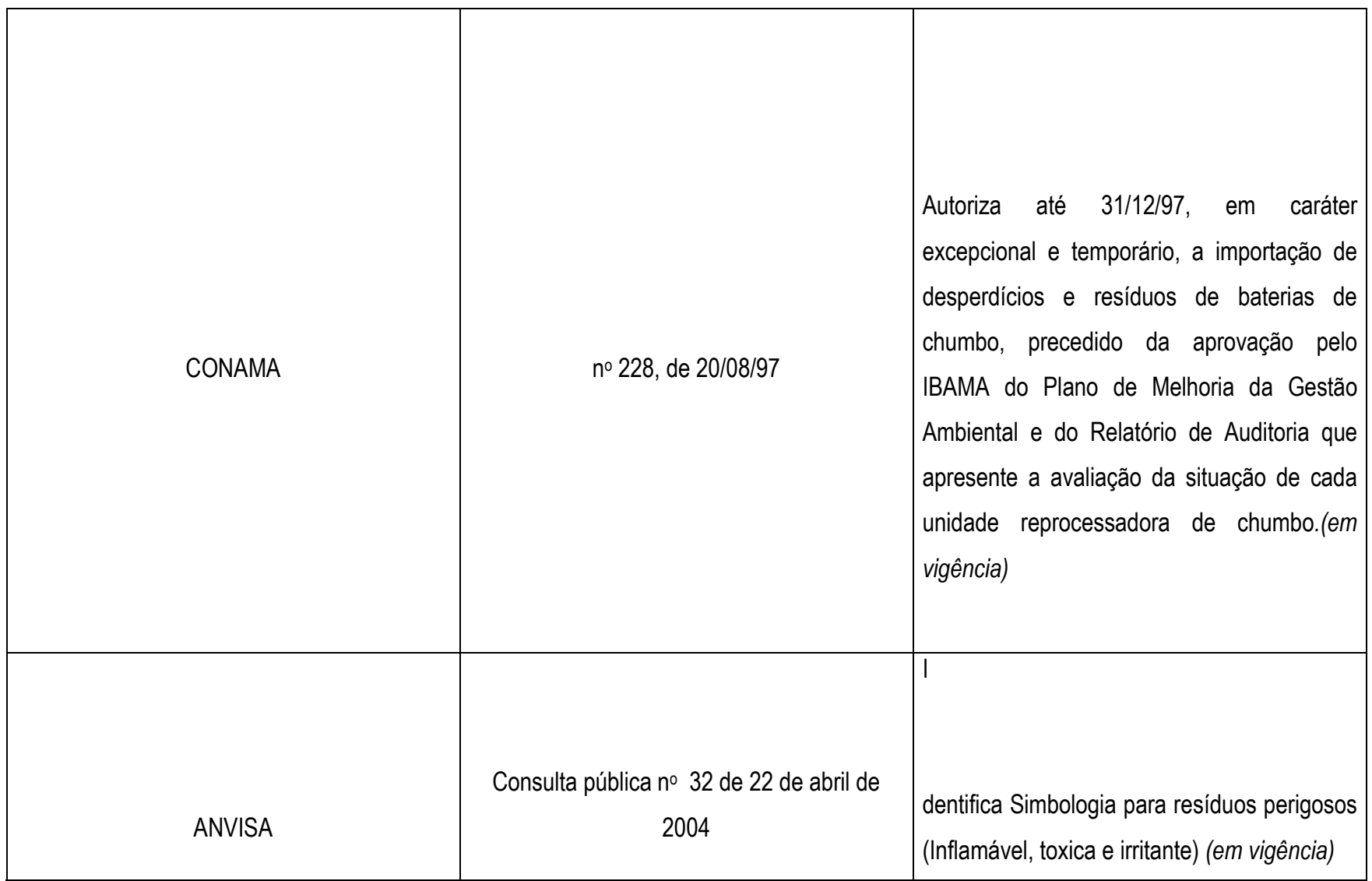

Organização: Luciana Ziglio e Lucy Lerner Fonte: Implementação das Convenções Multilaterais no Brasil, MMA, 2005.www.mma.gov.br. Acesso em 28.03.2005.

www.conama.gov.br Acesso em 28.03.2005.

www.planalto.gov.br Acesso em 28.03.2005. e Diários oficiais da União 
Leis Vigentes no Brasil referentes a Resíduos Industriais (continua).

\begin{tabular}{|c|c|c|}
\hline Lei Federal & 5.357 de 17.11.1967. & $\begin{array}{l}\text { Estabelece penalidades para embarcações e } \\
\text { terminais marítimos ou fluviais que lançarem } \\
\text { detritos ou óleo em águas brasileiras, entre } \\
\text { outras providências. (Revogada pela Lei } n \\
9966 \text { de } 28 / 04 / 00 \text { ) }\end{array}$ \\
\hline Decreto & 73.030 de 30.10 .1973 & $\begin{array}{l}\text { Dispõe sobre o destino e tratamento } \\
\text { de resíduos (revogado) }\end{array}$ \\
\hline Decreto lei & 1413 de 14.08 .75 . & $\begin{array}{l}\text { Dispõe sobre o controle da poluição } \\
\text { provocada pelas atividades } \\
\text { industriais. (em vigência) }\end{array}$ \\
\hline $\begin{array}{l}\text { Portaria da Secretaria Especial } \\
\text { de Meio Ambiente }\end{array}$ & 03 de 19.01.77. & $\begin{array}{l}\text { Estabelece normas que obrigam as } \\
\text { empresas instaladas ou a se } \\
\text { instalarem em território nacional para } \\
\text { prevenir ou corrigir os inconvenientes } \\
\text { e prejuízos provenientes da poluição } \\
\text { e contaminação do meio } \\
\text { ambiente.(em vigência) }\end{array}$ \\
\hline
\end{tabular}


Leis Vigentes no Brasil referentes a Resíduos Industriais (continua).

\begin{tabular}{|c|c|c|}
\hline Lei Federal & 6803 de 02.07.80. & $\begin{array}{l}\text { Estabelece as diretrizes básicas para } \\
\text { o zoneamento industrial em áreas } \\
\text { criticas quanto à poluição ambiental. } \\
\text { (em vigência) }\end{array}$ \\
\hline Portaria & 019 de 20.01. 82. & $\begin{array}{l}\text { Proíbe a produção, uso e } \\
\text { comercialização de Bifelinas } \\
\text { Policloradas (PCBs). (revogada pela } \\
\text { resolução CONAMA } 23 \text { de 12/96) }\end{array}$ \\
\hline Lei Federal & 7.802 de 11.07.89. & $\begin{array}{l}\text { Regulamenta desde a pesquisa e } \\
\text { fabricação dos agrotóxicos até sua } \\
\text { comercialização, aplicação, controle, } \\
\text { fiscalização e também o destino da } \\
\text { embalagem. (em vigência e } \\
\text { Regulamentada pelo Decreto } 4.074 \text { de } \\
\text { 04/01/2002) }\end{array}$ \\
\hline Portaria Ministerial & 261/MT, de 11.04.1989. & $\begin{array}{l}\text { Promove ajustamentos técnico- } \\
\text { operacionais no Regulamento para o } \\
\text { Transporte Rodoviário de Produtos } \\
\text { Perigosos. (Substituída pela Resolução } \\
\text { 204/ANTT de 12/02/2004 (DOU } \\
\text { 31/05/2004). }\end{array}$ \\
\hline Portaria INMETRO & 221, de 30.09.1991. & $\begin{array}{l}\text { Aprova o Regulamento Técnico "Inspeção } \\
\text { em equipamentos destinados ao transporte } \\
\text { de produtos perigosos a granel não incluídos } \\
\text { em outros regulamentos" - RT-27."(em } \\
\text { vigência)". }\end{array}$ \\
\hline
\end{tabular}


Leis Vigentes no Brasil referentes a Resíduos Industriais (conclusão)

\begin{tabular}{|c|c|c|}
\hline Lei Federal & 9.055 de 01.06.95. & $\begin{array}{l}\text { Limita a extração, industrialização, utilização } \\
\text { e comercialização, transporte de asbesto e } \\
\text { amianto e sua importação poderá ocorrer } \\
\text { apenas mediante aprovação do DNPM. } \\
\text { (Regulamentada pelo Decreto } 2.350 \text { de } \\
\text { 15/10/95 em vigência) }\end{array}$ \\
\hline Portaria do Ministério do Interior & 204 de 1997. & $\begin{array}{l}\text { Regulamenta o transporte federal } \\
\text { rodoviário de produtos perigosos. } \\
\text { Substituída pela Resolução n } \\
204 / \text { ANTT de 12/02/2004 (DOU } \\
\text { 31/05/2004). }\end{array}$ \\
\hline Portaria & 1.469 de 29.12 .2000 . & $\begin{array}{l}\text { Estabelece procedimentos para aferir } \\
\text { a contaminação do solo e de águas } \\
\text { subterrâneas decorrentes de } \\
\text { atividades industriais. (em vigência) }\end{array}$ \\
\hline
\end{tabular}

Organização: Luciana Ziglio e Lucy Lerner

Fontes : www.mma.gov.br. Acesso em 28.03.2005.

www.conama.gov.br Acesso em 28.03.2005.

www.planalto.gov.br Acesso em 28.03.2005.

Diários oficiais da União nas próprias legislações mencionadas 
Resoluções do Conselho Nacional de Meio Ambiente referente a Resíduos Industriais (continua)

\begin{tabular}{|c|c|}
\hline 001-A de 23.01.86. & $\begin{array}{l}\text { Regulamenta o transporte de cargas perigosas conforme } \\
\text { decreto } 88.821 \text { de } 06.10 .83 \text {. (em vigência) }\end{array}$ \\
\hline 026 de 03.12.86. & $\begin{array}{l}\text { Cria as câmaras técnicas de recursos hídricos, de } \\
\text { poluição industrial, de mineração, flora e fauna e } \\
\text { agrotóxicos. (em vigência) }\end{array}$ \\
\hline 006 de 15.06.88. & $\begin{array}{l}\text { Obriga as indústrias geradoras de resíduos, conforme os } \\
\text { respectivos critérios, apresentar ao órgão ambiental } \\
\text { competente informações sobre a geração, características } \\
\text { e destino final de seus resíduos. (em vigência) }\end{array}$ \\
\hline 013 de 14.09.89. & $\begin{array}{l}\text { Acrescenta a câmara técnica de acompanhamento e } \\
\text { análise das soluções propostas para destino final do lixo } \\
\text { radioativo produzido do país da respectiva competência. } \\
\text { (em vigência) }\end{array}$ \\
\hline 008 de 19.09.91. & $\begin{array}{l}\text { Veta a entrada de materiais residuais destinados a } \\
\text { disposição final e incineração no país. (em vigência) }\end{array}$ \\
\hline 005 de 05.08.93. & $\begin{array}{l}\text { Dispõe sobre resíduos sólidos gerados em hospitais, } \\
\text { portos e aeroportos. (em vigência) }\end{array}$ \\
\hline 009 de 31.08.93. & Dispõe sobre óleos usados. (em vigência) \\
\hline
\end{tabular}


Resoluções do Conselho Nacional de Meio Ambiente referente a Resíduos Industriais (conclusão)

\begin{tabular}{|c|c|}
\hline 019 de 29.09.94. & $\begin{array}{l}\text { Autoriza, excepcionalmente, a exportação de resíduos } \\
\text { perigosos contendo bifenilas policloradas - PCBs. }\end{array}$ \\
\hline 013 de 13.12.95. & $\begin{array}{l}\text { Estabelece que toda empresa que produza, importe, } \\
\text { exporte, comercialize ou utilize substâncias controladas, } \\
\text { deverá estar cadastrada junto ao IBAMA. (Revogada } \\
\text { pela resolução CONAMA n } 267 \text { de 14/09/00) }\end{array}$ \\
\hline 228 de 20.08.97. & $\begin{array}{l}\text { Autoriza até 31/12/1997, em caráter excepcional, a } \\
\text { importação de resíduos de acumuladores elétricos de } \\
\text { chumbo, observando a legislação internacional vigente } \\
\text { (Convenção de Basiléia). (em vigência) }\end{array}$ \\
\hline 257 de 30.06.99. & $\begin{array}{l}\text { Define critérios de gerenciamento para destino final } \\
\text { ambiental adequado de pilhas e baterias conforme } \\
\text { especifica. (em vigência) }\end{array}$ \\
\hline 258 de 26.08 .99 & $\begin{array}{l}\text { Torna obrigatórias as empresas fabricantes e importadoras de } \\
\text { pneumáticos coletar e dar destino final ambiental adequado aos } \\
\text { pneus inservíveis no país. (em vigência) }\end{array}$ \\
\hline 264 de 26.08 .99 & $\begin{array}{l}\text { Trata do licenciamento de fornos rotativos de produção de clínquer } \\
\text { para atividades de co-processamento de resíduos, excetuando-se os } \\
\text { resíduos domiciliares brutos, os de serviços de saúde, os } \\
\text { radioativos, explosivos, organoclorados, agrotóxicos e afins. (em } \\
\text { vigência) }\end{array}$ \\
\hline
\end{tabular}

Organização: Luciana Ziglio e Lucy Lerner. Fontes : www.mma.gov.br. Acesso em 28.03.2005.

www.conama.gov.br Acesso em 28.03.2005. www.planalto.gov.br Acesso em 28.03.2005. e Diários oficiais da União nas próprias legislações mencionadas 
Normas da Associação Brasileira Técnica referentes a Resíduos Industriais.

\begin{tabular}{|c|c|}
\hline 7500 de 2000. & $\begin{array}{l}\text { Simbologia de risco e manuseio para o transporte e } \\
\text { armazenamento de materiais. }\end{array}$ \\
\hline 7501 de 1989. & Terminologia para o transporte de produtos perigosos. \\
\hline 7503 de 2000. & $\begin{array}{l}\text { Ficha de emergência para o transporte de produtos } \\
\text { perigosos - características e dimensões. }\end{array}$ \\
\hline 7504 de 1999. & $\begin{array}{l}\text { Envelope para o transporte de resíduos perigosos - } \\
\text { características e dimensões. }\end{array}$ \\
\hline 8285 de 2000. & $\begin{array}{l}\text { Preenchimento da ficha de emergência para o transporte } \\
\text { de produtos perigosos. }\end{array}$ \\
\hline 8286 de 2000. & $\begin{array}{l}\text { Emprego da sinalização nas unidades de transporte e de } \\
\text { rótulos nas embalagens de produtos perigosos. }\end{array}$ \\
\hline 9734 de 2000. & $\begin{array}{l}\text { Conjunto de equipamentos de proteção individual para } \\
\text { avaliação de emergência e fuga no transporte rodoviário } \\
\text { de produtos perigosos. }\end{array}$ \\
\hline 9735 de 2000. & $\begin{array}{l}\text { Conjunto de equipamentos necessários para } \\
\text { emergências no transporte rodoviário de produtos } \\
\text { perigosos. }\end{array}$ \\
\hline 12710 de 2000 . & $\begin{array}{l}\text { Proteção contra incêndio por extintores no transporte } \\
\text { rodoviário de produtos perigosos. }\end{array}$ \\
\hline 13095 de 2000. & $\begin{array}{l}\text { Instalação e fixação de extintores, no transporte } \\
\text { rodoviário de produtos perigosos. }\end{array}$ \\
\hline 13221 de 2000 . & Transporte de resíduos. \\
\hline 14619 de 2000. & $\begin{array}{l}\text { Transporte de produtos perigosos - Incompatibilidade } \\
\text { química. }\end{array}$ \\
\hline 10.004 de 2004. & Classificação dos resíduos. \\
\hline 10.005 de 2004 . & Métodos de lixiviação. \\
\hline 10.006 de 2004. & Procedimento para obtenção de extrato solubilizado. \\
\hline 10.007 de 2004. & Classificação dos resíduos. \\
\hline
\end{tabular}

Fonte: Normas da Associação Brasileira de Normas Técnicas. Organização: Luciana Ziglio . Todas as normas estão em vigor. 
